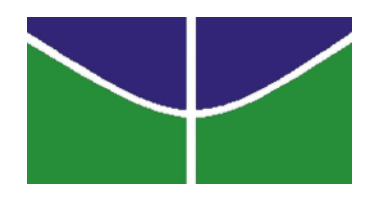

UNIVERSIDADE DE BRASÍLIA INSTITUTO DE CIÊNCIAS HUMANAS

DEPARTAMENTO DE GEOGRAFIA

PROGRAMA DE PÓS-GRADUAÇÃO EM GEOGRAFIA

LABORATÓRIO DE SISTEMAS DE INFORMAÇÕES ESPACIAIS

ANÁLISE DA DINÂMICA DA PRODUÇÃO DE SOJA, CANA DE AÇÚCAR, MILHO E BOVINA NO TERRITÓRIO BRASILEIRO.

REBECCA LIMA ALBUQUERQUE MARANHÃO

ORIENTADOR: PROF. RENATO FONTES GUIMARÃES

DISSERTAÇÃO DE MESTRADO

BRASÍLIA

DEZEMBRO/2015 


\author{
UNIVERSIDADE DE BRASÍLIA \\ INSTITUTO DE CIÊNCIAS HUMANAS \\ DEPARTAMENTO DE GEOGRAFIA \\ PROGRAMA DE PÓS-GRADUAÇÃO EM GEOGRAFIA \\ LABORATÓRIO DE SISTEMAS DE INFORMAÇÕES ESPACIAIS
}

\title{
ANÁLISE DA DINÂMICA DA PRODUÇÃO DE SOJA, CANA DE AÇÚCAR, MILHO E BOVINA NO TERRITÓRIO BRASILEIRO.
}

\section{REBECCA LIMA A. MARANHÃO}

Dissertação de Mestrado aprovada como requisito parcial para obtenção de grau de mestre em Geografia, na Universidade de Brasília, pela Banca Examinadora, constituída por:

Renato Fontes Guimarães, Doutor - Universidade de Brasília

(Orientador)

Concepta Margaret Mcmanus Pimentel, Doutora - Universidade de Brasília (Coorientadora)

Osmar Abílio de Carvalho Júnior, Doutor - Universidade de Brasília (Examinador Interno)

Carla Bernadete Madureira Cruz, Doutora - Universidade Federal do Rio de Janeiro (Examinador Externo)

José Eustáquio Ribeiro Vieira Filho, Doutor - Instituto de Pesquisa Econômica Aplicada - IPEA

(Examinador Externo)

Brasília, 08 de dezembro de 2015. 
FICHA CATALOGRÁFICA

MARANHÃO, REBECCA LIMA ALBUQUERQUE

ANÁLISE DA DINÂMICA DA PRODUÇÃO DE SOJA, CANA DE AÇÚCAR, MILHO E BOVINA NO TERRITÓRIO BRASILEIRO.

(UNB/IH/LSIE, Mestrado, Geoprocessamento, 2015).

1. Produção Agropecuária Brasileira 2. SIG 3. Soja

4. Cana de Açúcar 5. Milho 6. Bovino

I. UnB/ IH/ GEA

Dissertação de Mestrado - Universidade de Brasília, Departamento de Geografia.

\section{REFERENCIA BIBLIOGRÁFICA}

MARANHÃO, R.L.A. Análise da dinâmica da produção de soja, cana de açúcar, milho e bovina no território brasileiro. (Dissertação de mestrado), Curso de PósGraduação em Geografia, Universidade de Brasília, 2015.

\section{CESSÃO DE DIREITOS}

NOME DO AUTOR: Rebecca Lima Albuquerque Maranhão

TÍTULO DA DISSERTAÇÃO: Análise da dinâmica da produção de soja, cana de açúcar, milho e bovina no território brasileiro. GRAU/ ANO: 2015.

É cedida a Universidade de Brasília permissão para reproduzir cópias desta dissertação e emprestar ou vender tais cópias somente para propósitos acadêmicos e científicos. $\mathrm{O}$ autor reserva outros direitos de publicação e nenhuma parte desta dissertação de mestrado pode ser reproduzida sem a permissão do autor.

Rebecca Lima Albuquerque Maranhão 


\section{AGRADECIMENTOS}

Agradeço ao meu orientador, professor Dr. Renato Fontes Guimarães pela experiência e conhecimento compartilhado; muito obrigada pela paciência e o incentivo que foram fundamentais em todas as fases desse trabalho, acredito que este é um passo importante na minha vida acadêmica e sou muito grata. Também agradeço ao professor Dr. Osmar Abílio de Carvalho Júnior por contribuir igualmente com todo o saber e auxílio.

Obrigada à professora Dra. Concepta McManus Pimentel que colaborou para que o trabalho fosse elaborado. Agradeço também aos professores e pesquisadores Dra. Carla Bernadete Madureira Cruz, Dr. José Eustáquio Ribeiro Vieira Filho pela disponibilidade em participar da banca de defesa da dissertação.

Obrigada à minha família por toda força, apoio e paciência durante esse longo desafio, em especial à minha mãe Silvia Santos Lima, meu pai Luiz Carlos Albuquerque Maranhão e minha irmã Maria Cristina Lima Albuquerque Maranhão. Agradeço aos grandes amigos e parceiros de estudos Jonathan Vinagre, Ricardo Aranha, Nathalia da Silva Costa e também Ana Laura pela troca de conhecimento e ajuda mútua. 


\section{RESUMO}

O Brasil é um dos maiores produtores e exportadores de alimentos do mundo. Sua alta produtividade é resultado de uma série de políticas favoráveis ao comércio agrícola, assim como investimentos em pesquisa e desenvolvimento. $\mathrm{O}$ aumento da produção tem contribuído como incentivo para a expansão das fronteiras agrícolas causando mudanças substanciais no uso e cobertura do solo do país. Essas modificações afetam tanto diretamente quanto indiretamente o desmatamento, por meio do deslocamento e substituição das atividades agrícolas. O objetivo do trabalho foi analisar a dinâmica espaço- temporal no território brasileiro de produção bovina no período de 1978 a 2012 e de soja, milho, cana de açúcar no período de 1993 a 2012. Foram utilizados dados municipais de produção provenientes do Instituto Brasileiro de Geografia e EstatísticaIBGE. A partir das séries temporais foram calculadas as taxas de crescimento e de aceleração para cada produção, assim como o direcionamento das produções no território brasileiro e a correlação entre a produção bovina e de cana de açúcar e da produção bovina e de soja entre o período de 1993 a 2012 para verificar se o aumento de uma produção acarretou a diminuição da outra. Os resultados mostraram alta taxa de crescimento e aceleração da produção de soja e milho, nas regiões Sul, Centro-Oeste e parcela do oeste do Nordeste, ambas as produções apresentaram deslocamento para a porção norte do país. A região Centro-Sul apresentou alta taxa de crescimento e aceleração do crescimento da produção de cana de açúcar e também foi observado o deslocamento da produção de cana de açúcar da região Nordeste para a porção CentroSul, apontando a perda da participação da região Nordeste ao longo do período analisado. Enquanto isso, nos mapas recentes da produção bovina os municípios na região da Amazônia Legal apresentaram alta taxa de crescimento e aceleração do crescimento da produção. A metodologia utilizada mostrou-se eficiente na análise multitemporal da produção de cana de açúcar, milho, soja e bovina, facilitando o maior entendimento da dinâmica dessas produções no Brasil, que pode ser utilizada como subsídio às políticas públicas nessa área. $\mathrm{Na}$ análise da correlação inversa entre a produção bovina e a produção de cana de açúcar entre 2002 e 2010, os municípios que se destacaram foram os da região Centro-Sul, além disso, a maioria dos municípios que apresentaram aumento da produção de cana de açúcar e diminuição da produção bovina estava também nessa região. A análise da correlação inversa entre a produção de soja e a produção bovina apontou principalmente os municípios do Centro-Oeste, Sudeste e 
Sul do país. Durante o período de 2003 a 2012, os municípios que apresentaram o aumento da produção de soja e diminuição da produção bovina estavam também nessas regiões. A entrada de carros flexfuel no mercado brasileiro em 2003 e a alta de preços das commodities no mercado internacional podem explicar a recente diminuição da produção bovina no Centro-Oeste, Sul, Sudeste levado pelo aumento da produção de soja e cana de açúcar nessas mesmas regiões deslocando a produção bovina para porções mais ao norte do país, como foi apontado no mapa do ponto médio da produção bovina. A análise também mostrou que são complexas as causas motores do deslocamento destas produções no território brasileiro, que podem estar ligadas a razões climáticas, topográficas, de acesso ao crédito e assistência técnica, e também por questões de mercado. São indispensáveis políticas públicas de longo prazo que abordem de forma integrada essas dinâmicas para conduzir as mudanças em direção a práticas sustentáveis de intensificação de uso do solo, levando em consideração as desigualdades regionais e promovendo a ciência e a inovação na agropecuária brasileira.

Palavras- Chave: Produção Agropecuária Brasileira, SIG, Soja, Cana de Açúcar, Milho, Bovinos. 


\section{ABSTRACT}

Brazil is one of the largest producers and exporters of food in the world. Its high productivity is the result of a series of favorable agricultural trade policies and investments in research and development. Increased production has contributed as an incentive for the expansion of the agricultural frontier causing substantial changes in land use and land cover in the country. These changes affect both directly and indirectly deforestation, through the displacement and replacement of agricultural activities. The main objective in this study was to analyze the spatial-temporal dynamic in Brazil's cattle production during 1978-2012 and soybeans, corn, sugarcane from 1993 to 2012. Municipal production data were used from the Brazilian Institute of Geography and Statistics. From temporal series were calculated growth rates and acceleration for each production, as well as the direction of the productions in Brazil and the correlation between cattle and sugar cane production and cattle and soy production from 1993 to 2012 to verify if the increase of a production entails the reduction of other. The results showed high growth rate and acceleration of soybeans and corn production in the South, Midwest and the western side of the Northeast region, both productions presented are moving to the northeast side of the country. The South-Central region achieved high growth rates and acceleration of sugarcane production, also was observed the displacement of sugarcane production from the Northeast region to the South-Central region, indicating the loss of participation in the Northeast over the analysis period. Meanwhile, in the recent period from 2003 to 2012, the maps of cattle production highlighted high growth rate and acceleration of production in the Legal Amazon area. The methodology used was efficient in multi-temporal analysis of sugarcane, corn, soybeans and cattle production, promoting the understanding of the dynamics of the productions in Brazil, which can be used as a subsidy to public policies. The inverse correlation analysis between cattle production and sugarcane production from 2002 to 2012 indicated municipalities in the South-Central, moreover, most of the municipalities that showed an increase in sugarcane production and decreased in cattle production was in this region. The analysis of the inverse correlation between the production of soy and beef production indicated mainly to municipalities in the Midwest, Southeast and South. During the period from 2003 to 2012, the municipalities that displayed an increase in soybean production and reduced beef production were also in these regions. The entry of flex-fuel cars in brazilian market in 2003 and the rise of commodity prices in the 
international market can explain the recent decline in beef production in the Midwest, South, Southeast, led by increased production of soybeans and sugarcane in those regions, shifting beef production to areas further north, as it was indicated in the midpoint map of bovine production. The analysis also displayed that the causes of displacement of these productions are complex, which may be linked to climatic, topographical reasons, access to credit and technical assistance and market issues. Long-term public policies are necessary to understand these dynamics in an integrated management to lead to improvements toward sustainable practices intensification of land use, taking into account regional disparities and promoting science and innovation in Brazilian agriculture.

Keywords: Brazilian Agricultural Production, GIS, Soybeans, Sugarcane, Maize, Cattle. 


\section{ÍNDICE DE FIGURAS}

Figura 1. Biomas brasileiros

Figura 2. Procedimento para a elaboração dos mapas da taxa de crescimento e aceleração de produção bovina.

Figura 3. Metodologia da elaboração dos mapas da taxa de crescimento e aceleração do crescimento de produção de cana de açúcar, milho e soja.

Figura 4. Janela móvel de 5 anos da produção bovina, de cana de açúcar e soja, que transcorre a sobre a série temporal (de 1993 a 1997, de 1994 a 1998, de 1995 a 1999, de 1996 a 2000,...de 2008 a 2012) para a análise de correlação.

Figura 5. Produção bovina (em mil cabeças). (a) 1978-1987; (b)1983-1992; (c) 19881997; (d) 1992-2002; (e) 1998-2007; (f) 2003-2012.

Figura 6. Produção de cana de açúcar (em mil toneladas). (a) 1993-2002; (b) 1997 2008; (c) 2003-2012.

Figura 7. Produção de cana de açúcar (em mil toneladas). (a) 1993- 2002; (b) 1997 2008; (c) 2003-2012.

Figura 8. Produção de milho (em mil toneladas) para os seguintes períodos: (a) 19932002; (b) 1997-2008; (c) 2003-2012.

Figura 9. Mapas da taxa de crescimento de produção bovina a partir dos dados absolutos da produção para os seguintes períodos: (a) 1978-1987; (b)1983-1992; (c) 1988-1997; (d) 1992-2002; (e) 1998-2007 e (f) 2003-2012 a partir de dados absolutos da produção.

Figura 10. Mapa da taxa média de crescimento da produção bovina no período 19782012 a partir dos dados absolutos da produção.

Figura 11. Mapas das taxas de crescimento de produção bovina a partir dos dados normalizados nos seguintes períodos: (a) 1978-1987; (b)1983-1992; (c) 1988-1997; (d) 1992-2002; (e) 1998-2007; (f) 2003- 2012 a partir de dados normalizados da produção.

Figura 12. Mapa da taxa média de crescimento de produção bovina no período 19782012 a partir de dados normalizados da produção.

Figura 13. Taxa de crescimento da produção de cana de açúcar a partir de dados absolutos da produção para os seguintes períodos: (a) 1993-2002; (b) 1998-2007; (c) 2003-2012; e (d) média da taxa do crescimento da produção de cana de açúcar durante o período 1993-2012 a partir de dados absolutos da produção.

Figura 14. Taxa de crescimento da produção de cana de açúcar a partir de dados normalizados da produção para os seguintes períodos: (a) 1993-2002; (b) 1998-2007; (c) 2003-2012; e (d) média da taxa do crescimento da produção de cana de açúcar durante o período 1993-2012 a partir de dados normalizados da produção.

Figura 15. Taxa de crescimento de produção de soja a partir de dados absolutos da produção para os seguintes períodos: (a) 1993-2002; (b) 1998-2007; (c) 2003-2012; e (d) média da taxa de crescimento de produção de soja durante o período 1993-2012 a partir de dados absolutos da produção.

Figura 16. Taxa de crescimento de produção de soja a partir de dados normalizados da produção para os seguintes períodos: (a) 1993-2002; (b) 1997-2008; (c) 2003-2012; e 
(d) média taxa de crescimento de produção de soja durante o período 1993-2012 a partir de dados normalizados da produção.

Figura 17. Taxa de crescimento de produção de milho a partir dos dados absolutos da produção para os seguintes períodos: (a) 1993-2002; (b) 1997-2008; e (c) 2003-2012; e (d) média da taxa de crescimento de produção de milho durante o período de 1993 a 2012 a partir de dados absolutos da produção.

Figura 18. Taxa de crescimento de produção de milho a partir dos dados normalizados da produção para os seguintes períodos: (a) 1993- 2002; (b) 1997-2008; e (c) 20032012; e (d) média da taxa de crescimento de produção de milho durante o período de 1993 a 2012 a partir de dados normalizados da produção.

Figura 19. Mapas de aceleração da produção bovina a partir de dados absolutos nos seguintes períodos: (a) 1978-1992; (b) 1988-1997; (c) 1993-2002; (d) 1998-2007; (e) 2003-2012; e (f) aceleração média da produção bovina durante o período 1978-2012 a partir de dados absolutos.

Figura 20. Mapas de aceleração da produção bovina a partir de dados normalizados para os seguintes períodos: (a) 1978-1992; (b) 1988-1997; (c) 1993-2002; (d) 19982007; (e) 2003-2012; e (f) aceleração média de produção bovina durante o período 1978-2012 a partir dos dados normalizados da produção.

Figura 21. Mapas de aceleração de produção de cana de açúcar a partir dos dados absolutos para os seguintes períodos: (a) 1993-2007; (b) 2003-2012; e (c) aceleração média da produção de cana de açúcar durante o período 1993-2012 a partir de dados absolutos.

Figura 22. Mapas de aceleração de produção de cana de açúcar a partir de dados normalizados para os períodos de (a) 1993-2007; (b) 2003-2012; e (c) aceleração média da produção de cana de açúcar durante o período 1993-2012 a partir de dados normalizados

Figura 23. Mapa de aceleração da produção de soja a partir dos dados absolutos da produção: (a) 1993 - 2007; (b) 2003 - 2012; e (c) aceleração média da produção de soja durante o período 1993-2012 a partir de dados absolutos.

Figura 24. Mapa de aceleração de produção de soja durante o período de 1993 a 2012 a partir dos dados normalizados da produção. (a) 1993- 2007; (b) 2003-2012; e (c) aceleração média da produção de soja durante o período de 1993 -2012 a partir de dados normalizados

Figura 25. Mapas de aceleração da produção de milho a partir dos dados absolutos da produção: (a) 1993-2007; (b) 2003-2012; e (c) aceleração média da produção de milho durante o período 1993-2012 a partir de dados absolutos.

Figura 26. Mapa de aceleração da produção de milho a partir dos dados normalizados da produção. (a) 1993-2007; (b) 2003-2012; (c) aceleração média da produção de milho durante o período 1993-2012 a partir de dados normalizados.

Figura 27. Mapas do ponto médio espacial das produções. (a) Ponto médio da produção bovina de 1978- 2012; (b) Ponto médio da produção de cana de açúcar de 1990-2012; (c) Ponto médio da produção de soja de 1990-2012; (d) Ponto médio da produção de milho de 1990-2012. 
Figura 28. Detalhe do ponto médio espacial das produções. (a) Ponto médio da produção bovina de 1978- 2012; (b) Ponto médio da produção de cana de açúcar de 1990-2012; (c) Ponto médio da produção de soja de 1990-2012; (d) Ponto médio da produção de milho de 1990-2012.

Figura 29. Correlação inversa entre a produção bovina e a produção de cana de açúcar. (a) 1993-1997; (b) 1994-1998; (c) 1995-1999; (d) 1996-2000; (e) 1997-2001; (f) 19982002.

Figura 30. Correlação inversa entre a produção bovina e a produção de cana de açúcar. (g) 1999-2003; (h) 2000-2004; (i) 2001-2005; (j) 2002-2006; (k) 2003-2007; (1) 20042008.

Figura 31. Correlação inversa entre a produção bovina e a produção de cana de açúcar. (m) 2005-2009; (n) 2006-2010; (o) 2007-2011; (p) 2008-2012.

Figura 32. Correlação inversa destacando o aumento da produção bovina e a diminuição da produção de cana de açúcar. (a) 2003-2007; (b) 2004-2008; (c) 20052009; (d) 2006-2010; (e) 2007-2011; (f) 2008-2012.

Figura 33. Correlação inversa destacando o aumento da produção de cana de açúcar e a diminuição da produção bovina. (a) 2003-2007; (b) 2004-2008; (c) 2005-2009; (d) 2006-2010; (e) 2007-2011; (f) 2008-2012

Figura 34. Correlação inversa entre a produção bovina e a produção de soja. (a) 1993 1997; (b) 1994- 1998; (c) 1995-1999; (d) 1996-2000; (e) 1997-2001; (f) 1998-2002... 84 Figura 35. Correlação inversa entre a produção bovina e produção de soja. (g) 1999 2003; (h) 2000 -2004; (i) 2001-2005; (j) 2002-2006; (k) 2003-2007; (l) 2004-2008.... 85 Figura 36. Correlação inversa entre a produção bovina e a produção de soja. (m) 2005 2009; (n) 2006 -2010; (o) 2007-2011; (p) 2008-2012.

Figura 37. Correlação inversa destacando o aumento da produção bovina e a diminuição da produção de soja. (a) 2003-2007; (b) 2004-2008; (c) 2005-2009; (d) 2006 -2010; (e) 2007-2011; (f) 2008-2012

Figura 38. Correlação inversa destacando o aumento da produção de soja e a diminuição da produção bovina. (a) 2003-2007; (b) 2004-2008; (c) 2005-2009; (d) 2006 -2010; (e) 2007-2011; (f) 2008-2012. 88 


\section{SUMÁRIO}

RESUMO

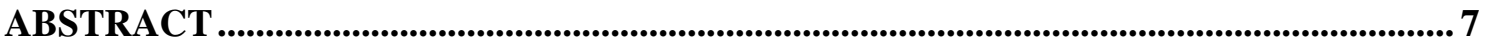

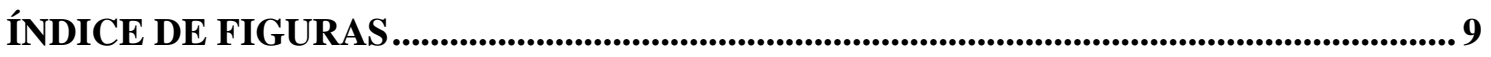

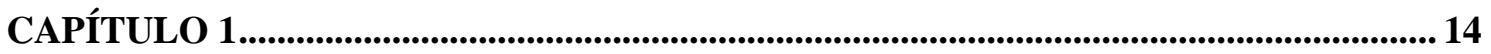

INTRODUÇÃO ................................................................................................................................. 14

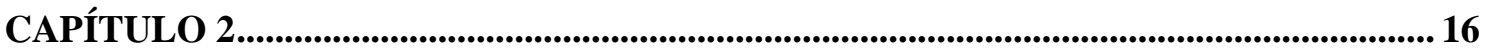

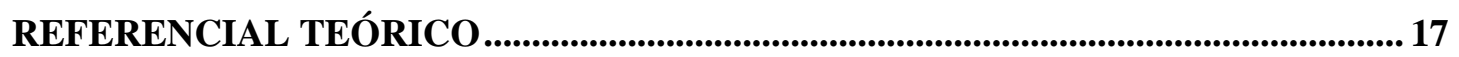

2.1 INDUSTRIALIZAÇÃO E MODERNIZAÇÃO DA AGRICULTURA ....................... 17

2.2 O DESEMPENHO DA AGROPECUÁRIA NOS ANOS 80 E 90................................ 20

2.3 O COMPORTAMENTO RECENTE DA AGROPECUÁRIA BRASILEIRA E AS PRINCIPAIS POLÍTICAS PÚBLICAS PARA O SETOR............................................ 21

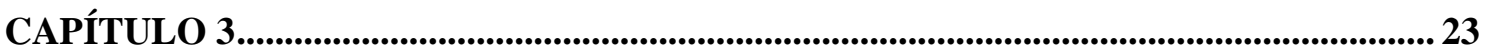

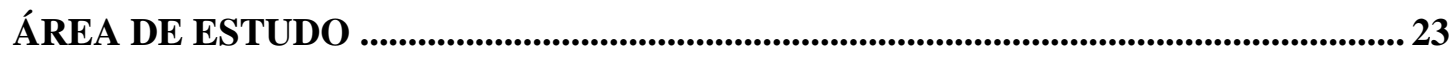

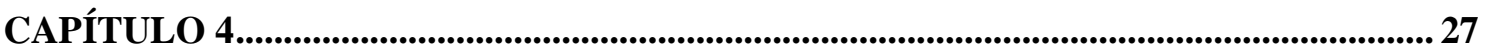

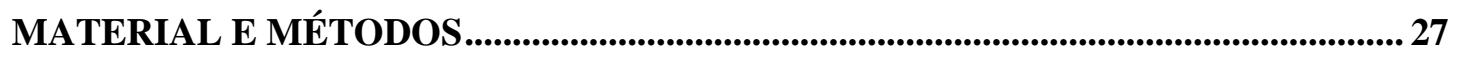

4.1 Séries temporais da produção agrícola e bovina .................................................................... 27

4.2 Espacialização de produções agrícolas e bovinas e de suas taxas de crescimento e aceleração ................................................................................................................................................ 27

4.3 Análise temporal do ponto médio espacial de produção agrícola e bovina.......................... 29

4.4 Análise de correlação de séries temporais de produções agrícolas e bovinas ...................... 29

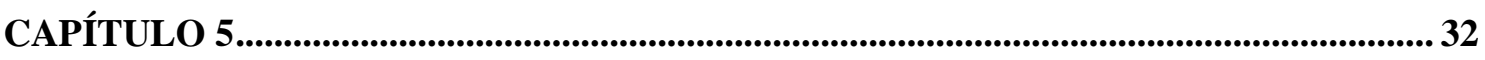

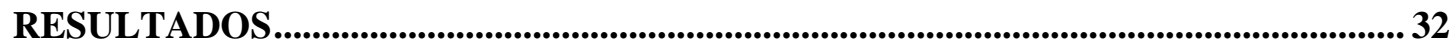

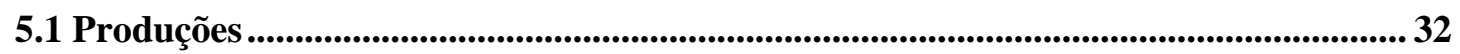

5.1.1 Produção Bovina (1978 - 2012) ........................................................................................ 32

5.1.2 Produção de Cana de Açúcar (1993 - 2012)........................................................................ 34

5.1.3 Produção de Soja (1993 - 2012) ............................................................................................36

5.1.4 Produção de Milho (1993 - 2012) ............................................................................................... 38

5.2 Taxa de Crescimento das Produções ........................................................................................ 40

5.2.1 Taxa de Crescimento de Produção Bovina (1978 - 2012)............................................... 40

5.2.2 Taxa de Crescimento da Produção de Cana de Açúcar (1993 - 2012)........................... 46

5.2.3 Taxa de Crescimento de Produção de Soja (1993 - 2012) ...............................................50

5.2.4. Taxa de Crescimento de Produção de Milho (1993 - 2012)........................................ 54

5.3 Mapas de Aceleração da Produção................................................................................................. 58 
5.3.1 Mapas de Aceleração da Produção Bovina (1978 - 2012) ................................................ 58

5.3.2. Mapas de Aceleração da Produção de Cana de Açúcar $(1993$ - 2012)......................... 62

5.3.3. Mapas de Aceleração da Produção de Soja (1993 - 2012)............................................. 65

5.3.4. Mapas de Aceleração da Produção de Milho (1993 - 2012) .......................................... 68

5.4 Ponto Médio Espacial das Produções .......................................................................................... 71

5.5. Correlação Inversa das Produções ............................................................................................ 73

5.5.1. Correlação inversa entre a produção bovina e a produção de cana de açúcar durante o período 1993- 2012 .................................................................................................................................. 73

5.5.2 Correlação inversa destacando o aumento da produção bovina e a diminuição da produção de cana de açúcar (2003 - 2012)................................................................................... 73

5.5.3 Correlação inversa destacando a diminuição da produção bovina e aumento da produção de cana de açúcar (2003 - 2012).

5.5.4. Correlação inversa entre a produção bovina e a produção de soja durante o período de 1993 - 2012

5.5.5 Correlação inversa destacando o aumento da produção bovina e redução da produção de soja (2003 - 2012)...................................................................................................................... 82

5.5.6 Correlação inversa destacando a diminuição da produção bovina e aumento da

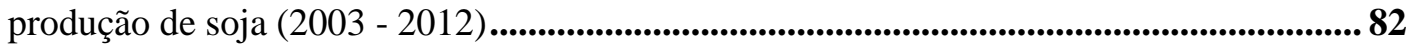

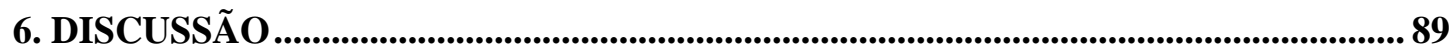

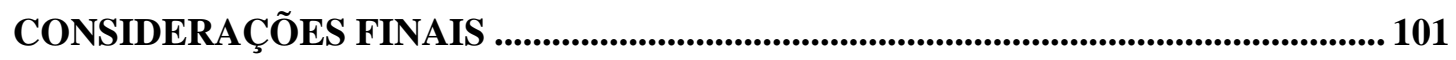

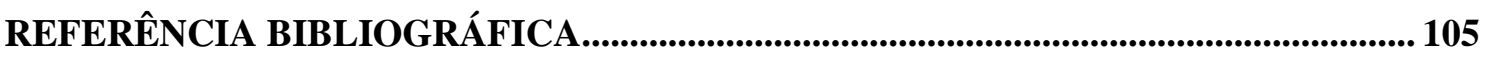




\section{CAPítulO 1}

\section{INTRODUÇÃO}

O Brasil tornou-se um dos líderes globais na economia agrícola, juntamente com os Estados Unidos e a União Européia, devido o grande investimento na agrotecnologia de culturas e do rápido crescimento da demanda por alimentos e estoque de combustível (MARTINELLI et al., 2011). Dessa maneira, nas recentes décadas, as culturas de exportação ocasionaram transformações substanciais no uso e cobertura do solo (BARONA et al., 2010).

O Brasil possui área total de 851 milhões de hectares, dos quais 275 milhões de hectares são destinados à agricultura (FAO, 2011). Em 2011, aproximadamente 196 milhões de hectares foram classificados como área de pastagem, 72 milhões de hectares foram considerados como terras aráveis e 7 milhões de hectares como área de culturas permanentes (FAO, 2011). A soja ocupa a maior parte das áreas de cultivo, cerca de 24 milhões de hectares, seguido por milho (13 milhões de hectares) e cana de açúcar (9 milhões de hectares) (IBGE, 2011). Segundo a FAO (2012), o Brasil é o maior produtor de cana de açúcar, segundo maior produtor de soja e terceiro maior produtor de milho do mundo. Além disso, o país possui o maior rebanho comercial bovino do mundo e é o maior exportador de carne bovina, segundo maior produtor de carne e sexto maior produtor de leite (USDA, 2012).

O país também se destaca por diversificar sua matriz energética, com uma grande participação de fontes renováveis de energia, em que mais de $45 \%$ da energia e $13 \%$ dos combustíveis consumidos em transportes no Brasil são renováveis. Os principais biocombustíveis líquidos utilizados são o etanol e o biodiesel (ANP, 2014). A cana de açúcar é a principal matéria prima para a produção de etanol no país, e 81,37\% da produção de biodiesel são derivados do óleo de soja (CREMONEZ et al., 2015).

$\mathrm{O}$ alto rendimento e a lucratividade dos sistemas agropecuários atuam como incentivo para expansão das fronteiras agrícolas (BYERLEE et., 2014). A ascendência agrícola do país no mercado global é muitas vezes creditada a expansão da produção no Cerrado brasileiro (RADA, 2013). Os principais fatores para o cultivo das commodities neste bioma foram: crédito para produção e comercialização agrícola, política dos 
preços mínimos principalmente durante as décadas de 70 e 80 , investimentos na pesquisa agrícola e na disseminação de novas tecnologias que corrigiu a alta acidez e baixa fertilidade dos solos do Cerrado (ARVOR et al., 2012; CASTRO, 2003). No entanto, este crescimento da agricultura de larga escala tem sido associado com vasta degradação dos ecossistemas brasileiros, principalmente do Cerrado e da Floresta Amazônica, acarretando na consolidação de terras e o agravando da história de desigualdade na distribuição de terras no Brasil (BARONA et al., 2009; MARTINELLI et al., 2010).

O bom desempenho da produção bovina é proveniente da melhoria genética, saúde e nutrição dos animais. Assim como a melhoria na qualidade da forragem, através de melhores valores nutricionais do pasto e de sua melhor gestão. Todos estes fatores acarretaram um crescimento consistente e grande adoção após a década de 80 (MARTHA JÚNIOR et al., 2012).

Estudos recentes mencionam que a expansão da produção de soja e cana de açúcar para produção de biocombustível e ração animal direciona, tanto diretamente quanto indiretamente, a expansão da pecuária extensiva em novas áreas, mais especificamente, na fronteira sul da Floresta Amazônica. (BOWMAN et al., 2012; GOLLNOW e LAKES, 2014; MANN et al., 2014; SCHEFFLER et al., 2011). Todavia, em 2003 entrou em vigor o Plano de Ação para a Prevenção e Controle do Desmatamento na Amazônia Legal (PPCDAM), iniciando a trajetória contínua de redução no desmatamento. Em 2004, 27 mil km² foram desmatados na Amazônia Legal, posteriormente, em 2012 esse valor culminou para uma taxa de $4.656 \mathrm{~km}^{2}$, a menor já registrada pelo PRODES, que realiza o monitoramento por satélites do desmatamento por corte raso na Amazônia Legal (MMA, 2013).

O desmatamento vem diminuindo no Brasil, entretanto ainda há muito que fazer, a maioria das fronteiras dos 60 parques nacionais não é respeitada, ou seja, cabe ao governo sustentar seus decretos através de investimentos em execução e fiscalização. As áreas rurais na Amazônia Legal são abrangentes e a baixa densidade populacional o torna o cumprimento da lei mais difícil. (VERBUG et al.,2014).

O presente trabalho objetiva analisar a dinâmica espaço-temporal no território brasileiro da produção municipal de milho, cana e soja, no período de 1993 a 2012, e da 
produção bovina, no período de 1978 a 2012, determinando a taxa de crescimento (variação percentual) e aceleração de cada produto.

Como objetivos específicos pretende-se avaliar o padrão espacial e direcionamento de cada produção no território brasileiro e também analisar os processos de substituição e associação entre as culturas e a pecuária a partir da análise de correlação entre as séries temporais das produções agropecuárias durante o período de 1993 a 2012. Esta abordagem permite avaliar se os cultivos agrícolas estão substituindo áreas de pecuária, que por sua vez passam a ocupar áreas mais ao norte. 


\section{CAPÍTULO 2}

\section{REFERENCIAL TEÓRICO}

\subsection{INDUSTRIALIZAÇÃO E MODERNIZAÇÃO DA AGRICULTURA}

A partir do período de 1957, o desenvolvimento industrial brasileiro passou a ser prioritariamente promovido por uma política deliberada de industrialização. Essa política consistia essencialmente de uma tarifa aduaneira efetivamente protecionista, um sistema cambial que subsidiava a importação de bens de capital e insumos básicos, e atração do capital estrangeiro por investimento direto (SUZIGAN,1975). A CEPAL (Comissão Econômica para a América Latina) teve papel relevante na formação do pensamento pró-industrialização. A estrutura socioeconômica dos países de periferia onde se encaixava a América Latina apresentava características como: especialização em bens do setor primário e baixa diversidade produtiva, baixa integração aos demais setores econômicos, oferta de mão de obra ilimitada e estrutura institucional pouco inclinada ao investimento e ao progresso técnico. A industrialização seria a saída para superar a pobreza e aproximar economias periféricas das centrais (BIELSCHOWSKY, 2009; CEPAL, 1951a e 1951b; PREBISCH, 1973).

Durante o inicio da década de 50, a expansão da agricultura vinha se fazendo em terras no norte do Paraná (PR), Triângulo Mineiro, sul do Goiás (GO) e do Mato Grosso do Sul (MS), entretanto a produção gerada enfrentava sérias dificuldades de escoamento. A produtividade nessas antigas áreas também não se ampliava e a oferta agrícola para os centros-urbanos acabou tornando-se insuficiente, devido ao intenso processo de migração rural-urbana até o inicio da década de 80. (CARVALHO, 1991; MUELLER, 1992).

Passou-se a notar os efeitos do desincentivo agrícola de determinadas políticas econômicas, tornando-se necessário investir na infraestrutura para viabilizar a expansão de frentes de agricultura comercial nas áreas novas. Originou-se a partir da década de 70, intensa modernização da agropecuária especialmente no Centro-Sul e nas regiões do Cerrado (MUELLER e MARTINE, 1997).

Graziano da Silva (1998) confere à industrialização e à modernização da agricultura as mudanças ocorridas nos espaços rurais, as quais foram trazidas pelo 
processo de urbanização do país e que mudaram as relações do rural com o urbano. A modernização tinha como seus principais elementos o estabelecimento do Sistema Nacional de Crédito Rural (SNCR), fornecendo financiamento abundante, com condições muito generosas para a agricultura comercial, implementação de uma base ampla de pesquisa de agricultura tropical, melhoria dos instrumentos e da administração da política de preços mínimos, incentivos para a formação e expansão de complexos agroindustriais e fortes mudanças nas legislações que regem a reforma agrária (MUELLER e MUELLER, 2006).

O caráter heterogêneo da agricultura foi preservado e até mesmo aprofundado no processo de modernização. Segundo Delgado (2001), pode-se visualizar nele um pacto agrário modernizante e conservador, que, em simultâneo à integração técnica da indústria com a agricultura, trouxe para o seu abrigo as oligarquias rurais ligadas à grande prioridade territorial e ao capital comercial. Hoffman e Kageyama (1985) afirmam que o processo de modernização associou-se a uma melhoria geral dos níveis de renda (aumento da renda média e redução da pobreza absoluta), entretanto tendeu a ampliar a participação relativa das classes que vivem da apropriação do produto excedente, tornando cada vez maior pelo aumento da produtividade decorrente da modernização.

O quadro na época também passou a ser favorável aos produtos de exportação agrícola, em detrimento aos produtos destinados ao mercado interno. Segundo Mueller (1992), a distinção relevante é a registrada entre produtos que são parte de cadeias de verticalização e que recebem intenso apoio governamental, denominados 'modernos' (algodão herbáceo, cana de açúcar, laranja, milho, soja, trigo), e os que ficaram a margem desses processos denominados "tradicionais" (algodão arbóreo, amendoim, banana, batata inglesa, café, feijão, mandioca).

No Centro Oeste, as frentes da agricultura comercial e parcela das frentes pecuárias dependeram do crescimento dos mercados do núcleo dinâmico da economia Centro-Sul, da construção de infraestrutura de transporte ligando- os com partes do Centro-Oeste e da disponibilidade de terras de elevado potencial agropecuário (MUELLER, 1983). O governo federal elaborou grandes projetos de rodovias que facilitavam o estimulo à imigração e à formação de atividades econômicas, como a Belém- Brasília, a Cuiabá- Santarém, a Cuiabá- Porto Velho- Manaus, a Perimetral 
Norte e a Transamazônica, todos inseridos no Programa de Integração Nacional - PIN, que ocorreu no início dos anos 70 (PRATES e BACHA, 2011).

Em 1972, foi criada a Empresa Brasileira de Pesquisa Agropecuária EMBRAPA, que teve grande mérito em constituir um numeroso grupo de pesquisadores qualificados e altamente especializados que passaram a adaptar e gerar tecnologias para as diversas explorações agrícolas brasileiras, colaborando após a segunda metade da década de 1970, para os notáveis ganhos de produtividade obtidos, para a viabilização da expansão em direção ao Centro-Oeste e ao Norte do país, adaptando tecnologias, variedades, raças e etc. (NETTO et al., 2002)

Também foi criado o Programa Nacional do Álcool (PROÁLCOOL), em reação a crise do petróleo durante os anos 70, a fim de reduzir a dependência do país em combustível importado, tendo como matriz básica o aproveitamento da capacidade ociosa das destilarias anexas às usinas de açúcar, no sentido de contribuir para a produção de álcool anidro a ser adicionado à gasolina (GAUDER et al., 2011; SHIKIDA; BACHA, 1999).O programa dava continuidade ao processo de expansão da agroindústria açucareira-alcooleira nacional, aumentando a produção de safras agroenergéticas e a capacidade industrial de transformação, incrementando seu uso também no setor químico (BRAY et al., 2000).

O objetivo governamental de ocupar a região amazônica e integrá-la na economia brasileira começou na década de 60 e intensificou na década de 70, envolvendo necessariamente o assunto de direitos à propriedade. Em razão disso, foi criado em 1971, o INCRA (Instituto de Colonização e Reforma Agrária), agência federal que seria encarregada de todos os assuntos relacionados à posse de terra no Brasil e responsável por implementar políticas na Amazônia (MUELLER et al., 1994). Dois programas também se destacaram no período, o Programa para o Desenvolvimento do Cerrado (POLOCENTRO) e o Programa de Cooperação Nipo-Brasileira para o Desenvolvimento do Cerrado (PRODECER). O principal instrumento desses programas foi o crédito supervisionado, com linhas de crédito abrangentes incluindo a indústria de insumos e de transformação, sendo previstos créditos para investimentos, despesas operacionais e assistência técnica (VIEIRA JUNIOR et al., 2014).

Os programas incentivaram a colonização agrária por sulistas, com mais de um milhão de famílias migrando dos estados do Rio Grande do Sul, Santa Catarina e 
Paraná, a partir de 1975. Estas migraram e alteraram a economia tradicional de pecuária e de baixa produtividade e a estrutura agrária, agora voltada à exportação e com um elevado emprego de capital, principalmente pela produção de arroz e soja. Essa mudança foi indispensável justamente no momento em que, em função da crise mundial da dívida externa (deflagrada em 1982), a agricultura de soja voltada à exportação revelou-se um importante gerador de divisas e o Centro-Oeste foi visto como principal espaço econômico do desenvolvimento agrário brasileiro. Os promotores da primeira agroindustrialização foram agroindústrias nacionais do Sul do Brasil, especificamente empresas particulares e cooperativas (KOHLHEPP e BLUMENSCHEIN, 2000).

O segundo choque de petróleo, em 1979, e a desestabilização financeira que se seguiu começaram a restringir a capacidade da economia de controlar a inflação (CARVALHO, 1991). A aceleração da inflação e a não correção, em valores correspondentes, das taxas de juros do crédito rural, fizeram que o subsídio crescesse no final da década de 70. Mesmo aumentando o valor da exigibilidade dos bancos, os volumes aportados pelo Tesouro Nacional necessitavam ser cada vez maiores, pressionando as finanças públicas e colocando em risco a política do crédito rural (BACCARIN, 2008).

\subsection{O DESEMPENHO DA AGROPECUÁRIA NOS ANOS 80 E 90}

A partir dos anos 80, o modelo de crescimento enfrentou circunstâncias adversas como a drástica redução do crédito e a eliminação de subsídios, recessão externa e queda das cotações de inúmeras commodities, baixo crescimento da demanda externa e forte desestabilização da economia após o Plano Cruzado, com sistemática elevação da taxa de inflação (MELO, 1990). Para Gasques e Villa Verde (1990), apesar da crise econômica dos anos 80, o crescimento agrícola se deu de forma relativamente favorável numa época em que a economia como um todo cresceu pouco. O crescimento diferenciado foi possível devido as características particulares da agricultura no que se diz respeito à organização da produção, características do mercado, natureza do mercado de trabalho e políticas agrícolas de apoio ao setor, além das quedas nos custos de produção e aumentos de produtividade.

A PGPM (Política de Garantia de Preços Mínimos) criada em 1945, cumpriu nos anos 80 importante papel na formação de expectativas pelos agricultores e na tentativa 
de direcionamento da produção para esta ou aquela cultura, julgada prioritária pelas autoridades governamentais, reduzindo os riscos associados à crescente instabilidade monetária da economia brasileira. Os principais atendidos pela PGPM foram algodão, soja, arroz e milho (BACCARIN, 2008).

$\mathrm{Na}$ década de 90 ocorreram modificações do crédito rural e na política de comercialização, mas também importantes mudanças macroeconômicas, como a abertura da economia e os planos de estabilização econômica. Os fatores decisivos que forçaram transformações acentuadas nos gastos públicos foram: o corte nos subsídios agrícola, a criação de novas fontes de crédito rural e a mudança na forma de atuação do governo e a criação de novos instrumentos de comercialização (GASQUES e BASTOS, 2014).

A agricultura e a indústria processadora de alimentos viram-se diante de condições mais desfavoráveis no contexto de estabilização de preços e ajuste macroeconômico. (CAMPOS e PAULA, 2002). Entretanto, segundo Haguenauer et al., (2001), o complexo agroindustrial manteve seu peso no PIB (com crescimento de 1\% entre 1990 e 1996) e foi o único no qual a maioria das atividades industriais aumentou sua participação. Para o autor, as cadeias não perderam peso durante a recessão por participarem de um setor bastante competitivo e pela demanda por alimentos ser relativamente inelástica à queda de renda.

\subsection{O COMPORTAMENTO RECENTE DA AGROPECUÁRIA BRASILEIRA E AS PRINCIPAIS POLÍTICAS PÚBLICAS PARA O SETOR}

Segundo Barros (2014), no final da década de 1990, o mercado internacional entrou num rápido processo de crescimento, com a forte retomada da economia chinesa, cujos reflexos foram importantes para uma série de países emergentes, principalmente para o Brasil. A partir de 2003, os preços das commodities em geral sofreram grande aumento causados em grande parte pelas importações da China.

Dessa forma, a partir dos anos 2000, um dos primeiros pontos que afetaram positivamente a agricultura, foram os resultados de desempenho indicados pelo valor da produção agropecuária. Somando-se os valores reais, houve um acréscimo de mais de 100\% entre 2000-2012. Volumes elevados de produção e preços favoráveis estiveram 
como causas dessa evolução nos preços dos produtos agrícolas e das carnes (bovina, suína e frango) (GASQUES e BASTOS, 2014).

Com base na discussão mundial sobre a substituição das energias fósseis por energias renováveis e em razão da queda do preço do açúcar no mercado mundial, foi apresentado, também nos anos 2000, o primeiro veículo produzido em série no Brasil com motor flex-fuel, movido à gasolina, a etanol ou com uma mistura dos dois. Em 2010, 92\% dos veículos novos vendidos já eram equipados com esse tipo de motor. (KOHLHEPP, 2010).

Algumas das linhas de crédito de investimento mais importantes dos anos 2000 em seguinte foram: o Programa de Modernização da Agricultura e Conservação de Recursos Naturais (MODERAGRO), que fomenta setores da produção, beneficiamento, industrialização e armazenamento de produtos agropecuários, apoiando a recuperação de solos por meio do financiamento para aquisição, transporte, aplicação e incorporação de corretivos agrícolas e promovendo ações relacionadas à defesa animal, o Programa de Sustentação do Investimento para Aquisição de Bens de Capital (PSI-BK), uma linha de crédito com a finalidade de financiar máquinas e equipamentos agrícolas novos aos produtores rurais, o PRONAF (Programa Nacional de Fortalecimento da Agricultura Familiar)- Investimento- Banco Nacional de Desenvolvimento Econômico e Social (BNDES), constituído de três tipos de intervenção: melhoramento das infra-estruturas rurais, apoio ao crédito para a agricultura familiar e formação de agricultores (ABRAMOVAY e PIKETTY, 2005; BUAINAIN et al., 2014; MAPA, 2014). 


\section{CAPÍTULO 3}

\section{ÁREA DE ESTUDO}

O território brasileiro possui aproximadamente $8.515 .767 \mathrm{~km}^{2}$ (IBGE, 2004) e pode ser orientado por 6 biomas: Amazônico, Cerrado, Floresta da Mata Atlântica, Caatinga, Pantanal e os Pampas.

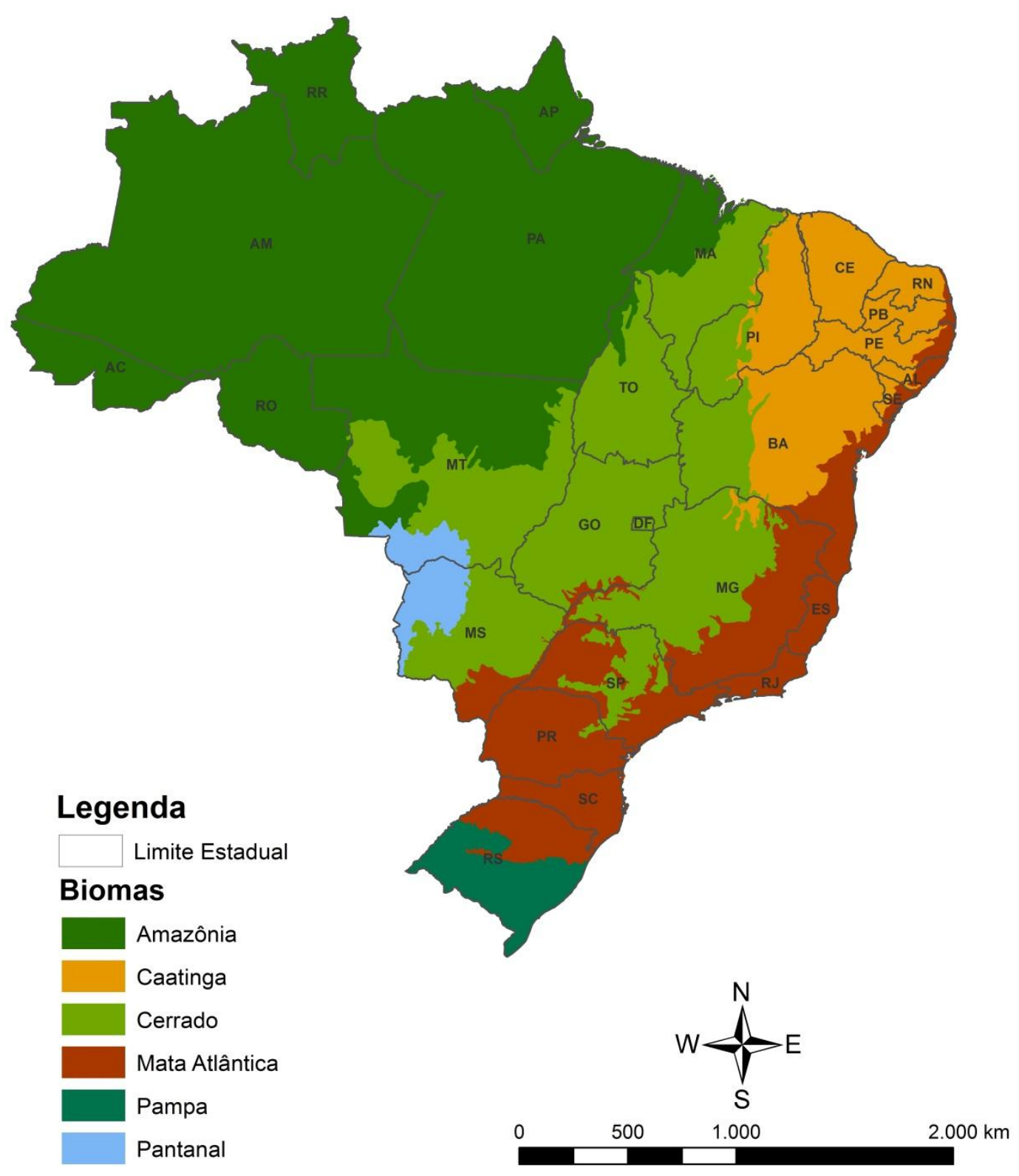

Figura 1. Biomas brasileiros (Fonte: IBGE) 
O bioma da Amazônia cobre cerca de 48,29\% do território nacional, compreendendo a região Norte do país e porção norte do estado do Mato Grosso e oeste do Maranhão. Pode ser classificado como uma floresta tropical com clima quente e úmido, chuvas fortes e solos altamente ácidos de baixa fertilidade e drenagem (IBGE, 2004; RADA, 2013).

A região do Cerrado compreende cerca de 23,92\% da área total do país, abarcando a região Centro-Oeste e também porções da região Norte, oeste do Nordeste e parte do Sudeste e Sul do país. O clima dominante no Bioma Cerrado é o tropical quente subúmido, com apenas duas estações, uma seca e outra chuvosa. A precipitação varia entre 600 e $2200 \mathrm{~mm}$ anuais, com as áreas limítrofes com o Bioma Caatinga e Amazônia recebendo, respectivamente os mais baixos e os mais altos volumes anuais de chuva. As temperaturas médias anuais variam entre $27^{\circ}$ e $22^{\circ} \mathrm{C}$ (IBGE, 2004). Os solos são predominantemente antigos, bem drenados, com baixa fertilidade natural e acidez acentuada. Entretanto, o relevo da região que varia entre plano e suave ondulado o favorece a agricultura mecanizada e a irrigação (BALBINO et al., 2011).

O bioma Pantanal compreende cerca de $1,76 \%$ da área total do território brasileiro e está localizado nos Estados de Mato Grosso e Mato Grosso do Sul (IBGE, 2004). O ecótono entre zonas aquáticas e terrestres mudam de localização estacionalmente durante o ciclo de inundação. Tal variabilidade, combinada com a topografia local, confere uma complexidade ecológica encontrada nos padrões aquáticos, semi-aquáticos e de vegetação terrestre (HAMILTON, 2002). As áreas inundadas do Pantanal nas terras baixas são afetadas pelas pastagens, atividades agrícolas e mudanças no uso do solo nas terras altas causando efeitos deletérios na ecohidrologia do Pantanal (BULLER et al., 2015).

A Mata Atlântica cobre a região Sudeste e Sul do país, estendendo-se até o litoral da região nordestina. Compreende um complexo ambiental que incorpora cadeias de montanhas, platôs, vales e planícies de toda a faixa continental leste brasileira. Sua área de abrangência tem hoje a maior densidade população e lidera as atividades econômicas do país (IBGE, 2004). Caracteriza-se pela ocorrência de dupla estacionalidade climática: uma tropical, com intensas chuvas de verão, seguidas de estiagens acentuadas, e outra subtropical, sem período seco característico, mas com seca 
fisiológica, que é provocada pelo frio do inverno, com temperatura média inferior a $15^{\circ} \mathrm{C}$ (BALBINO et al., 2011).

Na região Sul do Brasil, o bioma pampa é caracterizado por pastagens naturais, arbustos e árvores esparsas. O clima é subtropical úmido com estações bem definidas, o que permite o crescimento de espécies tropicais e temperadas na mesma área, resultando em um elevado potencial para a produção de forragem ao longo do ano (DICK et al., 2015). Uma redução de $25 \%$ da área total de campos naturais ocorreu nos últimos 30 anos, devido à forte expansão das atividades agrícolas (OVERBECK et al., 2007).

O bioma da Caatinga apresenta-se em toda região do Nordeste e parcelas do estado de Minas Gerais. A caatinga caracteriza como um dos domínios de natureza de singularidade marcante no contexto climático e hidrológico de um continente dotado de continuas extensões de terras úmidas. Os atributos do bioma estão centrados no tipo de clima semi-árido, muito quente e sazonalmente seco, com temperaturas médias entre $25^{\circ}$ e $29^{\circ} \mathrm{C}$ e precipitação média anual entre $268 \mathrm{~mm}$ e $800 \mathrm{~mm}$ (AB'SÁBER, 2013). As regiões semi-áridas freqüentemente sofrem com anos de chuvas abaixo da média e secas bruscas, ameaçando o desenvolvimento econômico, os meios sustentáveis de subsistência humana e a qualidade ambiental (MONTENEGRO et al., 2012).

As regiões Sudeste, Sul e Nordeste apresentam maior participação percentual no Produto Interno Bruto, com 55,4\%, 16,5\% e 13,5\% respectivamente (IBGE, 2012a). Os estados da região Sudeste e Sul apresentam também a maior participação no PIB agropecuário, indústria e serviços (IBGE, 2012b). Contudo, segundo a pesquisa de Contas Regionais do Brasil do IBGE (2012), entre 2002 e 2010, o PIB das regiões Sudeste e Sul reduziu de $56,7 \%$ para $55,4 \%$ e $16,9 \%$ para $16,5 \%$ respectivamente e o PIB das regiões Norte, Centro Oeste e Nordeste aumentou de 4,7\% para 5,3\%, 8,8\% para $9,3 \%$ e $13 \%$ para $13,5 \%$ respectivamente. O avanço da fronteira agrícola, os incentivos regionais, a maior mobilidade das plantas industriais, além do avanço das novas classes consumidoras são alguns dos fatores que influenciaram esse resultado.

O Norte e em especial o Centro-Oeste ampliaram sua participação no PIB agropecuário. A região Norte apresentava 4,1 \% do PIB agropecuário total em 1970 e em 2007 subiu para 8,9\%, a região Centro- Oeste em 1970 participava 7,4\% do PIB agropecuário total e em 2007 sua participação acresceu para 16,5\% (IBGE, 2009). O pessoal ocupado na agricultura caiu de 21,1 milhões para 16, 4 milhões entre as datas de 
referência: 31 de dezembro de 1980 e 31 de dezembro de 2006. Entre as regiões, o Nordeste absorve o maior contingente, quase 8 milhões de pessoas, boa parte em atividades de baixa produtividade e o Centro-Oeste absorve o menor número de pessoas, pouco mais de 1 milhão, em que pese o elevado dinamismo da agropecuária nessa região (BUAINAIN e DEDECCA, 2010).

Apesar do melhor desempenho no PIB, o analfabetismo, a precariedade de apoio médico e educacional, a carência de infraestrutura, de assistência técnica e de informações tecnológicas, a fragilidade de mercados, a estrutura agrária altamente concentrada constituem fatos comuns na região Nordeste e na região amazônica. (HOMMA et al., 2014; SILVA et al., 2014). Cerca de 61,3\% ou 1099 municípios nas regiões Norte e Nordeste do Brasil estão no grupo de Baixo Desenvolvimento Humano (PNUD,2012). O Nordeste e Norte exibem a maior taxa de analfabetismo do país, em torno de $15,9 \%$ e $9,1 \%$ para cada região. Em 2012, o rendimento médio mensal de pessoas ocupadas no Norte e Nordeste foi de R\$ 1058 e R\$ 907 concomitantemente, valor menor do que quando comparado ao das regiões Sudeste, Sul e Centro Oeste que possuem rendimento médio de $\mathrm{R} \$ 1656$, $\mathrm{R} \$ 1528$ e $\mathrm{R} \$ 1744$ respectivamente (IBGE,2013). 


\section{CAPÍTULO 4}

\section{MATERIAL E MÉTODOS}

\subsection{Séries temporais da produção agrícola e bovina}

No presente trabalho foram considerados dados municipais do efetivo do rebanho bovino entre o período de 1978 e 2012 e da quantidade produzida em toneladas das produções de cana de açúcar, milho e soja no período de 1993 a 2012. Os períodos utilizados são relativos à disponibilidade de dados adquiridos do IBGE (IBGE, 2012). As informações municipais de produção agrícola são provenientes da Pesquisa Agrícola Municipal elaborada pelo IBGE que fornece informações estatísticas sobre quantidade produzida, área plantada e colhida, rendimento médio e valor da produção dos produtos das culturas temporárias e permanentes. Os dados da produção bovina são oriundos da Pesquisa Pecuária Municipal também elaborada pelo IBGE e que dispõe informações estatísticas sobre efetivo dos rebanhos, a quantidade e o valor dos produtos de origem animal, bem como os números de vacas ordenhadas e ovinos tosquiados. Tais pesquisas são anuais e atingem todo o território brasileiro. Os dados de produções foram organizados em uma tabela e acoplados ao mapa municipal do Brasil no programa ArcGis 10 (formato shapefile), permitindo sua espacialização.

\subsection{Espacialização de produções agrícolas e bovinas e de suas taxas de crescimento e aceleração}

Mapas foram confeccionados com dados absolutos de produção bovina no período de 1978 a 2012 e de produções de cana de açúcar, milho e soja no período de 1993 a 2012. Para facilitar a visualização dos dados temporais foi calculado o somatório de produção bovina em 6 períodos iguais de 10 anos (1978-1987; 1983-1992; 19881997; 1993-2002; 1998-2007; 2003-2012). O somatório de produção de cana de açúcar, milho e soja foi realizada para 3 períodos iguais de 10 anos (1993-2002; 1997-2008; 2003-2012).

As análises das taxas de crescimento (variação percentual) e aceleração das produções consideraram valores absolutos e normalizados pela área do município a fim de reduzir dados inconsistentes. Valor normalizado entende-se como a produtividade parcial da terra ou taxa de lotação no caso da pecuária. Mapas da taxa de crescimento 
relativo (\%) das produções agropecuárias por município foram elaborados no ARCGIS 10 .

O período analisado de produção bovina foi dividido em 7 períodos iguais contendo o somatório de dados em intervalos de 5 anos (1978-1982; 1983-1987; 19881992; 1993-1997; 1998-2002; 2003-2007; 2008-2012). Para a produção de cana de açúcar, milho e soja cujo período é de 1993 a 2012, a produção foi dividida em 4 períodos iguais contendo o somatório de intervalo de 5 anos (1993-1997; 1998-2002; 2003-2007; 2008-2012). A taxa de crescimento foi calculada a partir da equação (1):

\section{$\frac{\text { (Produçẫo do periodo posterior-Produçâo do período anterior) }}{\text { Produçâo do período anterior }} \times 100$}

A taxa de crescimento de produção bovina resultou em seis mapas, já a taxa de crescimento das produções agrícolas resultou em três mapas. A taxa de aceleração de cada produção foi elaborada a partir da subtração da taxa de crescimento absoluto posterior pela anterior, que foram também representados em mapas. As Figuras 2 e 3 demonstram os procedimentos adotados no cálculo da taxa de crescimento e aceleração ao longo da série temporal.

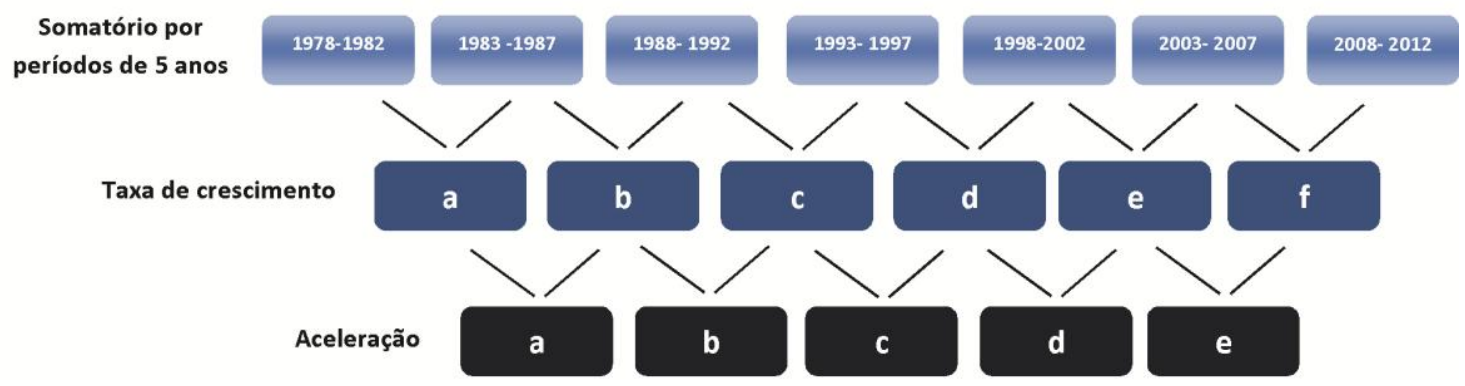

Figura 2. Procedimento para a elaboração dos mapas da taxa de crescimento (variação percentual) e aceleração de produção bovina.

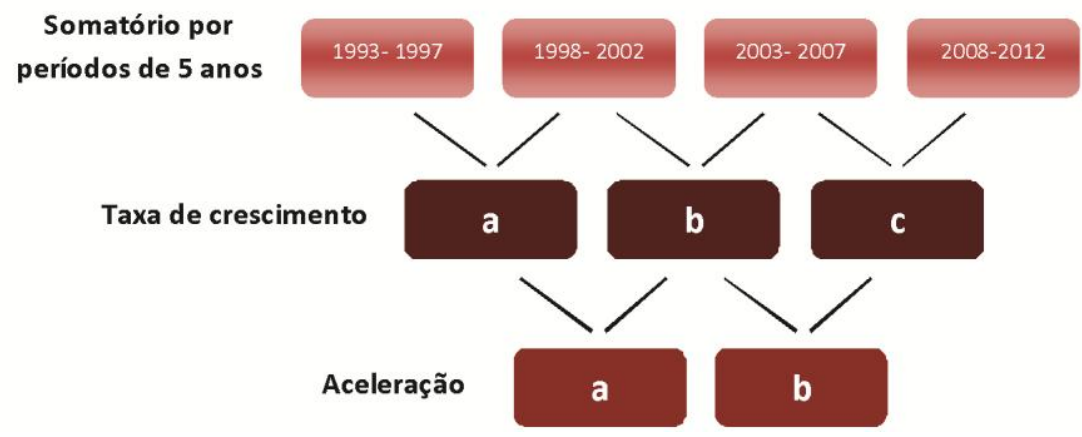


Figura 3. Metodologia da elaboração dos mapas da taxa de crescimento e aceleração do crescimento de produção de cana de açúcar, milho e soja.

\subsection{Análise temporal do ponto médio espacial de produção agrícola e bovina}

A análise temporal do ponto médio espacial das produções no país possibilita avaliar a direção e o deslocamento de cada produção no território brasileiro ao longo do tempo. A latitude e longitude do ponto médio foram calculadas para cada ano conforme as equações:

$$
\begin{aligned}
& \text { Latitude média }=\frac{\sum(\text { latitude } * \text { produção })}{\sum \text { produção }} \\
& \text { Longitude média }=\frac{\sum(\text { longitude } * \text { produção })}{\sum \text { produçã̃o }}
\end{aligned}
$$

Para a produção bovina foram utilizados os anos de 1978 a 2012 e para as produções de cana de açúcar, milho e soja os anos de 1990 a 2012.

\subsection{Análise de correlação de séries temporais de produções agrícolas e bovinas}

A análise de correlação em intervalos temporais entre as produções bovinas e agrícolas permite avaliar uma associação (correlação positiva) ou uma substituição (correlação negativa) do uso da terra. O coeficiente de correlação de Pearson das séries temporais foi calculado entre a produção de cana de açúcar e bovina e entre a produção de soja e bovina, utilizando janelas móveis de 5 anos que transcorrem sobre a série temporal (de 1993 a 1997, de 1994 a 1998, de 1995 a 1999, de 1996 a 2000,...de 2008 a 2012), gerando 16 imagens. O coeficiente de correlação de Pearson é representado pela seguinte equação:

$$
r=\frac{\sum_{i=1}^{n}\left(x_{i}-\bar{x}\right)\left(y_{i}-\bar{y}\right)}{\sqrt{\sum_{i=1}^{n}\left(x_{i}-\bar{x}\right)^{2}} \cdot \sqrt{\sum_{i=1}^{n}\left(y_{i}-\bar{y}\right)^{2}}}
$$

onde $\mathrm{x} 1, \mathrm{x} 2, \ldots, \mathrm{xn}$ e y1, y2 ,.., yn são os valores medidos de ambas as variáveis. 


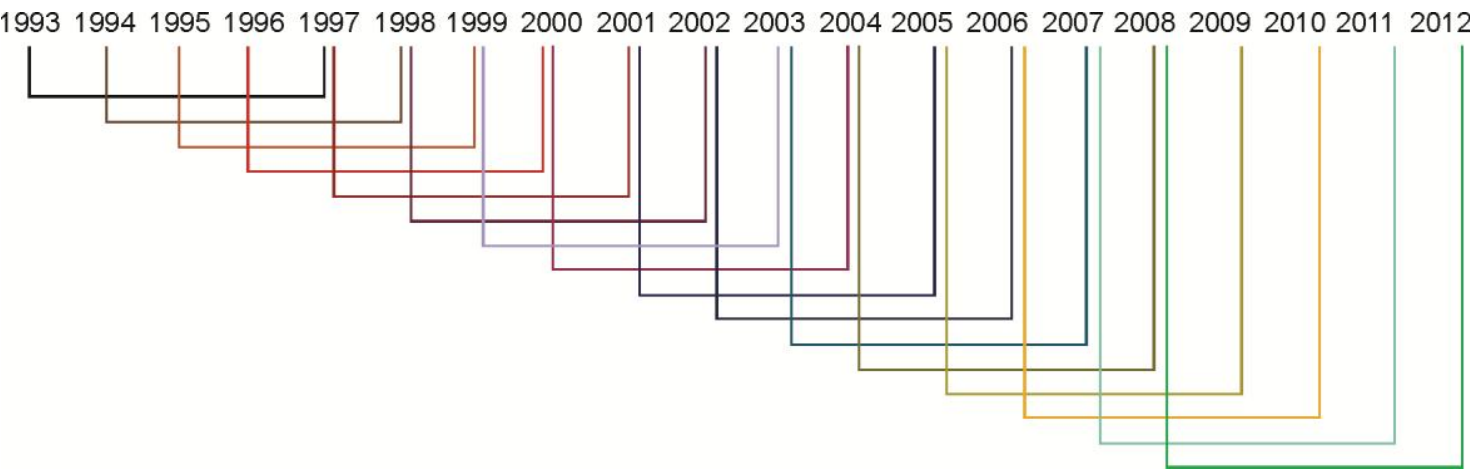

Figura 4. Janela móvel de 5 anos da produção bovina, de cana de açúcar e soja, que transcorre a sobre a série temporal (de 1993 a 1997, de 1994 a 1998, de 1995 a 1999, de 1996 a 2000,...de 2008 a 2012) para a análise de correlação.

Com intuito de considerar apenas as áreas com produções bovinas significativas foi feita uma função condicional para identificar as produções acima de 100.000 cabeças de gado para ser considerada na análise. Para determinar as áreas onde ocorreu a conversão de pasto para lavoura (correlação inversa) nos 16 períodos analisados, foi utilizada a função condicional para selecionar os valores menores que $-0,3$. Tal processo resultou em16 mapas.

Com o objetivo de especificar qual produção diminuiu e qual aumentou utilizouse como máscara os resultados da média da aceleração do crescimento entre o período de 1993 a 2012 de produção bovina, de cana de açúcar e de soja. Dessa forma foi elaborada uma função condicional para obter como resultado somente as correlações inversas, onde:

- Os valores da média da aceleração bovina fossem menores que 0 e os valores da média da aceleração da cana de açúcar fossem maiores que 0 , para apresentar municípios onde a produção bovina diminuiu e a produção de cana de açúcar aumentou;

- Os valores da média da aceleração de produção bovina fossem maiores que 0 e os valores da aceleração de produção de cana de açúcar fossem menores que 0 , para apresentar municípios onde a produção bovina aumentou e a produção de cana de açúcar diminuiu;

- Os valores da aceleração de produção bovina fossem menores que 0 e os valores de produção de soja fosse superior a 0 , para apresentar 
municípios onde a produção bovina diminuiu e a produção de soja aumentou;

- Os valores da aceleração de produção bovina fossem maiores que 0 e os valores da aceleração de produção de soja fossem menores que 0 , para apresentar municípios onde a produção bovina aumentou e a produção de soja diminuiu.

A partir dos resultados foram analisados apenas os 6 últimos períodos: 20032007, 2004-2008, 2005- 2009, 2006-2010, 2007-2011, 2008-2012. 


\section{CAPÍTULO 5}

\section{RESULTADOS}

\subsection{Produções}

\subsubsection{Produção Bovina (1978-2012)}

Durante o período 1978-1997 somente o município de Corumbá (MS) possuía produção superior a 9,5 milhões de cabeças de gado (Figura 5). Nesse mesmo período, os municípios com produções entre 5 e 9,5 milhões de cabeças de gado estavam presentes nos seguintes Estados: GO, MG, MS e RS.

No período 1993-2002 destacaram-se os municípios de Corumbá e Ribas do Rio Pardo (MS) com produção bovina superior a 9,5 milhões cabeças de gado. Os municípios com a produção entre 5 e 9,5 milhões de cabeças de gado estão presentes no GO, MS e RS.

Os períodos 1998-2007 e 2003-2012 apontaram produções superiores a 9,5 milhões de cabeças de gado nos municípios de Corumbá (MS), Ribas do Rio Pardo (MS) e São Felix do Xingú (PA). O último período 2003-2012 apresentou produções entre 5 e 9,5 milhões de cabeças de gado nos municípios dos seguintes Estados: GO, MS, MT, PA, RO e RS. 

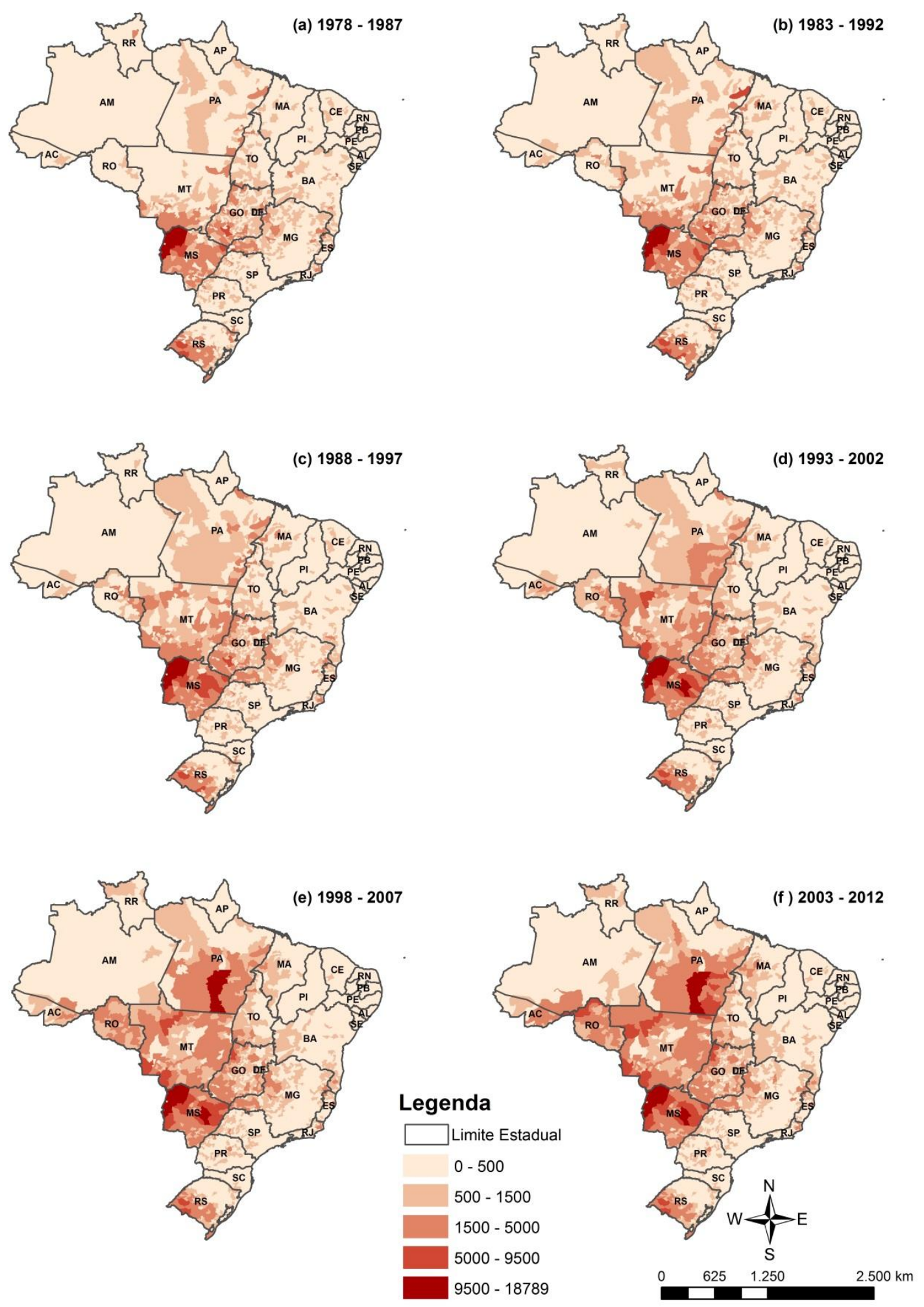

Figura 5. Produção bovina (em mil cabeças). (a) 1978-1987; (b)1983-1992; (c) 19881997; (d) 1992-2002; (e) 1998-2007; (f) 2003-2012. 


\subsubsection{Produção de Cana de Açúcar (1993-2012)}

Os municípios que apresentaram produção de cana de açúcar superior a 15 milhões de toneladas durante 1993-2002 estavam nos seguintes Estados: SP, RJ, AL e MT (Figura 6). As produções entre 8,5 e 15 milhões de toneladas estiveram presentes em municípios de SP, MT, MS, PR, MG, GO, BA, PE e PB. Durante esse período, dos 98 municípios com produção superior a 8,5 milhões toneladas de cana de açúcar, 74 estavam em SP.

No período 1997-2008 as produções acima de 15 milhões de toneladas estiveram presentes nos municípios de SP, RJ, AL, MT, PR e GO. Os municípios com produção entre 8,5 e 15 milhões estavam localizados em SP, PR, MT, MS, GO, MG, AL, PB e PE.

No último período 2003-2012 os municípios que exibiram produção superior a 15 milhões de toneladas eram dos seguintes Estados: SP, RJ, MG, MT, MS, GO, PR e PB. As produções entre 8,5 e 15 milhões de toneladas de cana de açúcar estiveram presentes nos municípios de SP, RJ, PR, MG, MT, MS, GO, BA, AL e PE. . Dos 203 municípios com produção superior a 8,5 milhões de toneladas, 136 pertenciam a SP. 

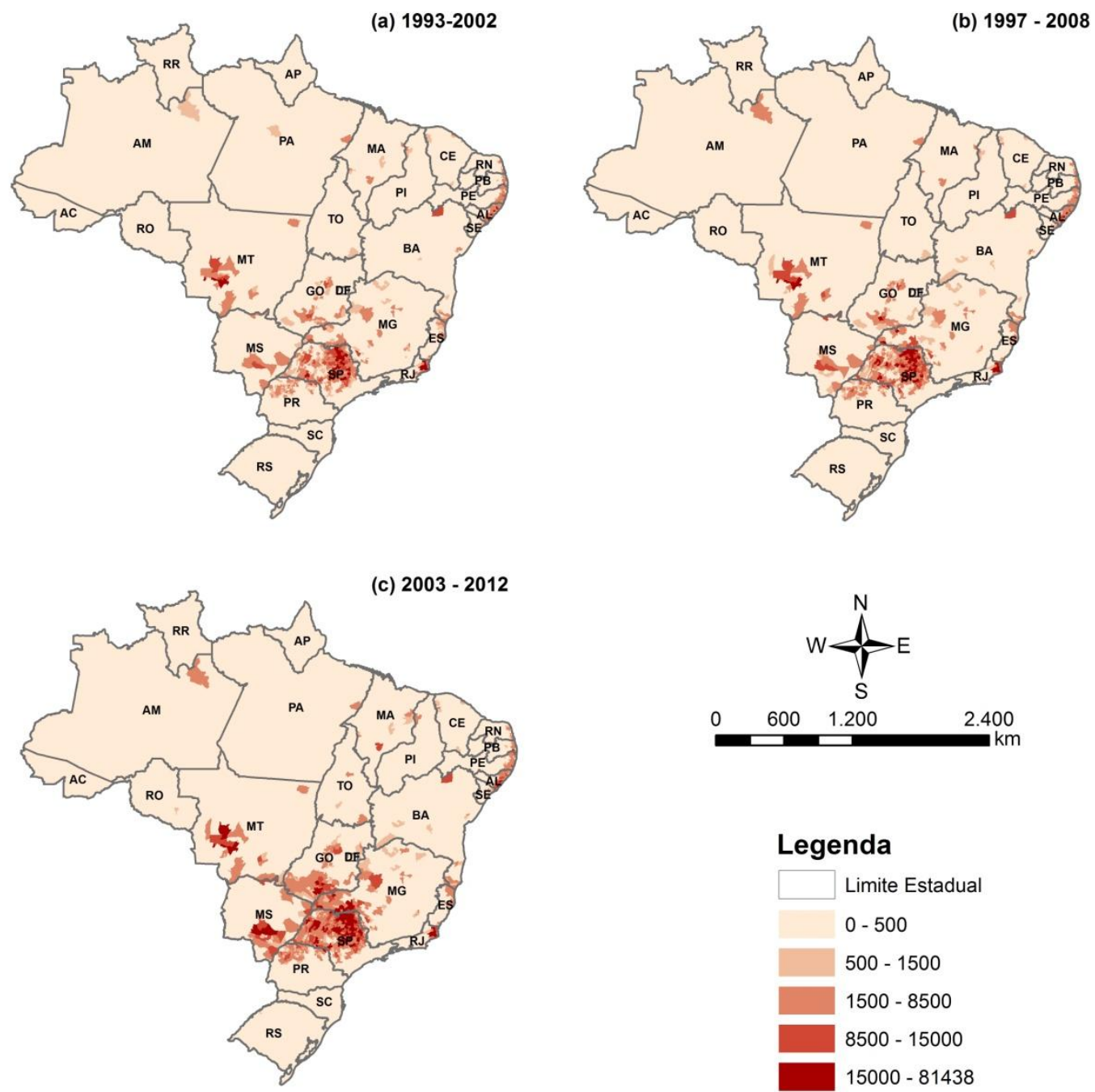

Figura 6. Produção de cana de açúcar (em mil toneladas). (a) 1993-2002; (b) 19972008; (c) 2003-2012. 


\subsubsection{Produção de Soja (1993- 2012)}

No período 1993-2002 os municípios de Sorriso (MT) e Campo Novo dos Parecis (MT) exibiram produção superior a 7,5 milhões de toneladas de soja (Figura 7). Os municípios com produção entre 1,5 -7,5 milhões de toneladas estiveram presentes em MT, MS, GO, BA, PR e RS.

No período 1997-2008 os municípios com produção superior a 7,5 milhões de toneladas de soja permanecem em MT. Observou-se um maior número de municípios com produção entre 1,5-7,5 milhões de toneladas em MT, MS, GO, MG, BA, MA, PR e RS.

O período 2003-2012 destacou os municípios de MT: Sorriso, Sapezal, Nova Mutum, Campo Novo dos Parecis e Diamantino com produções superiores a 7,5 milhões de toneladas de soja. Os municípios com produção entre 1,5 - 7,5 milhões de toneladas estiveram presentes em GO, MS, BA, MA, PI, RS, PR e DF. 

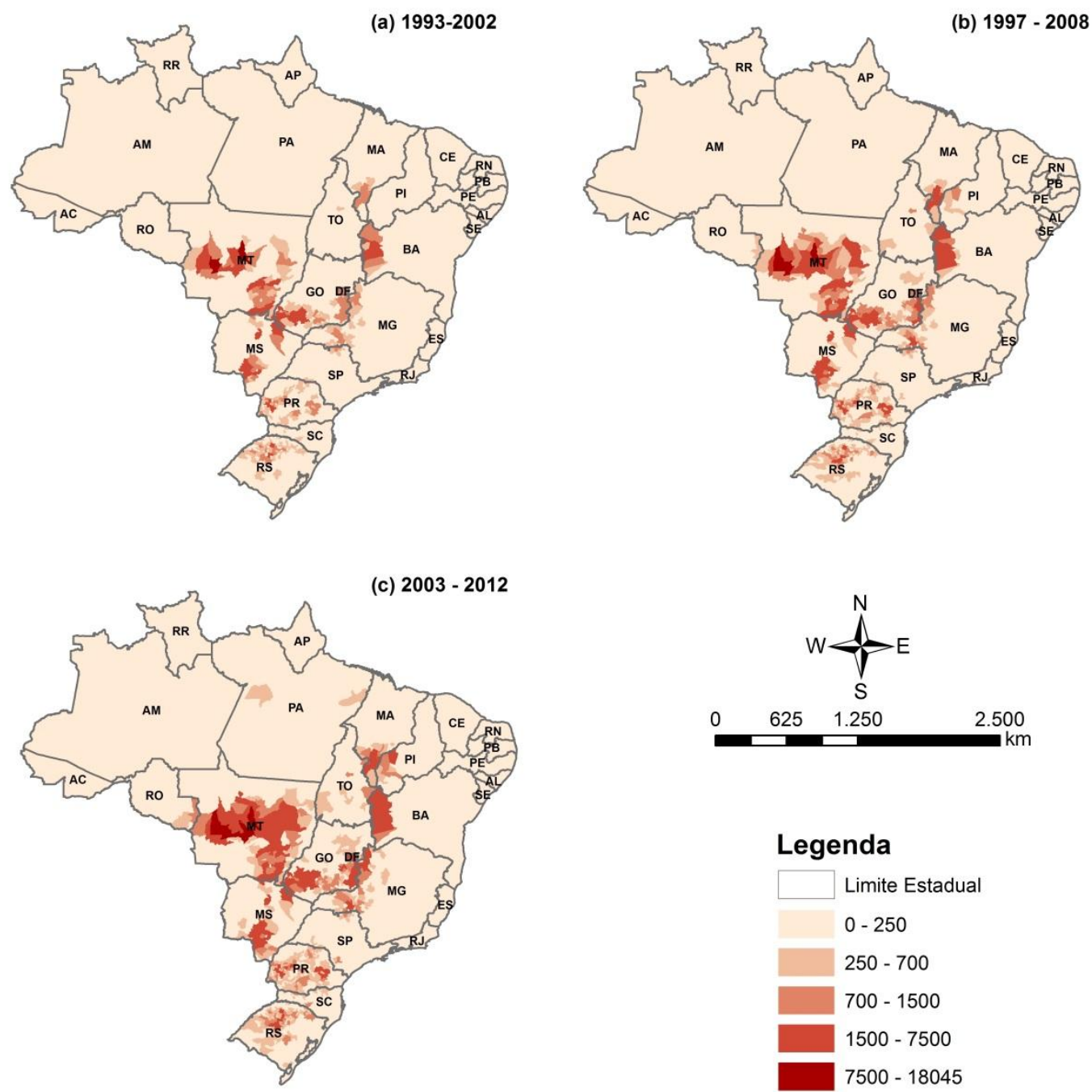

Legenda

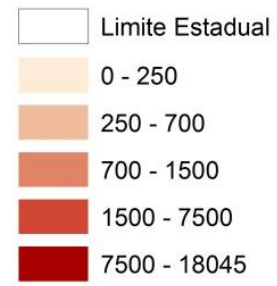

Figura 7. Produção de cana de açúcar (em mil toneladas). (a) 1993- 2002; (b) 19972008; (c) 2003-2012. 


\subsubsection{Produção de Milho (1993 - 2012)}

Durante o período 1993-2002, os municípios de Jataí (GO) e Rio Verde (GO) apresentaram as maiores produções de milho no Brasil, superior a 2,5 milhões de toneladas de milho (Figura 8). Produções entre 850 mil e 2,5 milhões de toneladas estiveram presentes nos municípios de GO, MS, MT, MG, PR, SC, BA e DF.

O período 1997-2008 destacou os municípios de Jataí (GO), Chapadão do Céu (GO), Lucas do Rio Verde (MT) e Sorriso (MT) com produções superiores a 2,5 milhões de toneladas de milho. As produções entre 850 mil e 2,5 milhões de toneladas estavam presentes nos municípios de MT, MS, GO, MG, PR, SP, SC, BA e DF.

Os municípios com produções superiores a 2,5 milhões de toneladas de milho no último período 2003-2012 estavam em MT, GO, MS, MG, BA e DF. . Os municípios de MT, MS, GO, PR, SC, RS, SP, MG e BA apresentaram produções entre 850 mil toneladas e 2,5 milhões de toneladas de milho. Os municípios do Piauí e Pará apresentaram no mesmo período produções entre 450 mil e 850 mil toneladas de milho. 

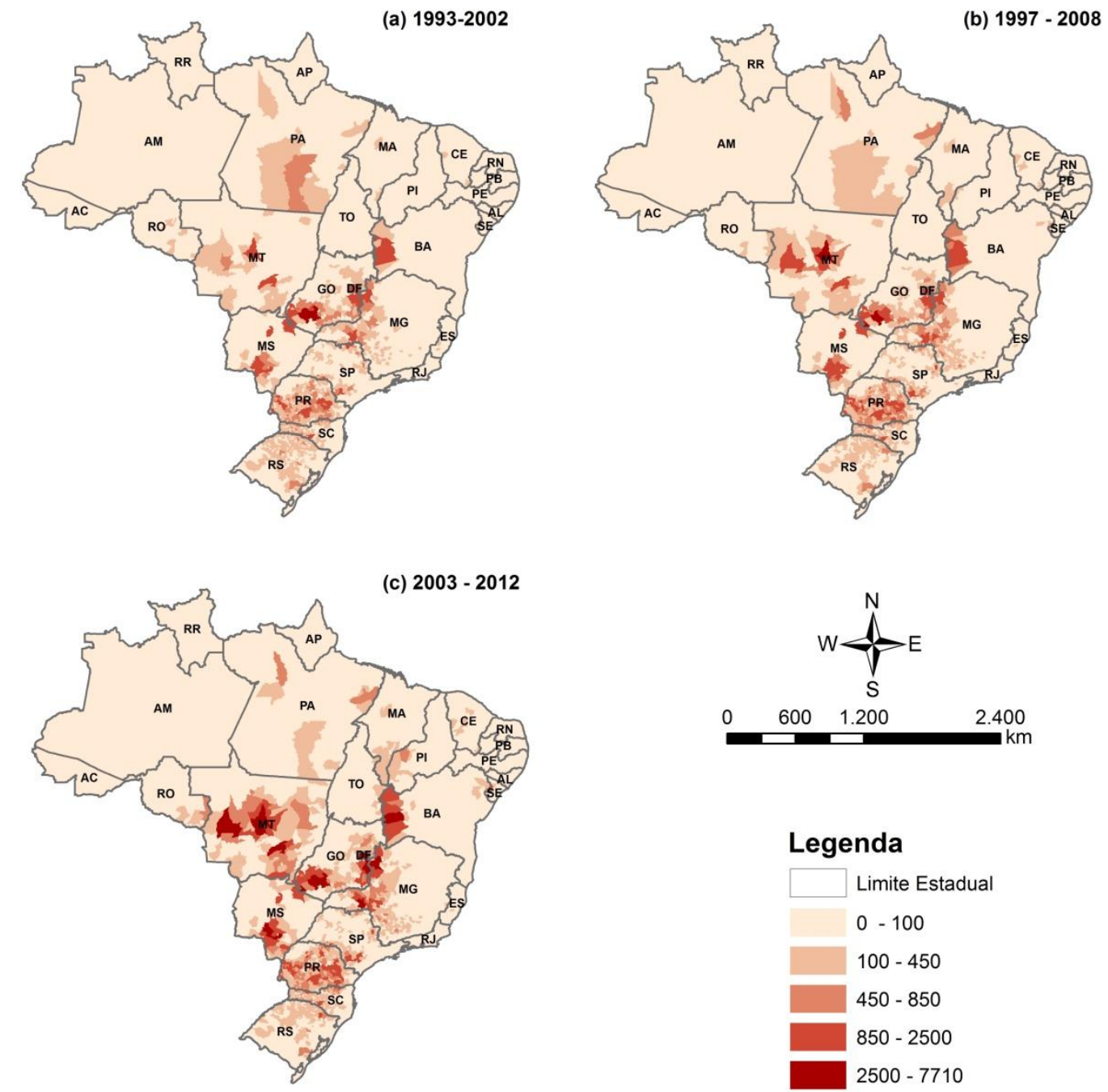

\section{Legenda}

\begin{tabular}{|l|}
\hline \\
\hline \\
$0-100$ \\
$100-450$ \\
$450-850$ \\
$850-2500$ \\
$2500-7710$ \\
\hline
\end{tabular}

Figura 8. Produção de milho (em mil toneladas) para os seguintes períodos: (a) 19932002; (b) 1997-2008; (c) 2003-2012. 


\subsection{Taxa de Crescimento das Produções}

\subsubsection{Taxa de Crescimento de Produção Bovina (1978 - 2012)}

\section{Resultado com dados absolutos}

A taxa de crescimento usando os dados absolutos de produção bovina (Figura 9) apresentou valores superiores a 50\% nos municípios de quase todos estados brasileiros nos períodos 1978-1987, 1983-1992 e 1988-1997.

O período 1988-1997 indicou redução da taxa de crescimento superior a 50\% em municípios ao norte de MG, na BA, CE, RN, PB, PE, AL e SE. O período 1988-1997 revelou o maior número de municípios, cerca de 174, com redução do crescimento superior a $50 \%$ (Tabela 1$)$.

No período 1993-2002 as taxas de crescimento superiores a 50\% estiveram em sua maioria em municípios na porção norte de $\mathrm{MT}$, GO, porção sul da $\mathrm{AM}, \mathrm{RO}, \mathrm{AC}$, PA, RO, MA, TO, PI, PE, AL, BA, no norte de MG, PR, SC, RG, RJ e ES. O período 1998-2007 aponta taxa de crescimento de até 50\% em municípios em quase todos estados do país, contudo a taxa de crescimento de produção superior a $50 \%$ concentrouse em municípios da região Norte e nos municípios na porção norte de MT e MA. .

O período 2003-2012 apresentou o menor número de municípios com taxa de crescimento superior a 50\% (Tabela 1). Municípios de RO, PA, AP, RR, AM e AC na região Norte do país apresentaram taxa de crescimento superior a 50\%. O mesmo foi visto em municípios da região Nordeste e em alguns municípios do MT, SP, RS e SC. Também nesse período observou-se redução da taxa de crescimento de produção em muitos municípios do Brasil, principalmente no estado do MS, sul do MT, SP, PR, sul do GO e parte oeste de MG.

Os resultados da média da taxa de crescimento de produção bovina a partir dos dados absolutos de produção de 1978 a 2012 (Figura 10) mostraram que valores superiores a $50 \%$ concentraram em municípios ao norte do MT, sul do AM, PA, AC, RO, RR, AP , englobando também os municípios do MS, GO, MA, TO, PI, BA, ES e norte de MG . Municípios da região Sul do país apresentaram taxa de crescimento superior a 50\%, entretanto muitos municípios exibiram redução de taxa de crescimento. 
A redução do crescimento de produção bovina também apareceu nos municípios do Estado de São Paulo, Mato Grosso do Sul, Goiás e na porção central do Nordeste.

Tabela 1. Número de municípios brasileiros conforme o crescimento de produção de bovinos a partir de dados absolutos.

\begin{tabular}{|llllll|}
\hline Período & Crescimento & Crescimento & Redução & Redução & Estagnação \\
& Alta $(>50 \%)$ & Baixa $(<50 \%)$ & Alta $(>50 \%)$ & Baixa (<50\%) & \\
\hline $1978-1987$ & 458 & 2060 & 22 & 1634 & 1391 \\
\hline $1983-1992$ & 679 & 2312 & 44 & 1450 & 1081 \\
\hline $1988-1997$ & 1298 & 1834 & 174 & 2192 & 68 \\
\hline $1993-2002$ & 881 & 2128 & 168 & 2372 & 17 \\
\hline $1998-2007$ & 545 & 3251 & 54 & 1692 & 24 \\
\hline $2003-2012$ & 271 & 2994 & 70 & 2199 & 31 \\
\hline Média & 1654 & 2618 & 0 & 1288 & 5 \\
\hline
\end{tabular}

\section{Resultado com dados normalizados}

A comparação das taxas de crescimento a partir de dados absolutos e normalizados apresentaram pequenas diferenças (Tabela 2). O mapa da taxa média de crescimento de produção bovina com dados normalizados (Figura 12) apresentou resultado mais abrandado com menos municípios com taxa de crescimento superior a $50 \%$, contudo, as ocorrências são similares, os municípios da Região Norte e CentroOeste apresentaram taxa de crescimento superior a $50 \%$ e os municípios da região Sul e de SP apresentaram redução da taxa de crescimento.

Tabela 2. Número de municípios brasileiros conforme o crescimento de produção de bovinos a partir de dados normalizados.

\begin{tabular}{|llllll|}
\hline Período & Crescimento & Crescimento & Redução & Redução & Estagnação \\
& Alta $(>50 \%)$ & Baixa $(<50 \%)$ & Alta $(>50 \%)$ & Baixa $(<50 \%)$ & \\
\hline $1978-1987$ & 433 & 2069 & 29 & 1644 & 1391 \\
\hline $1983-1992$ & 666 & 2321 & 48 & 1451 & 1081 \\
\hline $1988-1997$ & 1230 & 1875 & 176 & 2218 & 67 \\
\hline $1993-2002$ & 867 & 2143 & 149 & 2390 & 17 \\
\hline
\end{tabular}




\begin{tabular}{|llllll|}
\hline $1998-2007$ & 538 & 3262 & 40 & 1703 & 23 \\
\hline $2003-2012$ & 267 & 2998 & 65 & 2205 & 31 \\
\hline Média & 1523 & 2742 & 0 & 1296 & 5 \\
\hline
\end{tabular}
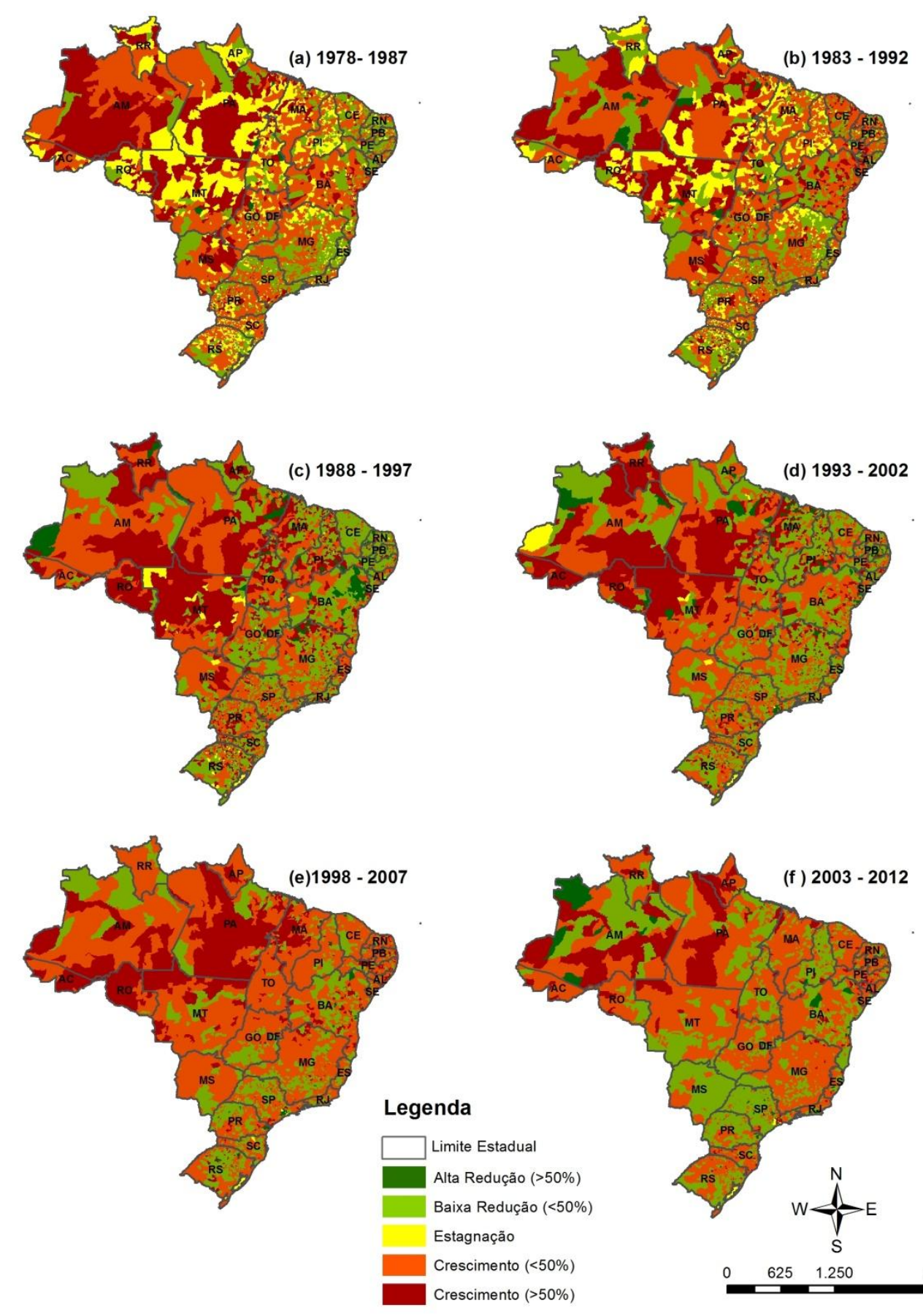

(f) $2003-2012$

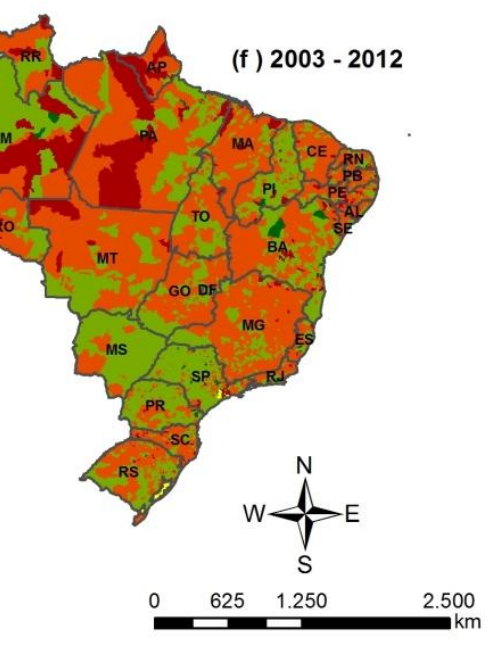

Figura 9. Mapas da taxa de crescimento de produção bovina a partir dos dados absolutos da produção para os seguintes períodos: (a) 1978-1987; (b)1983-1992; (c) 
1988-1997; (d) 1992-2002; (e) 1998-2007 e (f) 2003-2012 a partir de dados absolutos da produção.

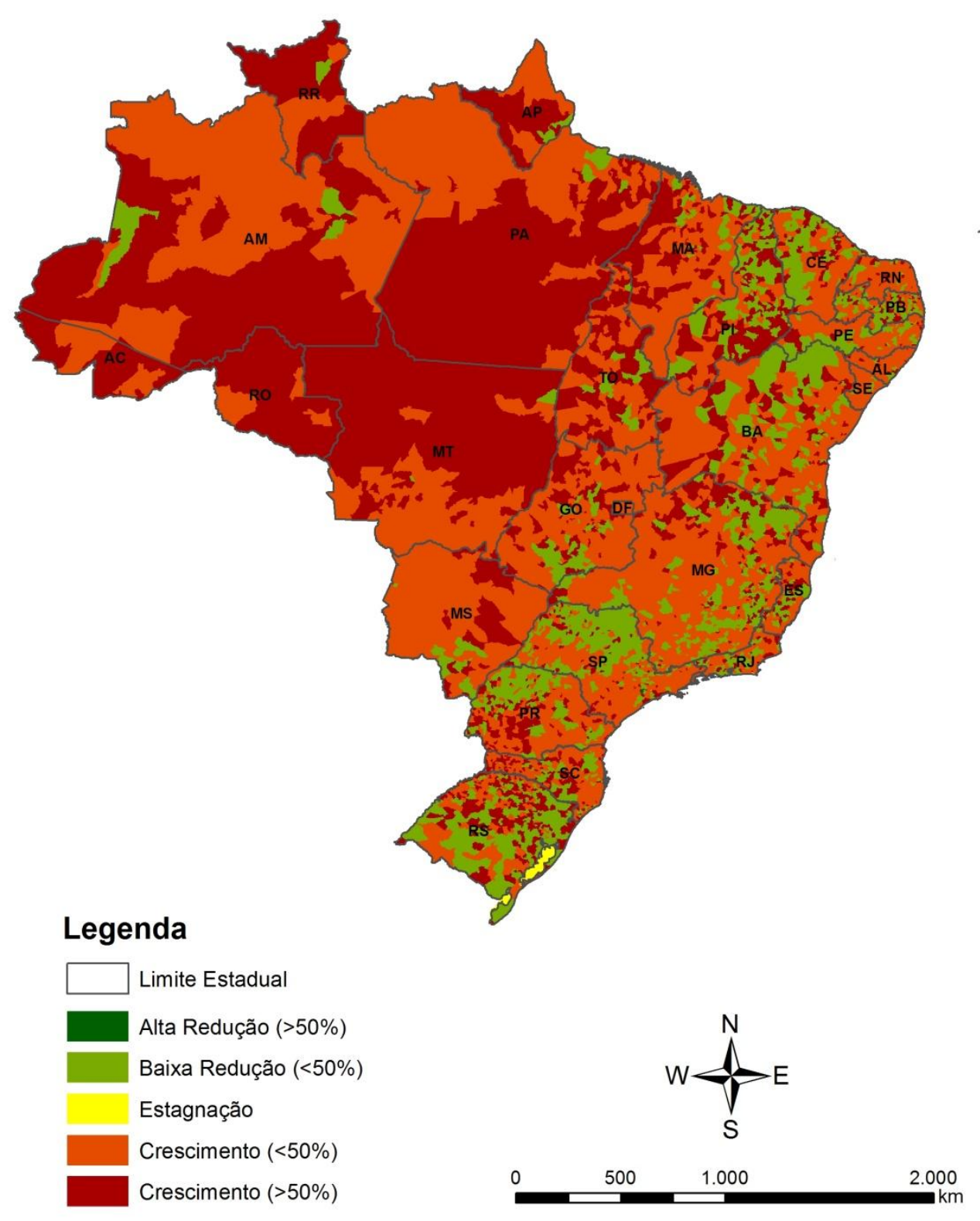

Figura 10. Mapa da taxa média de crescimento da produção bovina no período 19782012 a partir dos dados absolutos da produção. 

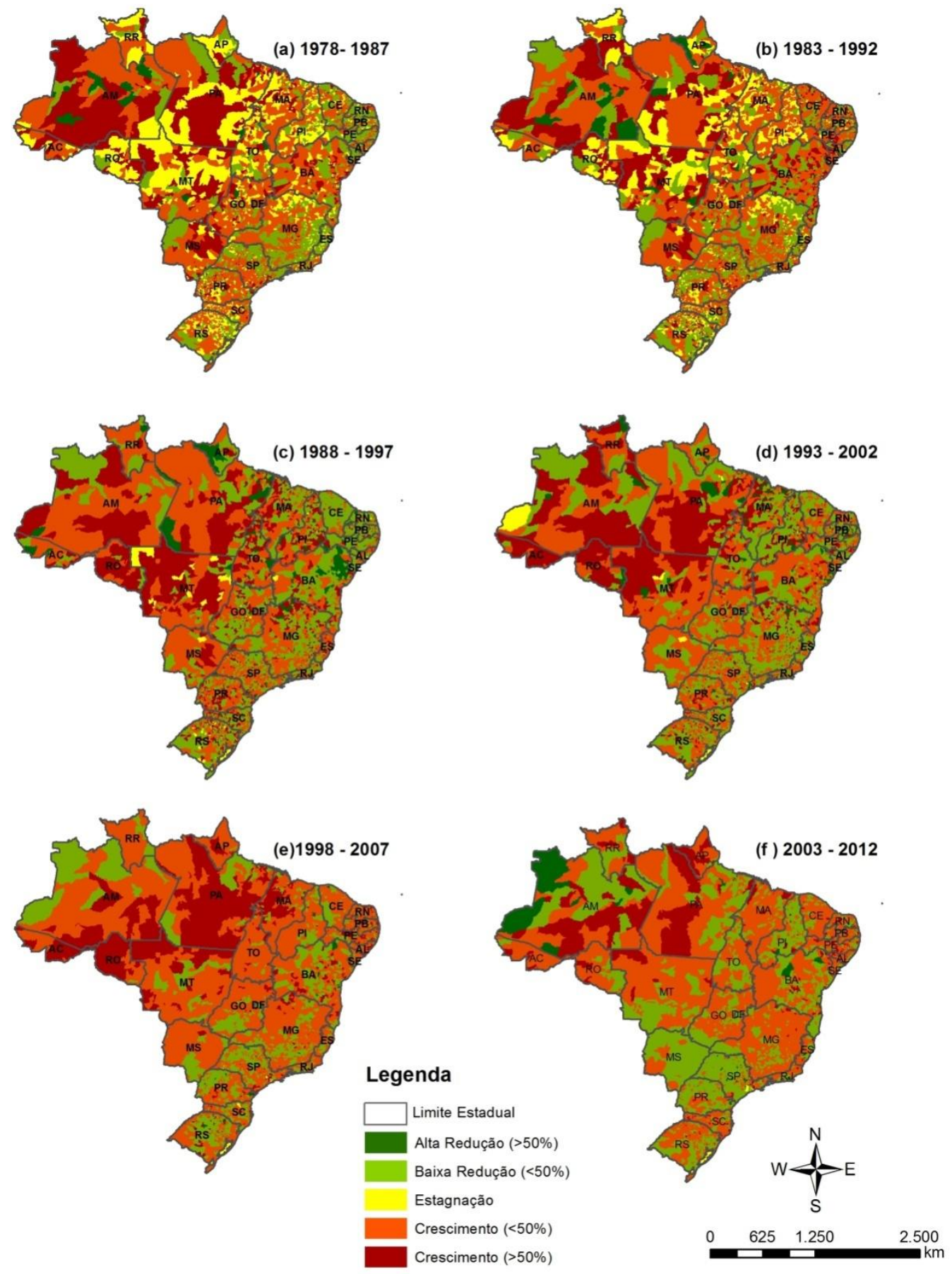

Figura 11. Mapas das taxas de crescimento de produção bovina a partir dos dados normalizados nos seguintes períodos: (a) 1978-1987; (b)1983-1992; (c) 1988-1997; (d) 1992-2002; (e) 1998-2007; (f) 2003- 2012 a partir de dados normalizados da produção. 


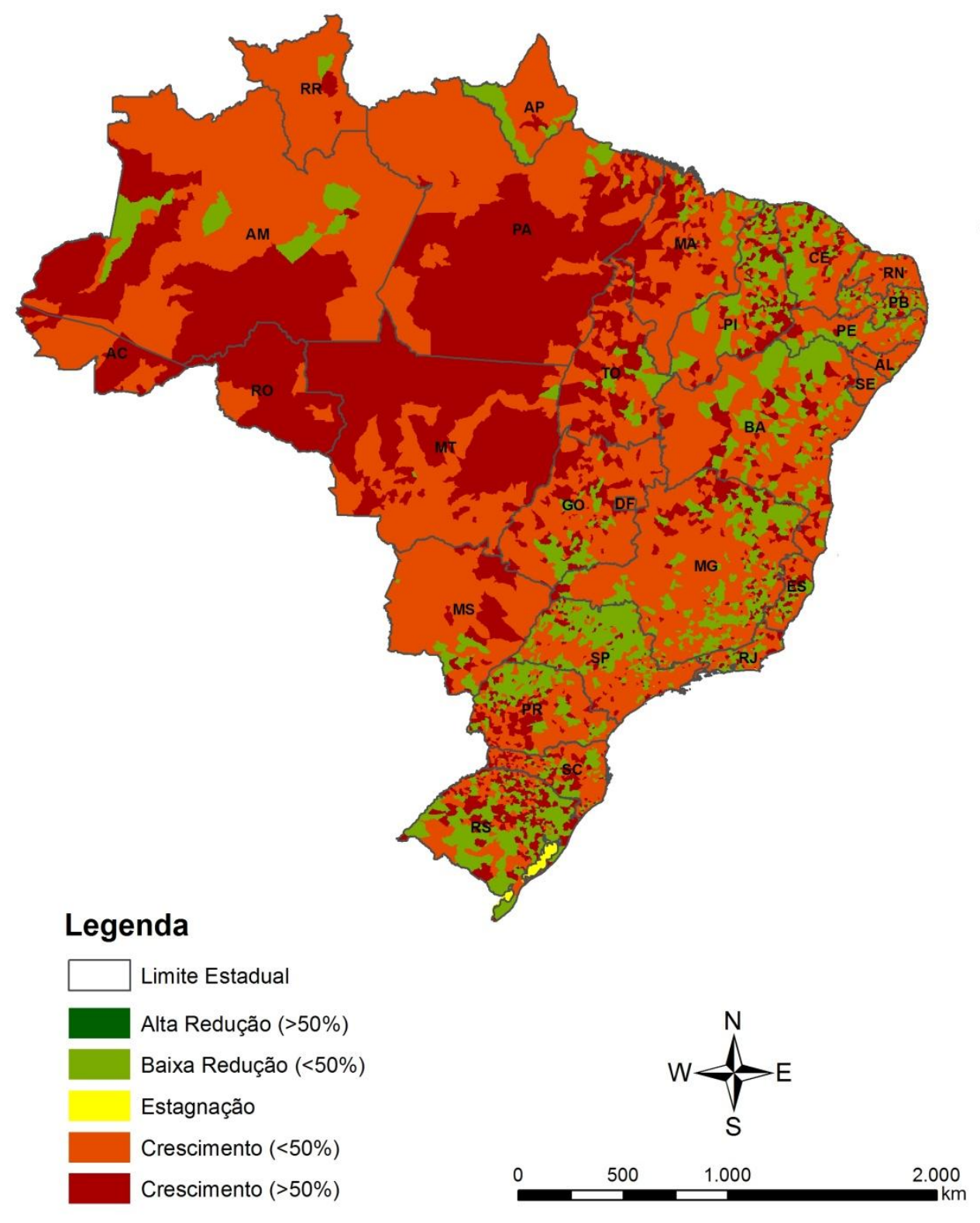

Figura 12. Mapa da taxa média de crescimento de produção bovina no período 19782012 a partir de dados normalizados da produção. 


\subsubsection{Taxa de Crescimento da Produção de Cana de Açúcar (1993 - 2012)}

\section{Resultado com dados absolutos}

O período 1993-2002 (Figura 13) exibiu municípios com redução da taxa de crescimento de produção de cana de açúcar no MA, PI, CE, PR, PE e Maranhão, Piauí, Ceará, Paraíba, Pernambuco e norte da BA. Durante o período 1993-2002 ocorreu o maior número de municípios com alta redução da taxa de crescimento, cerca de 891 municípios (Tabela 3).

Ao contrário dos outros períodos, o período 2003-2012 apresentou grande concentração de municípios com taxa de crescimento de produção de cana de açúcar superior a 50\% nos seguintes Estados: SP, PR, MS, MG, sul do GO e sul do MT. Municípios da região Nordeste (PE, SE, AL, RN, CE, PI, MA e BA) também apresentaram taxa de crescimento superior a $50 \%$.

A taxa média de crescimento de produção de cana de açúcar durante o período de 1993 a 2012 (Figura 13) indicou taxa de crescimento da produção de cana de açúcar superior a $50 \%$ nos municípios no Centro - Sul do país.

Tabela 3. Número de municípios brasileiros conforme o crescimento da produção de cana de açúcar a partir de dados absolutos.

\begin{tabular}{|llllll|}
\hline Período & Crescimento & Crescimento & Redução & Redução & Estagnação \\
& Alta (>50\%) & Baixa $(<50 \%)$ & Alta $(>50 \%)$ & Baixa (<50\%) \\
\hline $1993-2002$ & 1520 & 814 & 891 & 873 & 1464 \\
\hline $1998-2007$ & 1482 & 1103 & 873 & 508 & 1596 \\
\hline $2003-2012$ & 1458 & 1095 & 478 & 1009 & 1525 \\
\hline Média & 2159 & 1227 & 133 & 963 & 1084 \\
\hline
\end{tabular}

\section{Resultado com dados normalizados}

Diferente dos resultados obtidos com os dados absolutos do período 1993-2002 (Figura 13), o emprego de dados normalizados apresentou redução da taxa de crescimento da produção de cana de açúcar não somente em municípios do Nordeste, 
mas também em municípios do Norte do país (Figura 14). O período também apresentou a maior quantidade municípios com alta redução, cerca de 817 municípios (Tabela 4).

O período 1998-2007 destaca a concentração de municípios com taxa de crescimento superior a $50 \%$ em SP. Os dados absolutos e normalizados do período 2003-2012 são concordantes evidenciando a concentração de municípios com taxa de crescimento superior a $50 \%$ em SP, MS, PR, MG, sul do GO.

A média da taxa do crescimento da produção de cana de açúcar (Figura 14) exibiu uma maior quantidade de municípios com redução da taxa de crescimento quando comparada com os dados absolutos. No entanto, também indicou concentração de municípios com taxa de crescimento superior a 50\% nos municípios da região Norte do país e nos estados da região Centro-Sul como São Paulo, Minas Gerais, Goiás, Mato Grosso do Sul e Paraná.

Tabela 4. Número de municípios brasileiros conforme o crescimento da produção de cana de açúcar a partir de dados normalizados.

\begin{tabular}{|llllll|}
\hline Período & Crescimento & Crescimento & Redução & Redução & Estagnação \\
& Alta $(>50 \%)$ & Baixa $(<50 \%)$ & Alta $(>50 \%)$ & Baixa (<50\%) & \\
\hline $1993-2002$ & 1234 & 989 & 817 & 1066 & 1460 \\
\hline $1998-2007$ & 1424 & 1194 & 377 & 970 & 1601 \\
\hline $2003-2012$ & 1447 & 1223 & 299 & 1074 & 1523 \\
\hline Média & 1766 & 1663 & 28 & 1025 & 1084 \\
\hline
\end{tabular}



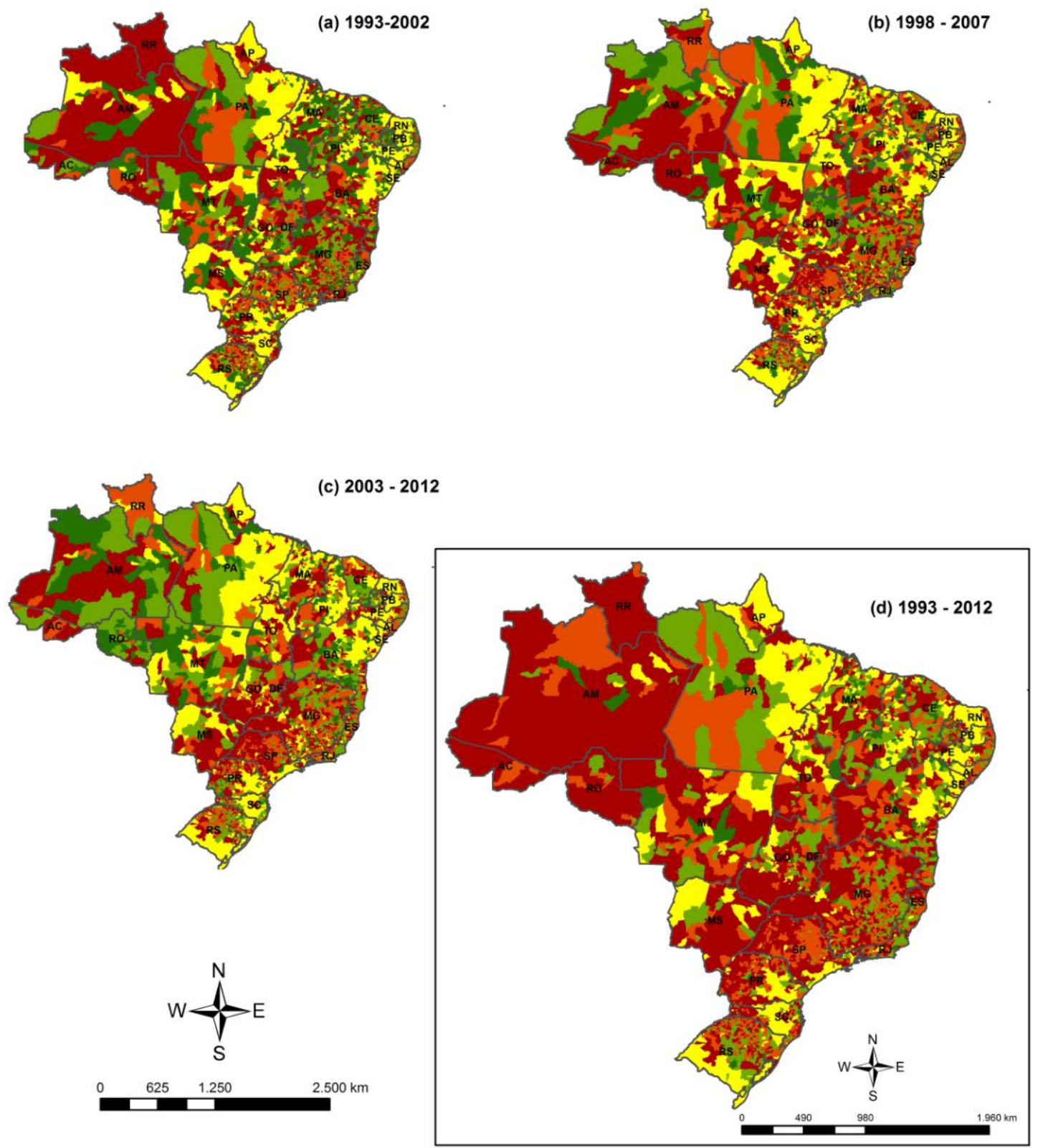

\section{Legenda}

\begin{tabular}{|l|l|l}
\hline Limite Estadual & Baixa Redução $(<50 \%)$ & Crescimento $(<50 \%)$ \\
\hline Estagnação & Alta Redução $(>50 \%)$ & Crescimento $(>50 \%)$
\end{tabular}

Figura 13. Taxa de crescimento da produção de cana de açúcar a partir de dados absolutos da produção para os seguintes períodos: (a) 1993-2002; (b) 1998-2007; (c) 2003-2012; e (d) média da taxa do crescimento da produção de cana de açúcar durante o período 1993-2012 a partir de dados absolutos da produção. 

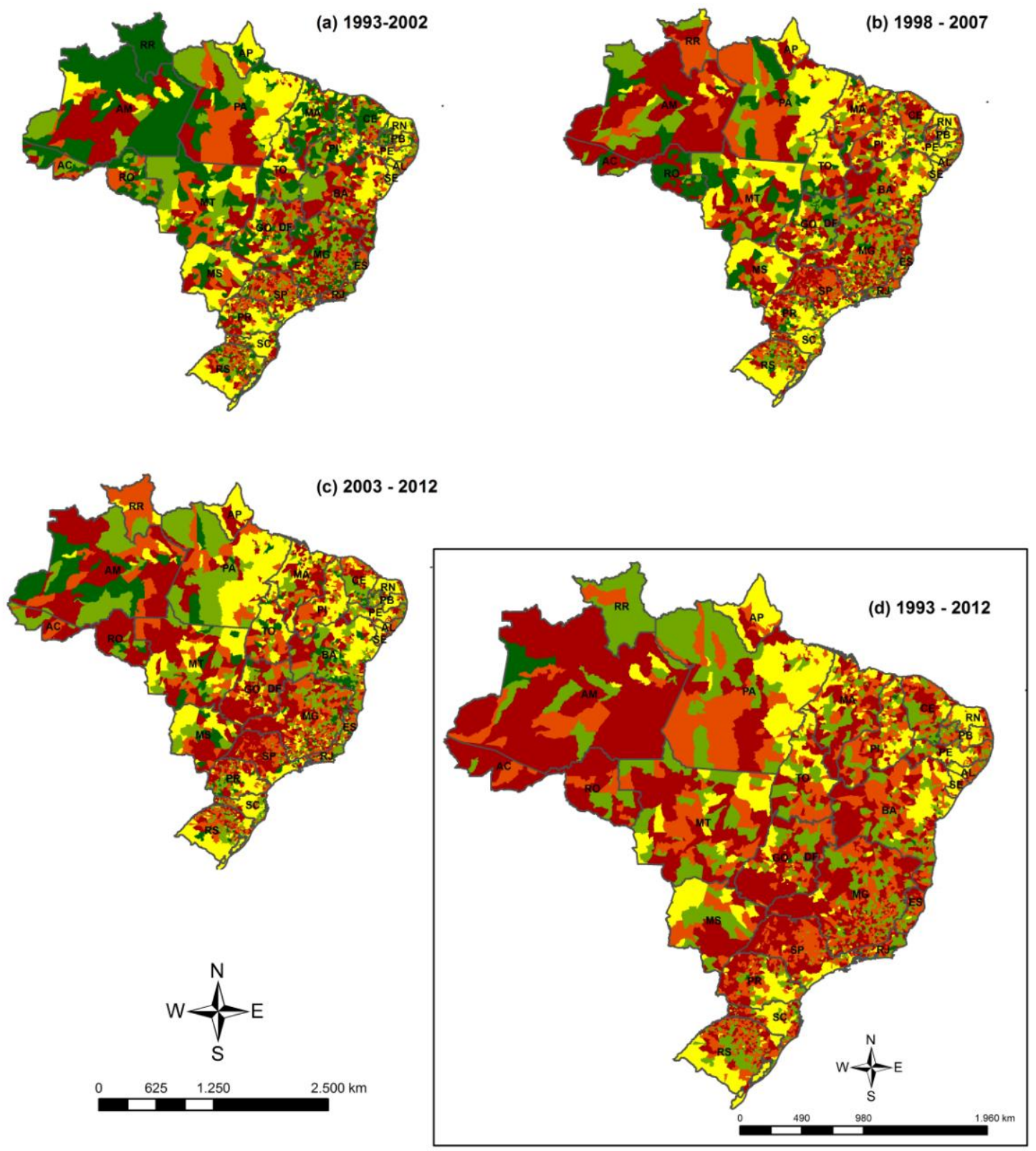

\section{Legenda}

\begin{tabular}{l|ll}
\hline Limite Estadual & Baixa Redução $(<50 \%)$ & Crescimento $(<50 \%)$ \\
Estagnação & Alta Redução $(>50 \%)$ & Crescimento $(>50 \%)$
\end{tabular}

Figura 14. Taxa de crescimento da produção de cana de açúcar a partir de dados normalizados da produção para os seguintes períodos: (a) 1993-2002; (b) 1998-2007; (c) 2003-2012; e (d) média da taxa do crescimento da produção de cana de açúcar durante o período 1993-2012 a partir de dados normalizados da produção. 


\subsubsection{Taxa de Crescimento de Produção de Soja (1993 - 2012)}

\section{Resultados com dados absolutos}

As mais elevadas taxas de crescimento de produção de soja nos períodos 19932002, 1997-2008 e 2003-2012 ocorrem nos municípios da região Sul, Centro-Oeste, Norte (TO, PA, RO, Pará, Rondônia, Sul da AM) e Nordeste (oeste da Bahia, sul do Piauí e sul do Maranhão) (Figura 15).

Durante o período 1993-2002, os municípios do RS, MS, MG e SP apresentaram redução da taxa de crescimento de produção de soja. O período 1997-2008 conteve a maior presença de municípios com taxa de crescimento de produção de soja superior a 50\%, em relação aos outros períodos. A taxa de crescimento é superior a 50\% para 1328 municípios durante este período (Tabela 5) nos seguintes Estados: RS, SC, MS, SP, oeste de MG, GO, MT, TO, oeste da BA, sudoeste do PI, sul do MA, PA e também em RO, RR e AC.

No período 2003-2012, notou-se alta redução e baixa redução do crescimento da produção de soja nos municípios do MS, SP, MG e do sul do GO.

Na média da taxa de crescimento de produção de soja, as regiões Sul e Centro Oeste se destacaram e apresentaram grande quantidade de municípios com taxa de crescimento de produção de soja superior a 50\% (Figura 15). Os municípios da região Sudeste (MG e SP); Nordeste (oeste da BA, sul do PI, sul do MA); Norte (TO, PA, sul da AM, RO, AC e RO) apresentaram também taxa de crescimento de produção superior a $50 \%$.

Tabela 5. Número de municípios brasileiros conforme o crescimento da produção de soja a partir de dados absolutos.

\begin{tabular}{|llllll|}
\hline Período & Crescimento & Crescimento & Redução & Redução & Estagnação \\
& Alta $(>50 \%)$ & Baixa $(<50 \%)$ & Alta $(>50 \%)$ & Baixa $(<50 \%)$ & \\
\hline $1993-2002$ & 953 & 371 & 316 & 325 & 3594 \\
\hline $1998-2007$ & 1328 & 484 & 105 & 243 & 3404 \\
\hline $2003-2012$ & 720 & 738 & 398 & 359 & 3350 \\
\hline Média & 1547 & 525 & 23 & 271 & 3200 \\
\hline
\end{tabular}




\section{Resultados com dados normalizados}

Os mapas destacaram pequenas diferenças em relação os mapas com dados absolutos, os resultados normalizados apresentaram maior número de municípios com baixa redução da taxa do crescimento em todos os períodos analisados (Tabela 6). Contudo, de maneira geral, os resultados foram próximos aos resultados ocorridos com dados absolutos.

As taxas de crescimento da produção de soja nos períodos 1993-2002, 19972008 e 2003-2012 estiveram superiores a 50\% nos municípios dos Estados do RS. SC, PR, MS, GO, porção oeste de MG, MT, TO, MA, oeste da BA, PI, RO e PA (Figura 16). No período 2003-2012 os municípios de SP, MG e MS apresentaram baixa redução e alta redução da taxa de crescimento (superior a 50\%).

O mapa da média taxa de crescimento de produção de soja com dados normalizados (Figura 16) apresentou um resultado mais suavizado, com um número menor de municípios com taxa de crescimento superior a 50\%. Todavia, assim como nos dados absolutos, as taxas de crescimento superiores a 50\% concentraram-se em municípios da região Sul, Centro- Oeste e nos estados de MG, SP, TO, MA, PI e oeste da BA.

Tabela 6. Número de municípios brasileiros conforme o crescimento da produção de soja a partir de dados normalizados.

\begin{tabular}{|llllll|}
\hline Período & $\begin{array}{l}\text { Crescimento } \\
\text { Alta (>50\%) }\end{array}$ & Crescimento & Redução & Redução & Estagnação \\
\hline $1993-2002$ & 735 & 593 & Alta $(>50 \%)$ & Baixa (<50\%) & \\
\hline $1998-2007$ & 970 & 630 & 87 & 524 & 3577 \\
\hline $2003-2012$ & 629 & 890 & 163 & 534 & 3399 \\
\hline Média & 963 & 1079 & 4 & 334 & 3186 \\
\hline
\end{tabular}



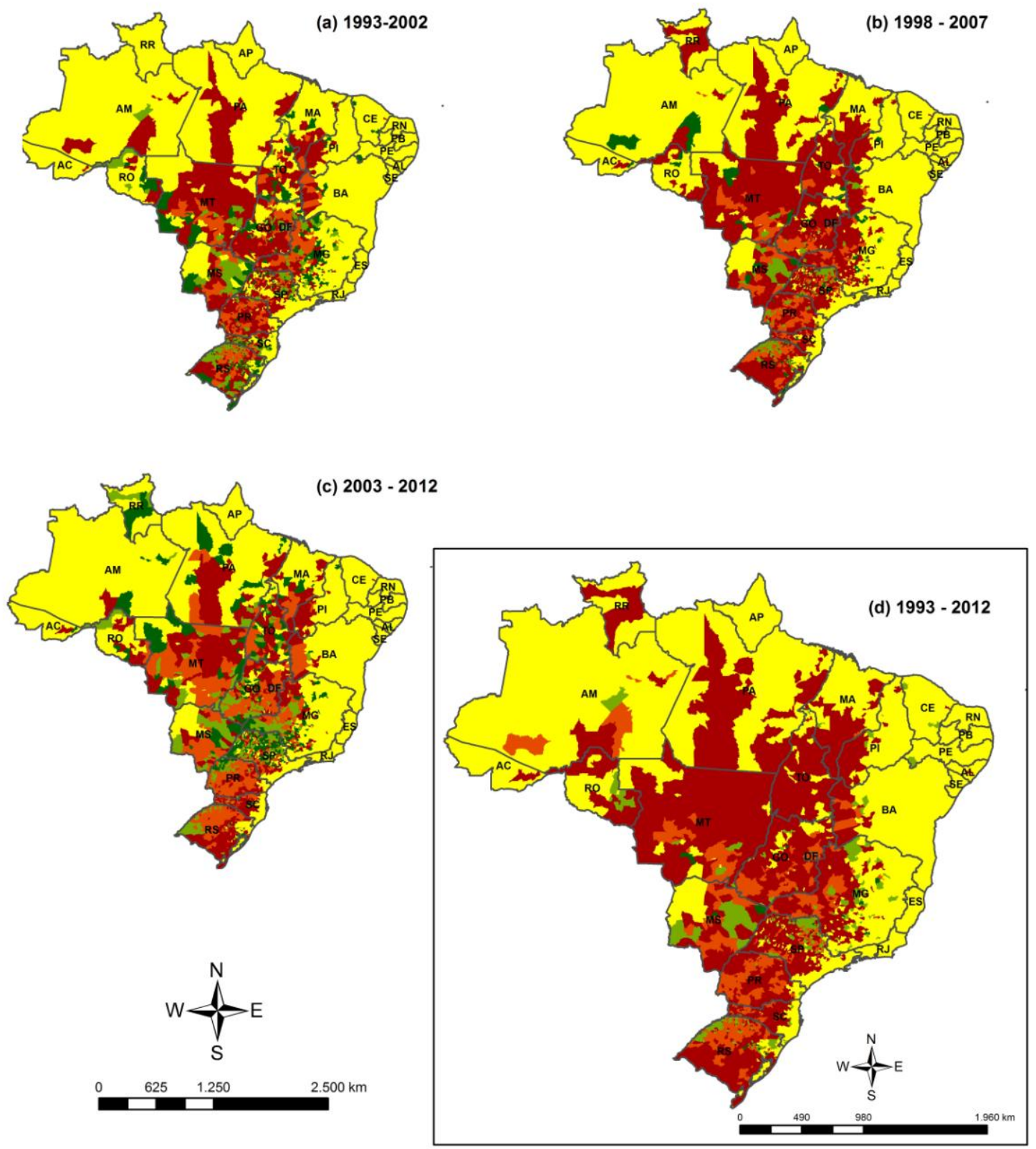

\section{Legenda}
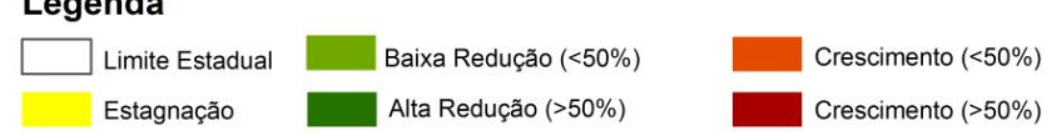

Figura 15. Taxa de crescimento de produção de soja a partir de dados absolutos da produção para os seguintes períodos: (a) 1993-2002; (b) 1998-2007; (c) 2003-2012; e (d) média da taxa de crescimento de produção de soja durante o período 1993-2012 a partir de dados absolutos da produção. 

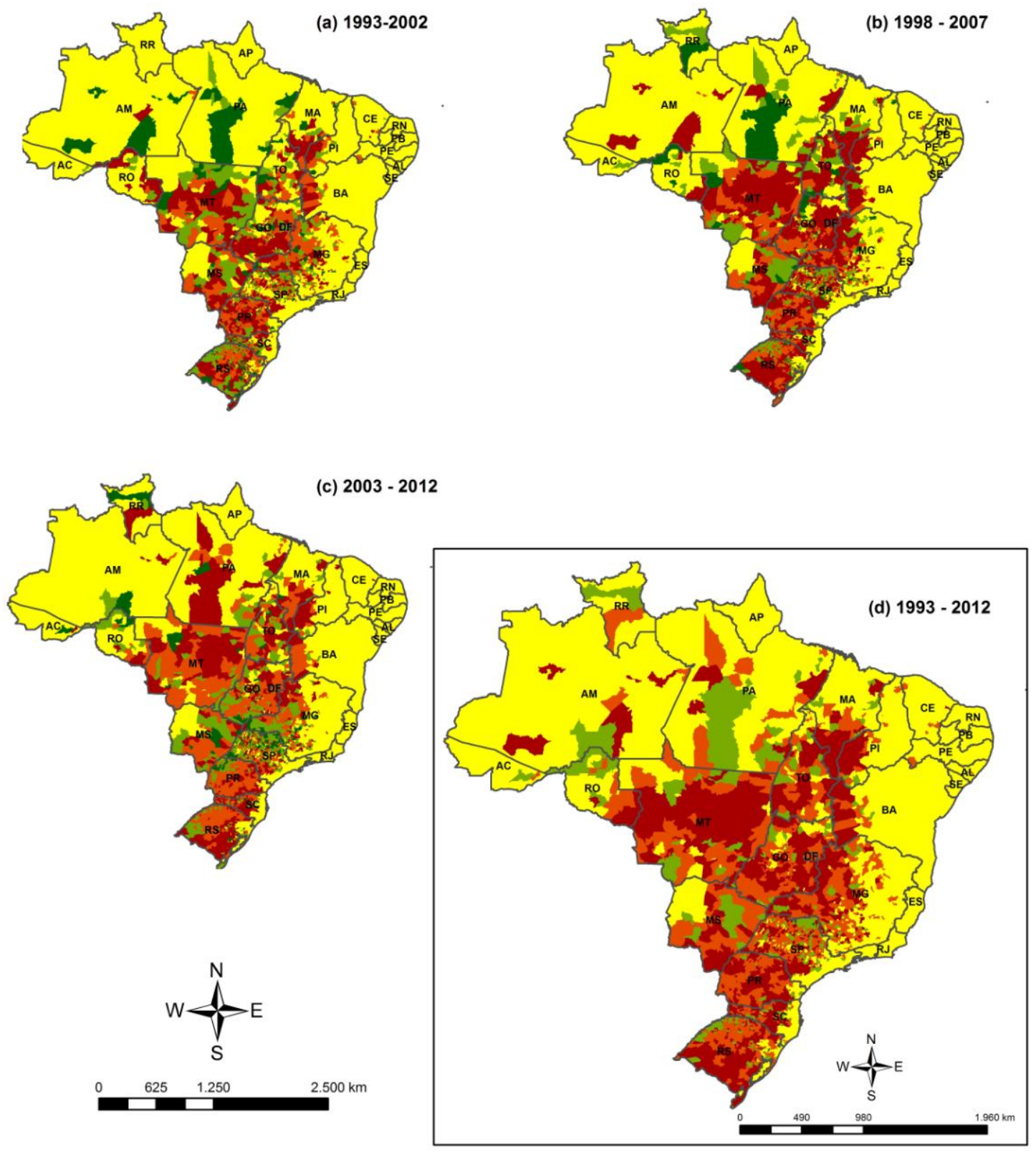

\section{Legenda}
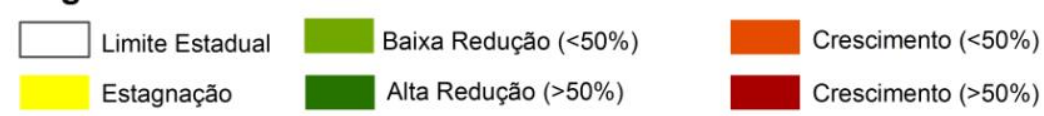

Figura 16. Taxa de crescimento de produção de soja a partir de dados normalizados da produção para os seguintes períodos: (a) 1993-2002; (b) 1997-2008; (c) 2003-2012; e (d) média taxa de crescimento de produção de soja durante o período 1993-2012 a partir de dados normalizados da produção. 


\subsubsection{Taxa de Crescimento de Produção de Milho (1993 - 2012)}

\section{Resultados com dados absolutos}

No período 1993-2002 observou-se alta redução da taxa de crescimento (superior a 50\%) em municípios do MA, PI, RN, PB, PE, AL, SE e norte da BA (Figura 17). Em relação aos outros períodos, o período 1997-2008 apresentou o maior número de municípios com taxa de crescimento superior a 50\%, atingindo 1684 municípios (Tabela 7).

O período "c" de 2003 a 2012 apreendeu com maior clareza a concentração de municípios com taxas de crescimento superiores a $50 \%$ na região Centro - Oeste, principalmente no estado do MT. Porção considerável de municípios com taxa de crescimento superior a $50 \%$ pôde ser vista no MA, PI, BA, PE e TO. O mesmo resultado também foi visto nos municípios entre GO e MG e nos municípios da região Sul (PR, SC e RS). Os municípios do MS e SP apresentaram, no mesmo período, redução da taxa de crescimento.

O mapa da média da taxa de crescimento de produção de milho entre 1993 e 2012 aponta maior concentração de municípios do MT e MS com taxa de crescimento superior a 50\% (Figura 17). Taxas de crescimento superiores a 50\% puderam ser vistas nos municípios de MG, GO, PI, MA, PE, SE, AL, BA e nos municípios da região Norte do país.

Tabela 7. Número de municípios brasileiros conforme o crescimento da produção de milho a partir de dados absolutos.

\begin{tabular}{|llllll|}
\hline Período & Crescimento & Crescimento & Redução & Redução & Estagnação \\
& Alta (>50\%) & Baixa $(<50 \%)$ & Alta (>50\%) & Baixa (<50\%) & \\
\hline $1993-2002$ & 1470 & 1217 & 1005 & 1801 & 71 \\
\hline $1997-2008$ & 1684 & 1619 & 499 & 1652 & 108 \\
\hline $2003-2012$ & 1095 & 1572 & 668 & 2055 & 170 \\
\hline Média & 1545 & 2091 & 92 & 1784 & 54 \\
\hline
\end{tabular}




\section{Resultado com dados normalizados}

Os resultados dos mapas com dados normalizados nos períodos 1993-2002, 1997-2008 e 2003-2012 não apresentaram grandes oposições aos resultados dos mapas com dados absolutos. A tabela 8 confirma a similaridade entre os resultados.

O mapa da média da taxa de crescimento de produção de milho durante o período de 1993 a 2012 apresentou taxas de crescimento da produção de milho superiores a $50 \%$ em muitos municípios da região Centro-Oeste, Nordeste e Norte (Figura 18).

Tabela 8. Número de municípios brasileiros conforme o crescimento da produção de milho a partir de dados normalizados.

\begin{tabular}{|llllll|}
\hline Período & Crescimento & Crescimento & Redução & Redução & Estagnação \\
& Alta (>50\%) & Baixa $(<50 \%)$ & Alta (>50\%) & Baixa (<50\%) \\
\hline $1993-2002$ & 1162 & 1308 & 1027 & 1998 & 71 \\
\hline $1998-2007$ & 1633 & 1653 & 473 & 1702 & 105 \\
\hline $2003-2012$ & 1192 & 1616 & 551 & 2039 & 167 \\
\hline Média & 1279 & 2282 & 60 & 1891 & 54 \\
\hline
\end{tabular}



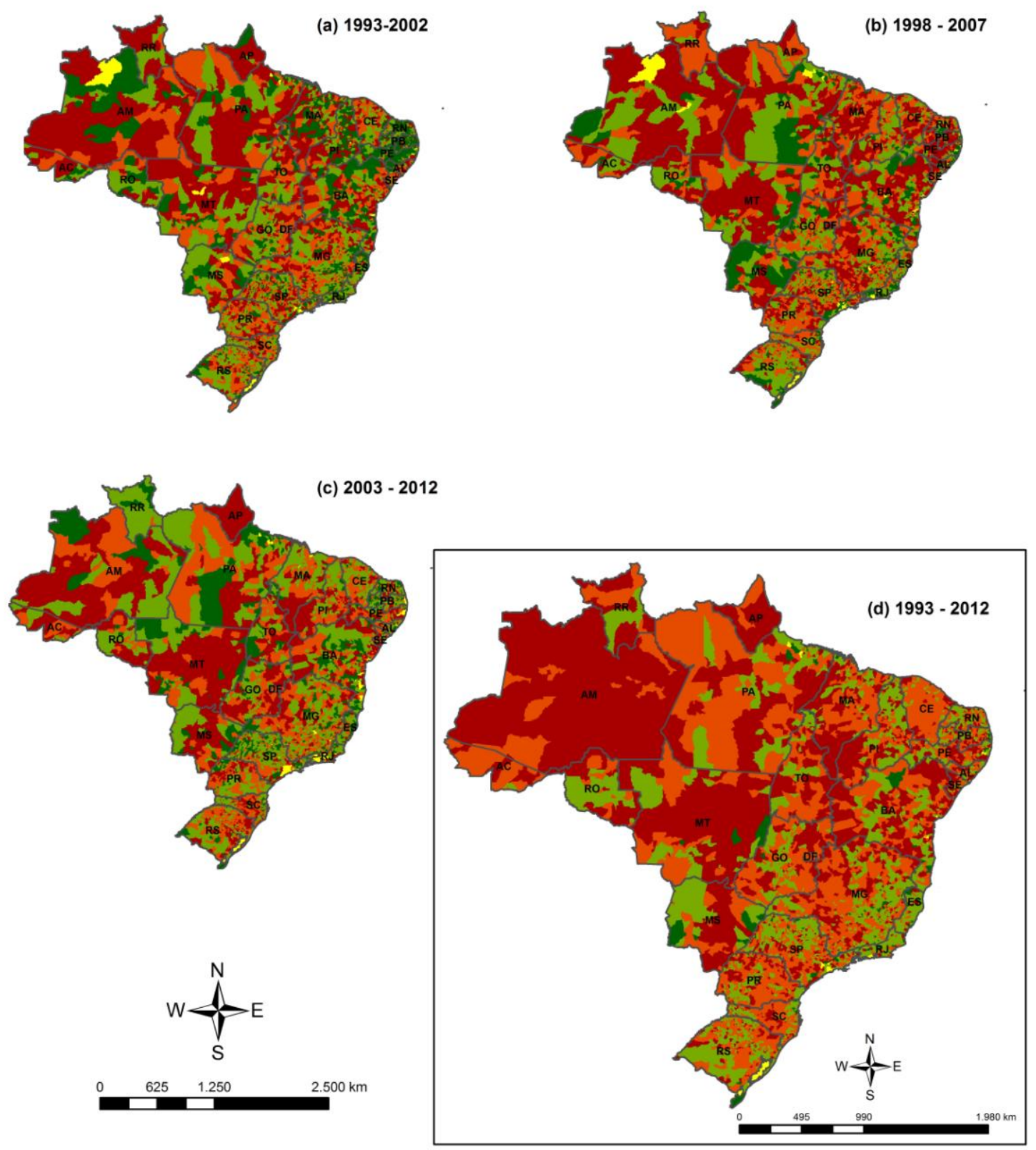

\section{Legenda}

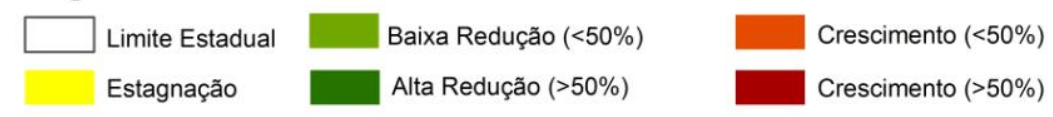

Figura 17. Taxa de crescimento de produção de milho a partir dos dados absolutos da produção para os seguintes períodos: (a) 1993-2002; (b) 1997-2008; e (c) 2003-2012; e (d) média da taxa de crescimento de produção de milho durante o período de 1993 a 2012 a partir de dados absolutos da produção. 

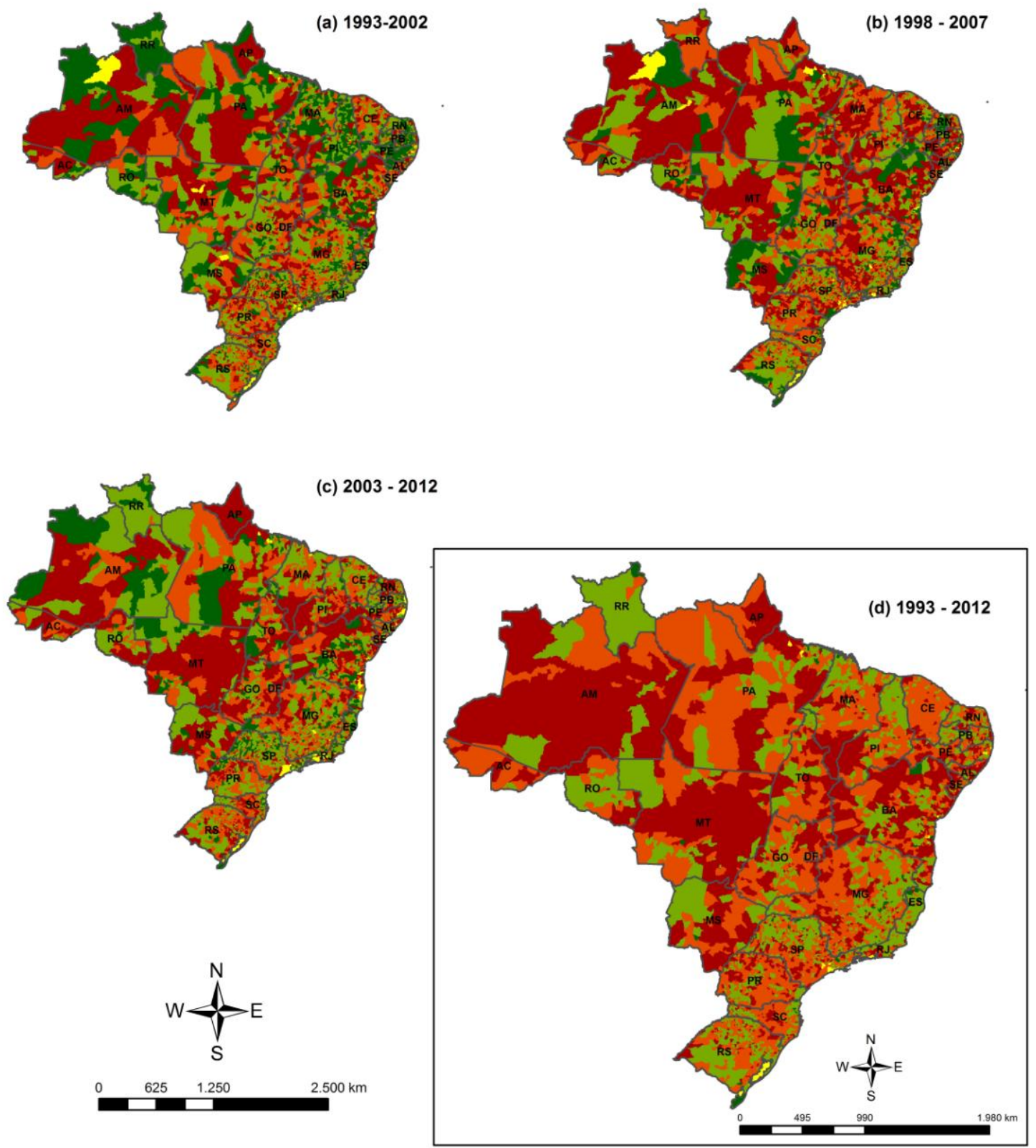

\section{Legenda}

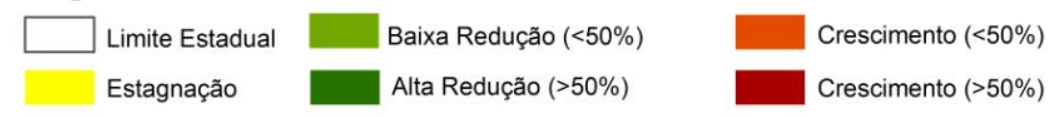

Figura 18. Taxa de crescimento de produção de milho a partir dos dados normalizados da produção para os seguintes períodos: (a) 1993-2002; (b) 1997-2008; e (c) 20032012; e (d) média da taxa de crescimento de produção de milho durante o período de 1993 a 2012 a partir de dados normalizados da produção. 


\subsection{Mapas de Aceleração da Produção}

\subsubsection{Mapas de Aceleração da Produção Bovina (1978-2012)}

\section{Resultados com dados absolutos}

No período 1978-1992 a aceleração da produção foi observada principalmente em municípios de MS, mas também em municípios de MT, GO, PA e RO (Figura 19). O período 1988-1997 indicou aceleração mais intensa nos municípios dos Estados descritos anteriormente e nos municípios do PA e RS.

No período 1988-1997 notou-se desaceleração da produção bovina nos municípios da parte leste dos estados do PA, MG, na parte oeste de GO e MS.

No período 1993-2002 observou-se a aceleração do crescimento nos municípios do PA, RO e AC. Os municípios de MT e MS tiveram desaceleração. A aceleração da produção nos municípios da região Norte aumenta no período 1998-2007, principalmente em RO, na parte sul da AM, MA e PA. A aceleração também vista nos municípios de MS, como em Corumbá, e em municípios da porção norte do MT.

O período 2003-2012 destacou a desaceleração da produção em diversos municípios da região Centro-Oeste e Norte do país, principalmente em MT, MS, RO e na porção leste do PA. Entretanto, ocorreu a aceleração da produção bovina no município de Lábrea na porção sul da AM, São Felix do Araguaia na região nordeste de MT e em Rio Verde no GO.

A aceleração média da produção bovina (Figura 19) entre o período 1978-2012 indicou um aumento nos municípios da região Norte e Centro Oeste do país, principalmente nos municípios de Nova Mamoré (RO), Lábrea (AM), Altamira (PA), São Felix do Xingu (PA), Itaituba (PA), Colniza (MT), Corumbá (MS) e Crixás (GO). A desaceleração da produção bovina ocorreu principalmente nos municípios do MS, MT, GO, MG e leste do PA.

\section{Resultados com dados normalizados}

Os resultados da aceleração da produção bovina com dados normalizados salientaram os efeitos de aceleração ou desaceleração de produção dos municípios 
(Figura 20). Os resultados não destacaram a aceleração de produção dos municípios da região Norte da mesma forma que os dados absolutos.

O período 1988-1997 ressaltou a desaceleração em municípios do Nordeste, como no CE, PB, PE, AL, SE e BA. A partir do período 1993-2002 a região Nordeste retoma a aceleração de produção, sobretudo em municípios na porção norte da BA. Esse período também indica a desaceleração nos municípios do Centro-Sul do país, como no MS e em SP.

O mapa 1998-2007 aponta um período de aceleração do crescimento da produção bovina em várias partes do país, principalmente em municípios da parte leste do PA, MA, TO, RO, GO, RS, ES, MG, sul da BA e outros municípios do Nordeste.

Destaca-se grande desaceleração do crescimento em municípios do MS, SP, MT, RO, PA, sul da BA no período 2003 -2012. A aceleração do crescimento nesse intervalo de tempo ocorreu nos municípios do GO, MG, ES, RJ, RS, SC e em municípios do Nordeste.

O mapa da média da aceleração do crescimento com dados normalizados durante o período 1978-2012 apontou forte desaceleração na região Centro - Sul do país, compreendendo os estados de SP, MS, PR, MG (porção oeste) e GO (porção sul) (Figura 20). A desaceleração também ocorreu nos municípios da porção leste do PA, no MA, TO, BA e RJ.

Observou-se também no mapa da média da taxa de crescimento de produção bovina aceleração do crescimento nos municípios do ES, MG, norte do MT, RO, PA, MA, GO, RS, SC, PE, AL e SE. 

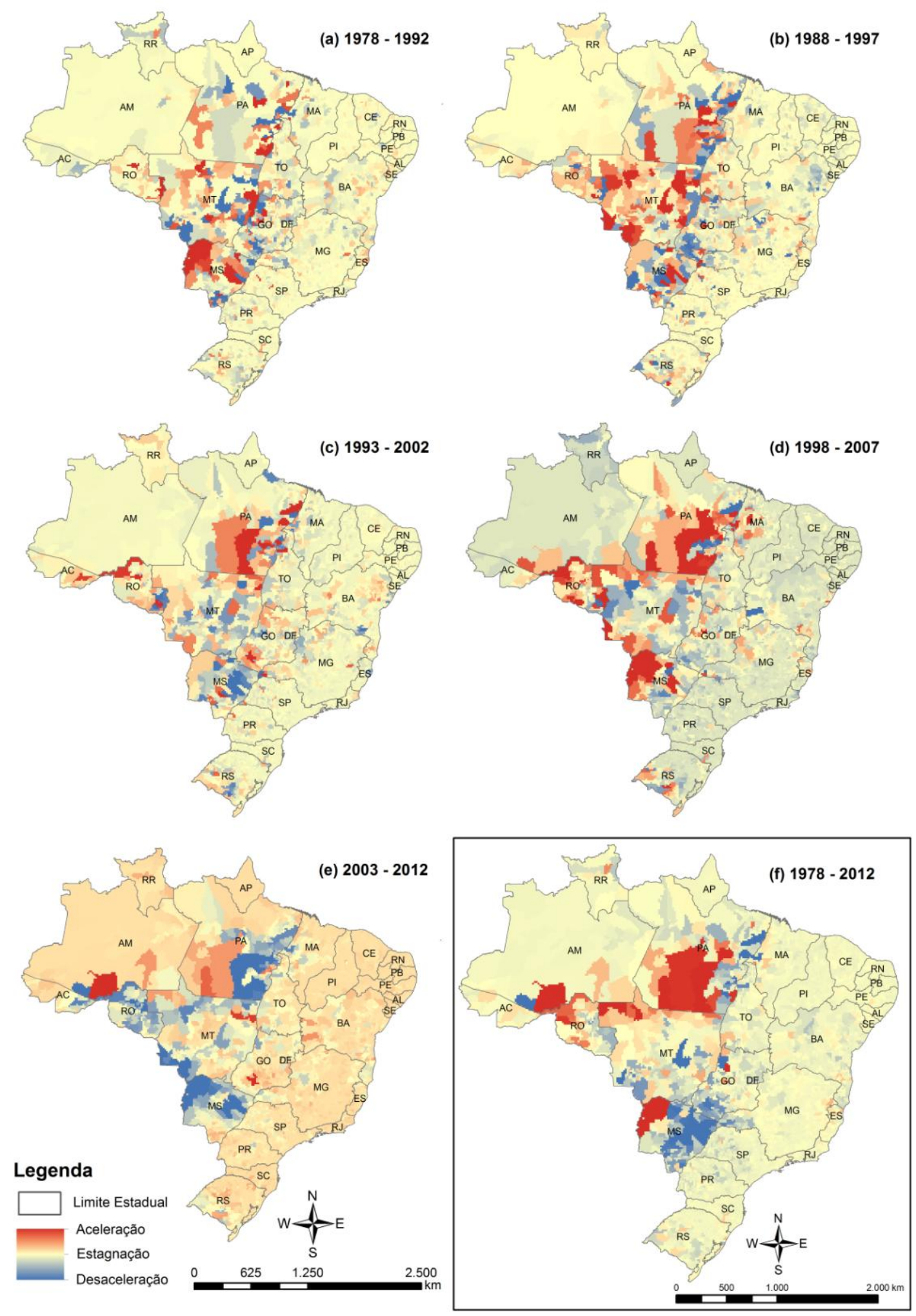

Figura 19. Mapas de aceleração da produção bovina a partir de dados absolutos nos seguintes períodos: (a) 1978-1992; (b) 1988-1997; (c) 1993-2002; (d) 1998-2007; (e) 2003-2012; e (f) aceleração média da produção bovina durante o período 1978-2012 a partir de dados absolutos. 

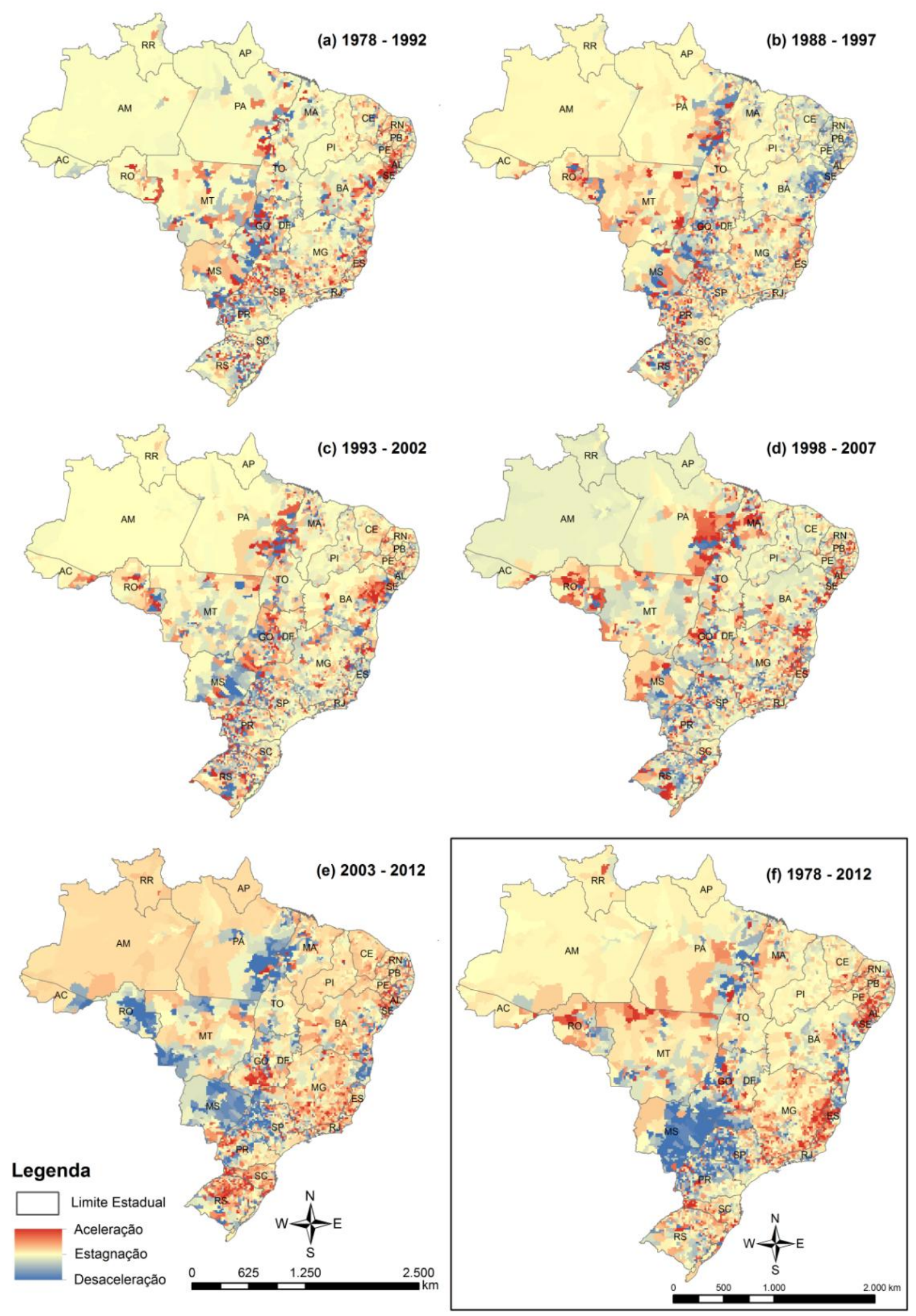

Figura 20. Mapas de aceleração da produção bovina a partir de dados normalizados para os seguintes períodos: (a) 1978-1992; (b) 1988-1997; (c) 1993-2002; (d) 19982007; (e) 2003-2012; e (f) aceleração média de produção bovina durante o período 1978-2012 a partir dos dados normalizados da produção. 


\subsubsection{Mapas de Aceleração da Produção de Cana de Açúcar (1993-2012)}

\section{Resultados com dados absolutos}

O período 1993-2007 destacou aceleração do crescimento da produção de cana de açúcar em municípios de SP, MG, sul do GO, MS e MT (Figura 21). Foi apontada também a aceleração em municípios na porção leste do Nordeste, como em PE, PB, RN e desaceleração do crescimento da produção em AL. Os estados do RJ e ES também apresentaram municípios com aceleração do crescimento.

No período 2003-2012 a aceleração da produção de cana de açúcar apareceu de maneira mais intensa em um maior número de municípios do MS, SP, MG, GO, PR e no sul do AM. A desaceleração foi indicada nos municípios de MT, RN, PB, PE, RJ e ES. Os municípios de AL apresentaram aceleração.

O mapa da aceleração média de produção de cana de açúcar (Figura 21) destaca aumento nos municípios dos estados do Centro- Sul e também no MA, sul da BA e norte do ES. A desaceleração do crescimento da produção foi observada nos municípios da região Nordeste como nos estados de PE e AL e em municípios de MT e RJ.

\section{Resultados com dados normalizados}

O período 1993-2007 bem como o período 2003-2012 apresentaram resultados próximos aos dos mapas da aceleração do crescimento com dados absolutos, a concentração de municípios com aceleração do crescimento pôde ser vista nos estados do PA, SP, MS, MG e GO (Figura 22).

O mapa da aceleração média no período 1993-2012 indicou aumento nos municípios de SP, MG, PR, MS, GO, norte do ES e sul da BA (Figura 22). 
(a) 1993- 2007

(b) $2003-2012$
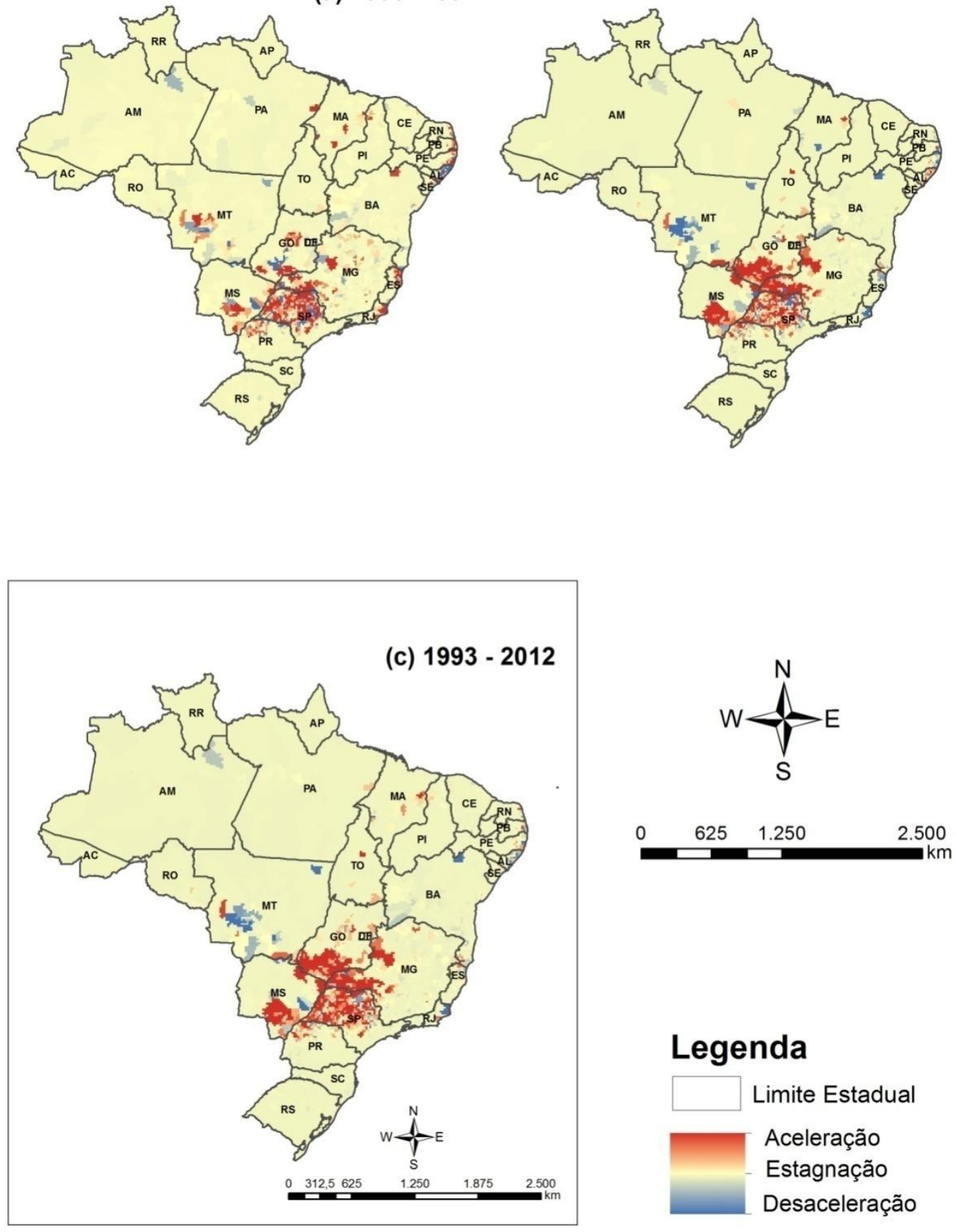

\section{Legenda}

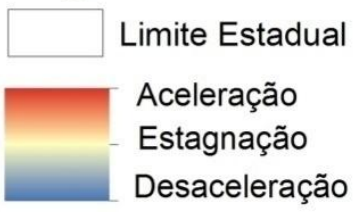

Figura 21. Mapas de aceleração de produção de cana de açúcar a partir dos dados absolutos para os seguintes períodos: (a) 1993-2007; (b) 2003-2012; e (c) aceleração média da produção de cana de açúcar durante o período 1993-2012 a partir de dados absolutos. 

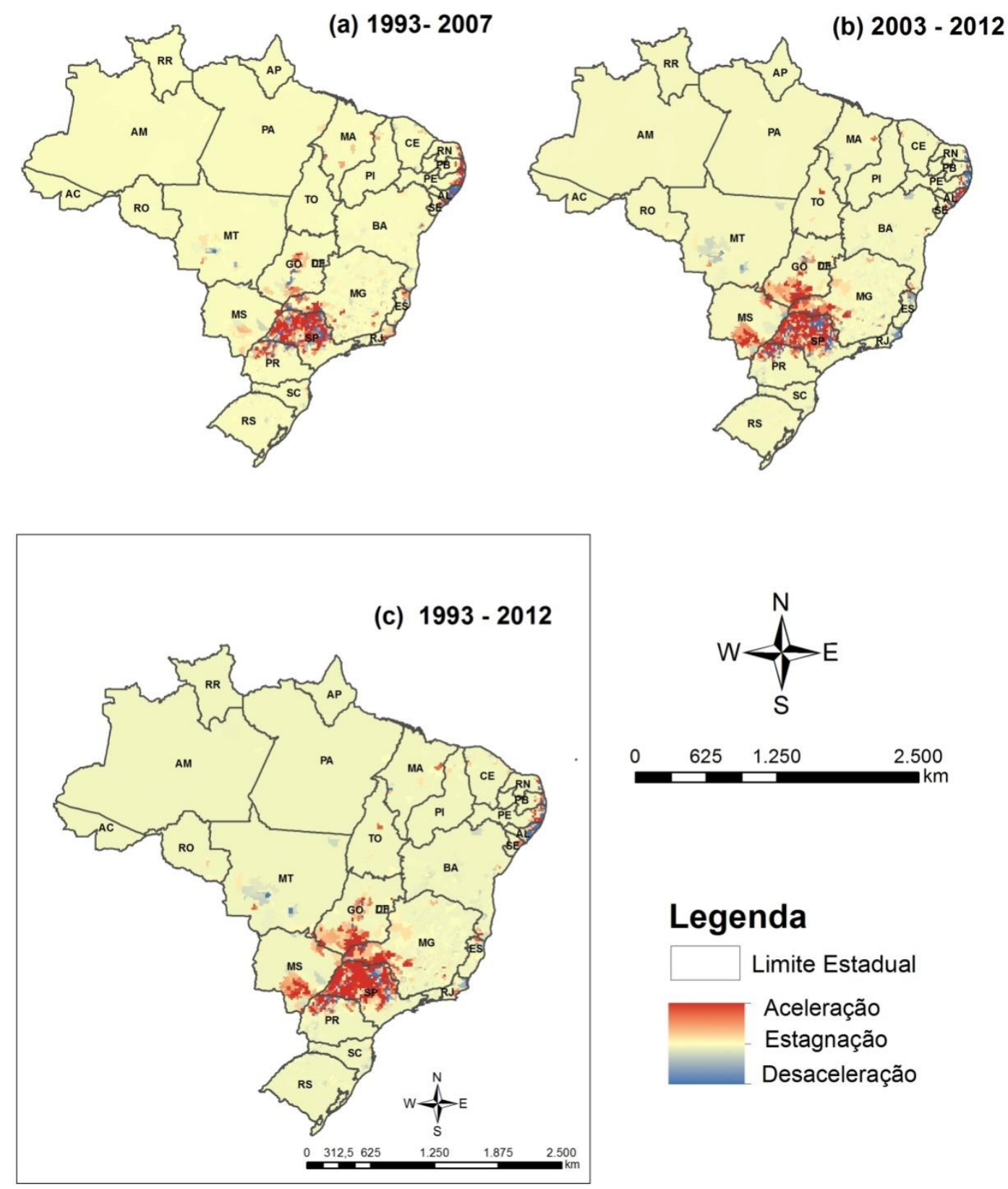

Figura 22. Mapas de aceleração de produção de cana de açúcar a partir de dados normalizados para os períodos de (a) 1993-2007; (b) 2003-2012; e (c) aceleração média da produção de cana de açúcar durante o período 1993-2012 a partir de dados normalizados. 


\subsubsection{Mapas de Aceleração da Produção de Soja (1993-2012)}

\section{Resultados com dados absolutos}

O período 1993-2007 apresentou aceleração de produção em municípios próximos da divisa entre GO e MG, nos municípios de MT, oeste da BA, PI, MA e TO (Figura 23). No período 2003-2007 houve desaceleração em municípios de MT, GO, MS, MG e BA.

O mapa de aceleração média de crescimento de produção de soja durante o período 1993-2012 apontou que houve aceleração da produção nos municípios próximos a divisa entre MG e GO, no oeste da BA, MT e PI (Figura 23). A desaceleração do crescimento foi observada no sul de GO, MG, oeste da BA e em alguns municípios de MT.

\section{Resultados com dados normalizados}

O período 1993-2007 indicou aceleração do crescimento da produção de soja nos municípios do estado do RS, SC, PR, MAS, MG, MT, TO, BA, PI e MA (Figura 24). Também foi observada a desaceleração do crescimento em alguns municípios do RS, PR, sul do GO, MT e BA.

No período seguinte 2003-2012, os municípios do MT, sul do MS, norte do PR, MG, sul do GO e SP apresentaram forte desaceleração do crescimento da produção bovina. A aceleração da produção esteve presente no RS, SC, PR e em alguns municípios do MT, GO, BA, PI e MS.

O mapa de aceleração média com dados normalizados indicou que a aceleração da produção durante o período 1993- 2012 se deu principalmente na região Sul (RS, SC e PR), na região Centro Oeste, principalmente no estado do MT, na divisa entre o GO e MG, e na região Norte e Nordeste como nos municípios do TO, PI e oeste da BA (Figura 24). O mapa aponta suave aceleração da produção nos estados do MA e na parte leste do PA. A desaceleração do crescimento esteve presente nos municípios da parte norte do PR, sul do GO, MG, oeste da BA e municípios do MT. 
(a) 1993- 2007

(b) $2003-2012$
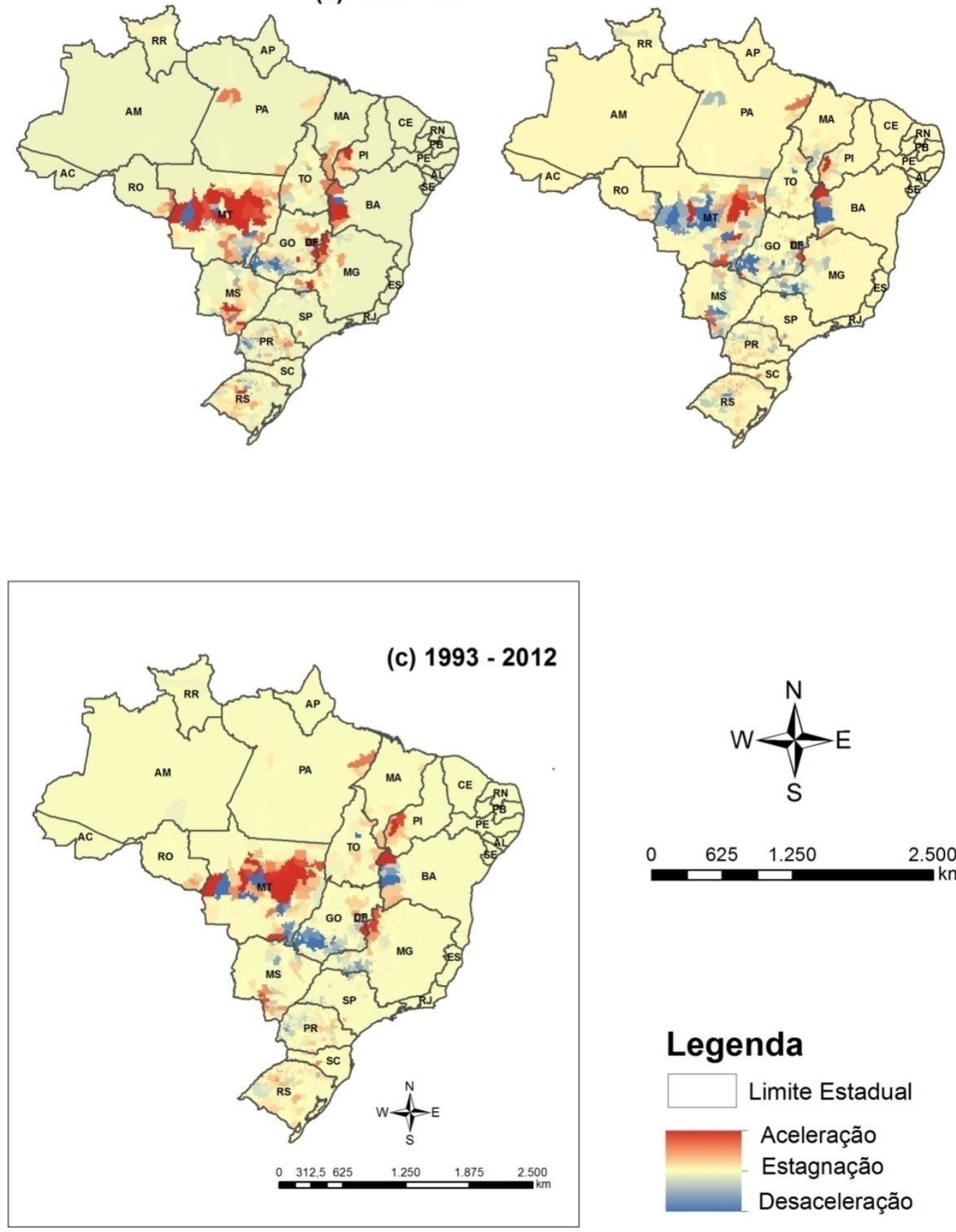

\section{Legenda}

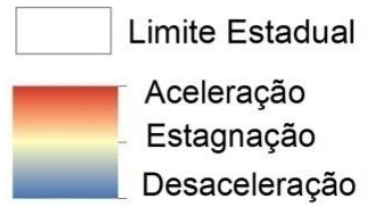

Figura 23. Mapa de aceleração da produção de soja a partir dos dados absolutos da produção: (a) 1993 - 2007; (b) 2003 - 2012; e (c) aceleração média da produção de soja durante o período 1993-2012 a partir de dados absolutos. 

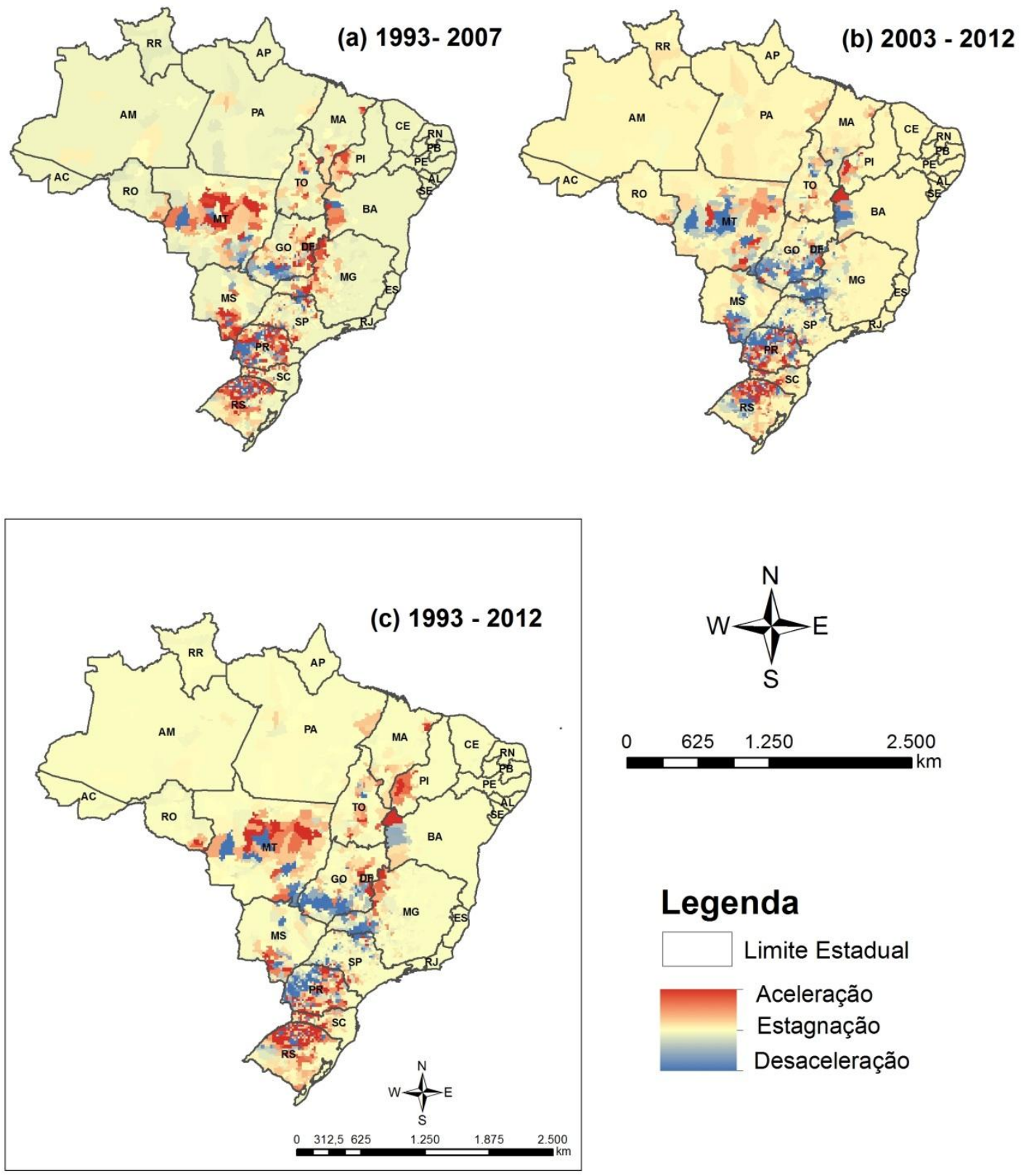

Figura 24. Mapa de aceleração de produção de soja durante o período de 1993 a 2012 a partir dos dados normalizados da produção. (a) 1993- 2007; (b) 2003-2012; e (c) aceleração média da produção de soja durante o período de 1993 -2012 a partir de dados normalizados. 


\subsubsection{Mapas de Aceleração da Produção de Milho (1993 - 2012)}

\section{Resultados com dados absolutos}

No período 1993-2007 a aceleração da produção de milho ocorreu em municípios do PR, MS, MT, GO, MG e oeste da BA (Figura 25). O período 2003-2013 indica maior destaque da aceleração do crescimento da produção nos municípios do estado do MT, MS, GO, oeste da BA, PI, sul do MA e no PA. Nesse período a desaceleração da produção de milho esteve presente nos municípios do PR, SP e porção sul e oeste de MG.

O mapa da aceleração média da produção de milho durante 1993-2012 indicou concentração da aceleração do crescimento da produção na região Centro - Oeste (MT, MS, GO), na divisa entre GO e MG, ao norte do PA e na região Nordeste, mais especificadamente nos municípios dos estados da BA, PI e MA (Figura 25).

\section{Resultados com dados normalizados}

O período 1993-2007 apresentou aceleração da produção nos municípios do RS, SC, MS, SP, MG, GO, MT, SE e PE (Figura 26). No período 2003-2012, a desaceleração do crescimento da produção se destacou em muitos municípios, principalmente nos de SC, PR, SP e MG.

O mapa da aceleração média da produção de milho no período 1993-2012 indicou aceleração nos municípios do RS, SC, PR, MS, MT, GO, na região de divisa entre MG e GO, e também no SE (Figura 26). O mapa também aponta destaque da desaceleração do crescimento em municípios de SC, PR, SP e sul de MG. 
(a) 1993- 2007

(b) $2003-2012$
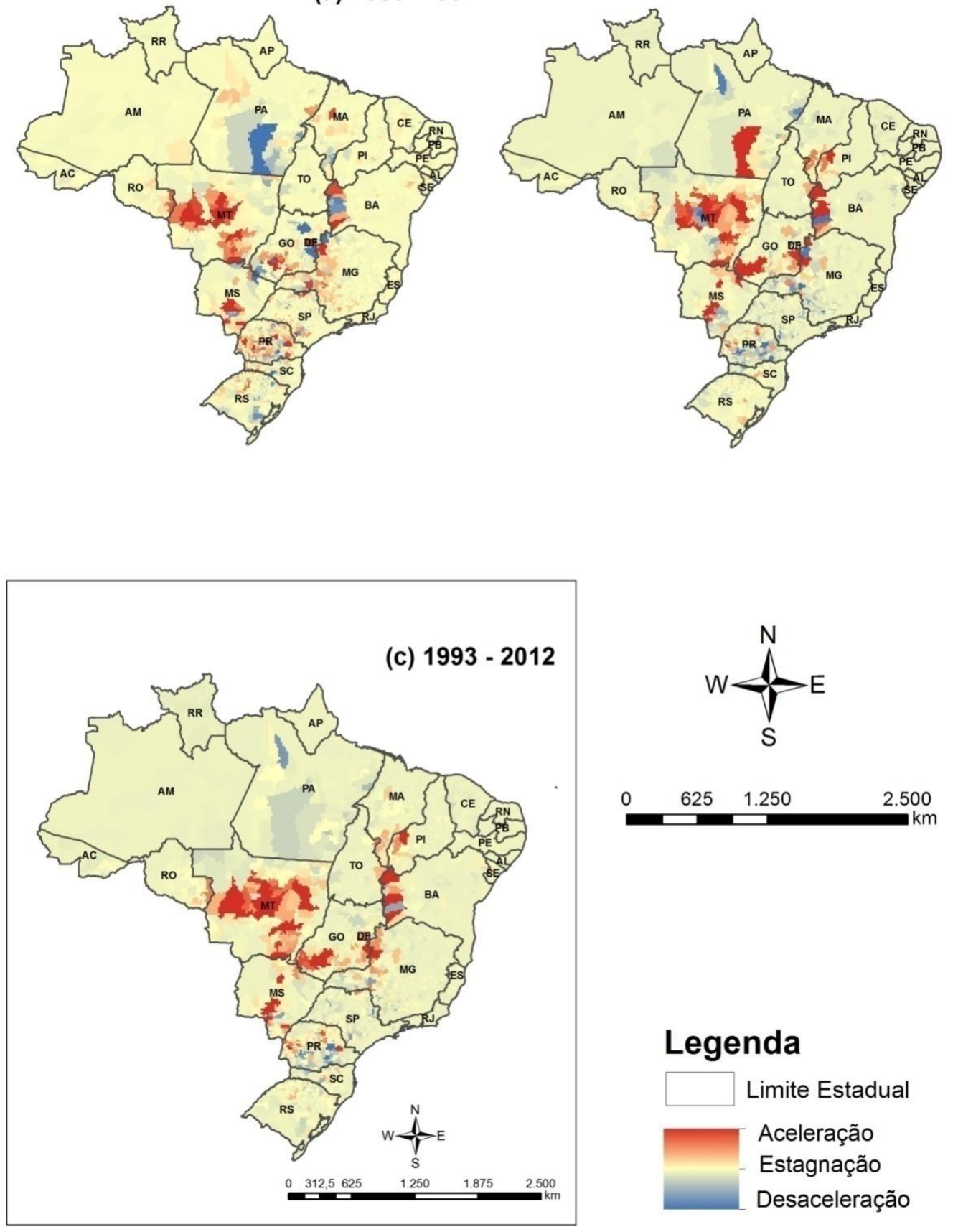

\section{Legenda}

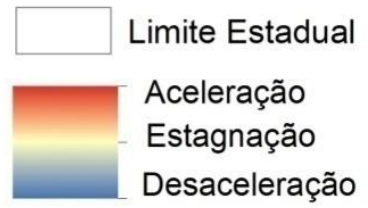

Figura 25. Mapas de aceleração da produção de milho a partir dos dados absolutos da produção: (a) 1993-2007; (b) 2003-2012; e (c) aceleração média da produção de milho durante o período 1993-2012 a partir de dados absolutos. 

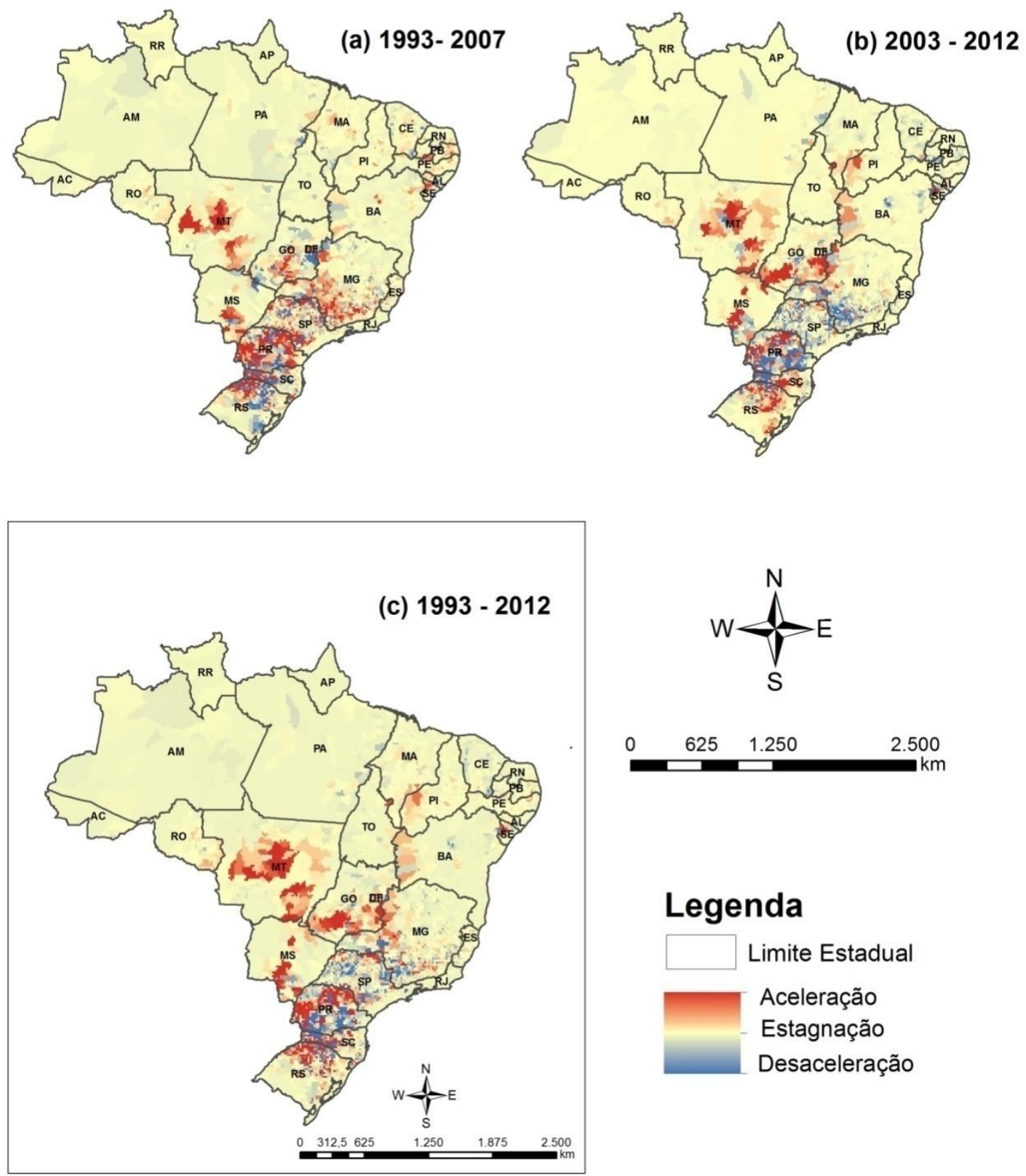

Figura 26. Mapa de aceleração da produção de milho a partir dos dados normalizados da produção. (a) 1993-2007; (b) 2003-2012; (c) aceleração média da produção de milho durante o período 1993-2012 a partir de dados normalizados. 


\subsection{Ponto Médio Espacial das Produções}

A produção bovina no período 1978-2012 indicou movimento para o noroeste do país. A produção de cana de açúcar durante o período 1990-2012 deslocou-se da região Nordeste para a porção sudoeste do país. Os resultados do ponto médio das produções de soja e a produção de milho de 1990-2012 sugerem que ambas as atividades se moveram ao longo do tempo da região Sul para a região Norte do país (Figura 27 e 28).
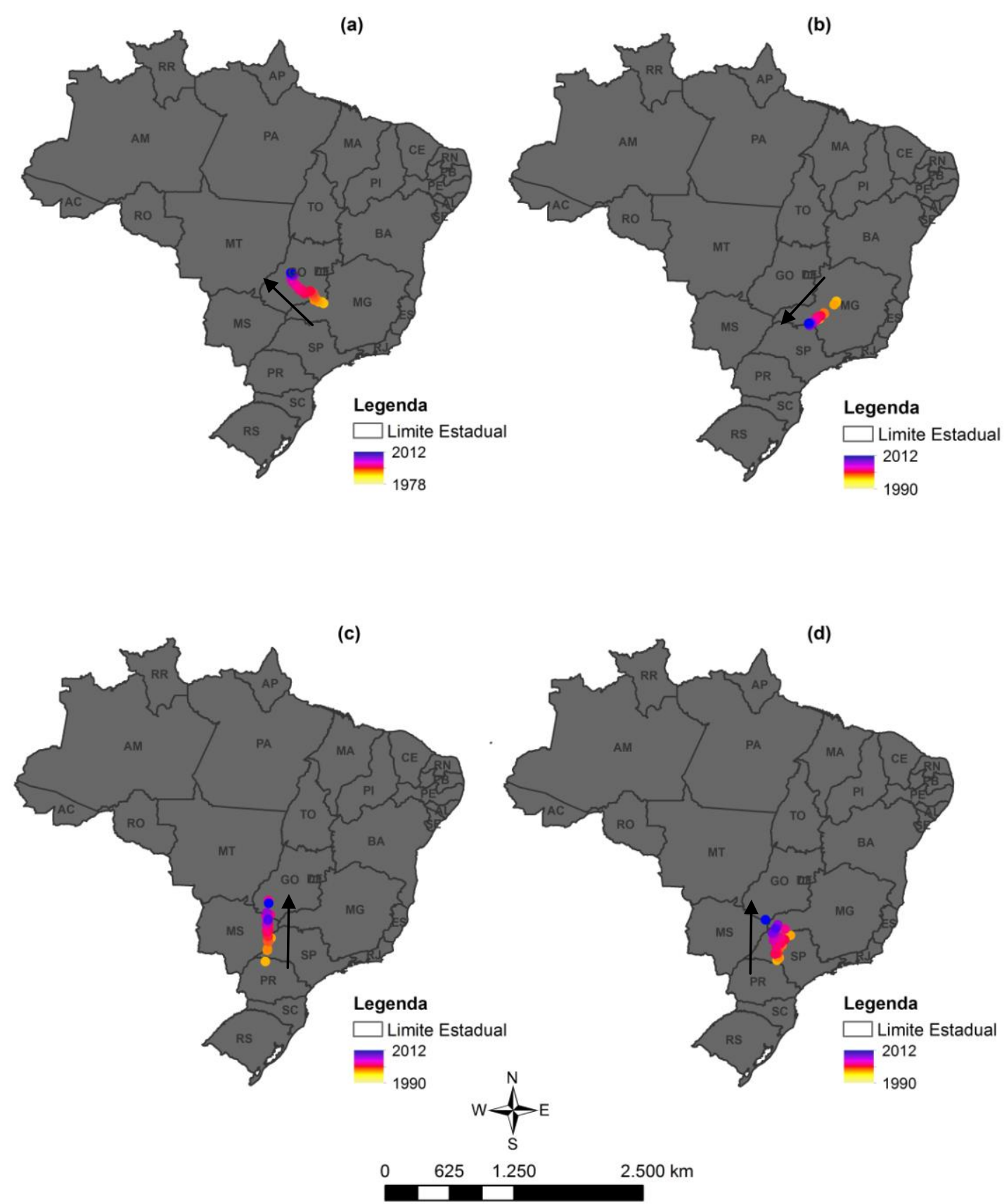
Figura 27. Mapas do ponto médio espacial das produções. (a) Ponto médio da produção bovina de 1978- 2012; (b) Ponto médio da produção de cana de açúcar de 1990-2012; (c) Ponto médio da produção de soja de 1990-2012; (d) Ponto médio da produção de milho de 1990-2012.

(a)

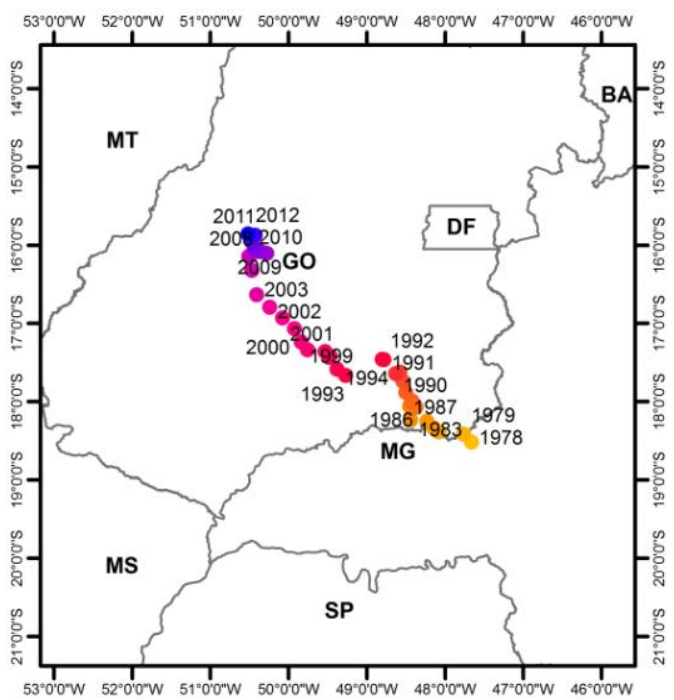

(c)

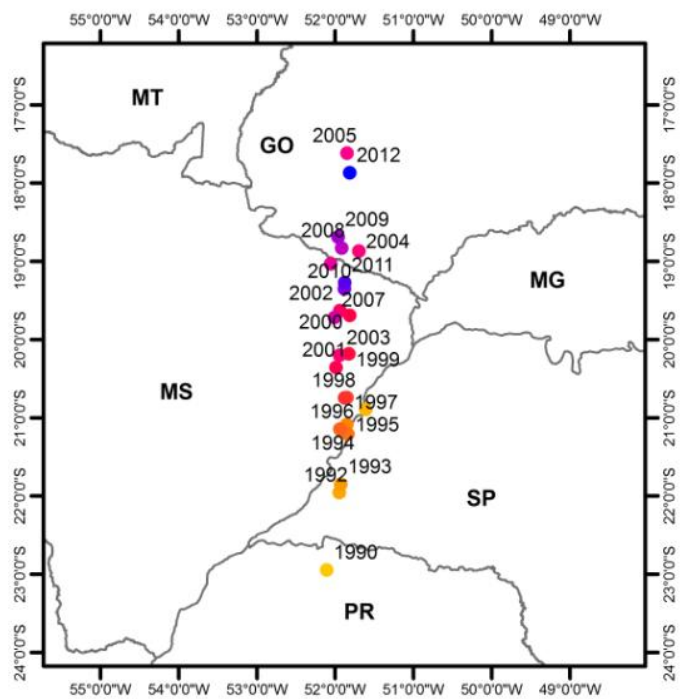

(b)

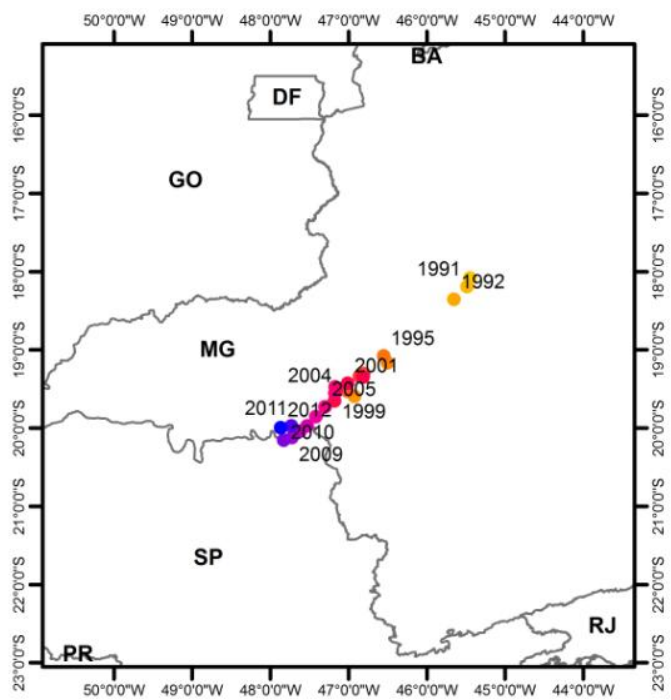

(d)

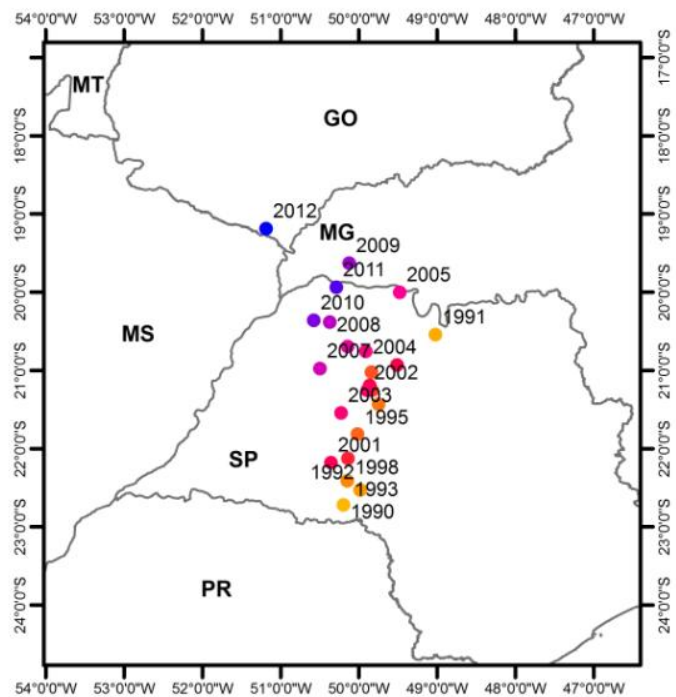

Figura 28. Detalhe do ponto médio espacial das produções. (a) Ponto médio da produção bovina de 1978- 2012; (b) Ponto médio da produção de cana de açúcar de 1990-2012; (c) Ponto médio da produção de soja de 1990-2012; (d) Ponto médio da produção de milho de 1990-2012. 


\subsection{Correlação Inversa das Produções}

5.5.1. Correlação inversa entre a produção bovina e a produção de cana de açúcar durante o período 1993- 2012

A partir do período 2002-2006 torna-se mais aparente a correlação inversa nos municípios dos estados de SP, PR, MG, MS e MT (Figura 30). Durante o período 20042012, as regiões com maior número de municípios com correlação inversa menor que 0,7 foram a Sudeste, Centro - Oeste e região Sul (Tabela 9).

Tabela 9. Número de municípios por região com forte correlação (menor que -0,7).

\begin{tabular}{|llllll|}
\hline Períodos & Norte & Nordeste & Centro-Oeste & Sudeste & Sul \\
\hline $2004-2008$ & 22 & 22 & 63 & 140 & 40 \\
\hline $2005-2009$ & 23 & 23 & 64 & 121 & 46 \\
\hline $2006-2010$ & 19 & 19 & 53 & 94 & 40 \\
\hline $2007-2011$ & 28 & 25 & 62 & 94 & 31 \\
\hline $2008-2012$ & 33 & 35 & 60 & 92 & 45 \\
\hline
\end{tabular}

\subsubsection{Correlação inversa destacando o aumento da produção bovina e a diminuição da produção de cana de açúcar (2003-2012)}

Durante o período 2003- 2009 os municípios que apresentaram aumento da produção bovina e redução da produção de cana de açúcar ao longo do tempo estavam presentes nos estados de RO, PA, MA, CE, PI, porção noroeste e sul do MT, MG, BA, RS, PR e MS (Figura 32).

O período 2006-2010 apresentou tal resultado nos municípios próximos às divisas da região Centro-Oeste com a região Norte e os municípios no norte de $\mathrm{MG}$, sul da BA, ES, RJ, CE, MA, SE, GO, SC, PR, RS. O período 2007-2011 realçou os municípios dos estados de MT, RO, PA, AM, TO, MA, norte do GO, norte de MG, sul da BA, ES e PR. Entre 2008-2012 notou-se o aumento da produção bovina e diminuição da cana de açúcar nos municípios de RO, no sul da AM, PA, TO, norte do GO, norte de MG, BA, ES, CE, SC e RS. 


\subsubsection{Correlação inversa destacando a diminuição da produção bovina e aumento da produção de cana de açúcar (2003-2012)}

De maneira geral, todos os períodos apresentaram resultados constantes com aumento da produção da cana de açúcar e a redução da produção bovina ao longo do tempo em municípios de SP, MS, sul do GO, MG, norte do PR (Figura 33). O período 2003-2009 ressaltou esses resultados.

No período 2004-2009 os municípios de TO exibiram forte correlação inversa indicando o aumento da cana de açúcar e a redução da produção bovina. O período 2005-2012 destacou municípios em RO, AC, norte da BA, PE e no norte do ES e sul da BA.

Obteve-se um número maior de municípios com aumento da produção de cana de açúcar e diminuição da produção bovina ao longo do tempo do que de municípios com aumento da produção bovina e redução da produção de cana de açúcar (Tabela 10 e 11).

Tabela 10. Número de municípios onde a produção bovina diminuiu e a cana de açúcar aumentou de acordo com o grau de correlação.

\begin{tabular}{|lll|}
\hline Períodos & $-0,4$ até $-0,7$ & $-0,7$ até -1 \\
\hline $2003-2007$ & 92 & 156 \\
\hline $2004-2008$ & 124 & 165 \\
\hline $2005-2009$ & 129 & 144 \\
\hline $2006-2010$ & 107 & 114 \\
\hline $2007-2011$ & 101 & 96 \\
\hline $2008-2012$ & 79 & 94 \\
\hline
\end{tabular}

Tabela 11. Número de municípios onde a produção bovina aumentou e a cana de açúcar diminuiu de acordo com o grau de correlação.

\begin{tabular}{|lll|}
\hline Períodos & $-0,4$ até $-0,7$ & $-0,7$ até -1 \\
\hline $2003-2007$ & 38 & 51 \\
\hline $2004-2008$ & 48 & 51 \\
\hline
\end{tabular}




\begin{tabular}{|lll|}
\hline $2005-2009$ & 28 & 60 \\
\hline $2006-2010$ & 36 & 48 \\
\hline $2007-2011$ & 56 & 53 \\
\hline $2008-2012$ & 49 & 57 \\
\hline
\end{tabular}



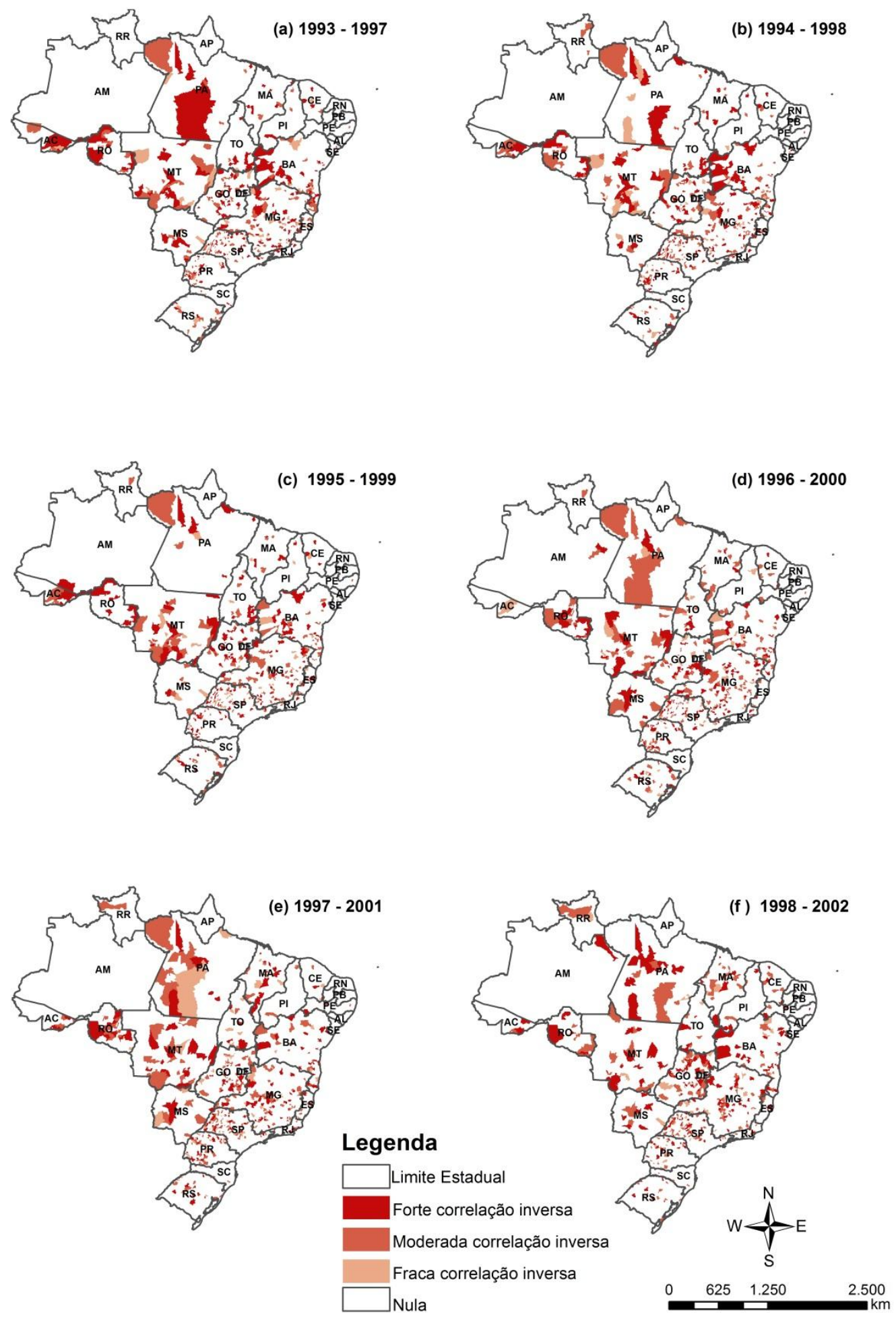

Figura 29. Correlação inversa entre a produção bovina e a produção de cana de açúcar. (a) 1993-1997; (b) 1994-1998; (c) 1995-1999; (d) 1996-2000; (e) 1997-2001; (f) 1998- 
2002.
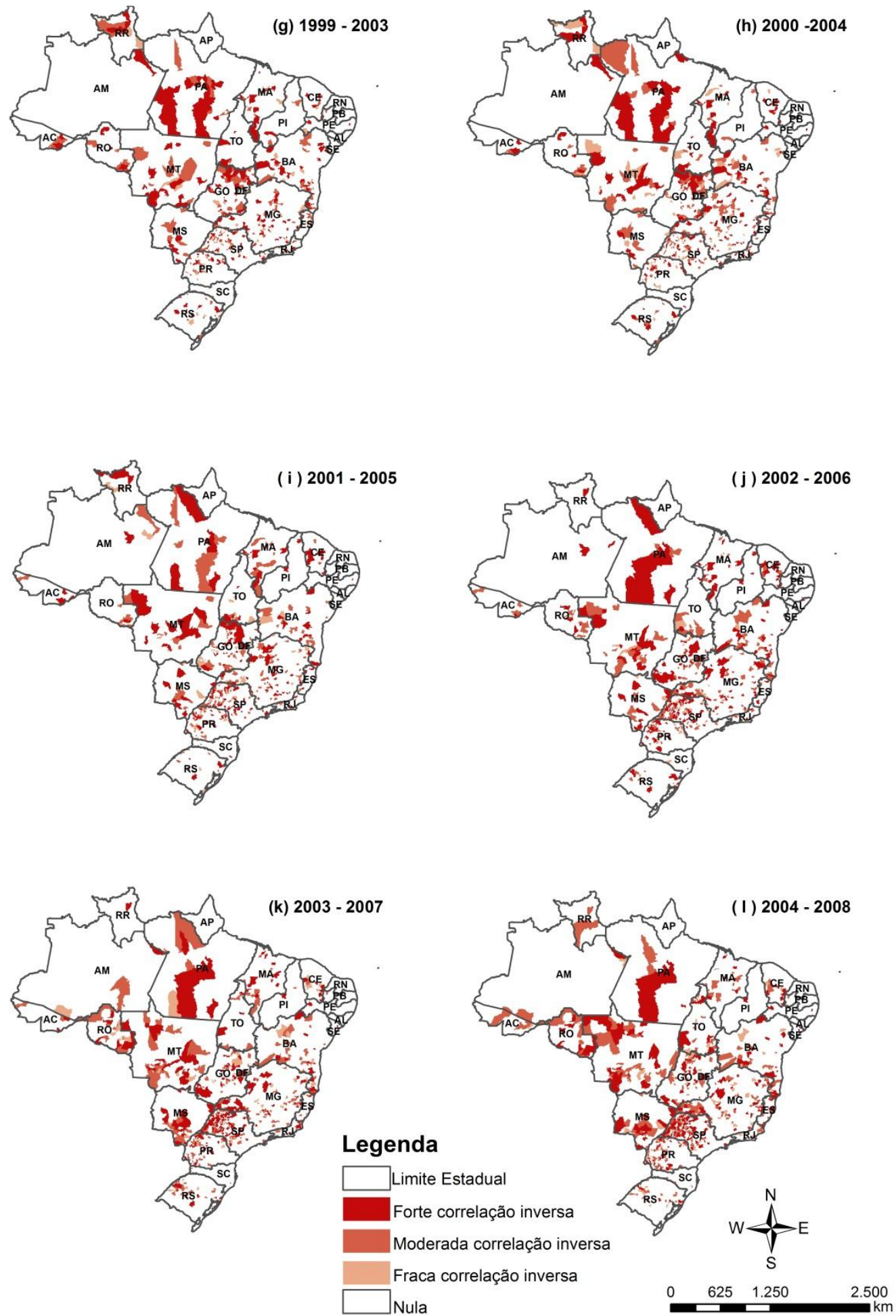

Figura 30. Correlação inversa entre a produção bovina e a produção de cana de açúcar. (g) 1999-2003; (h) 2000-2004; (i) 2001-2005; (j) 2002-2006; (k) 2003-2007; (l) 20042008 . 

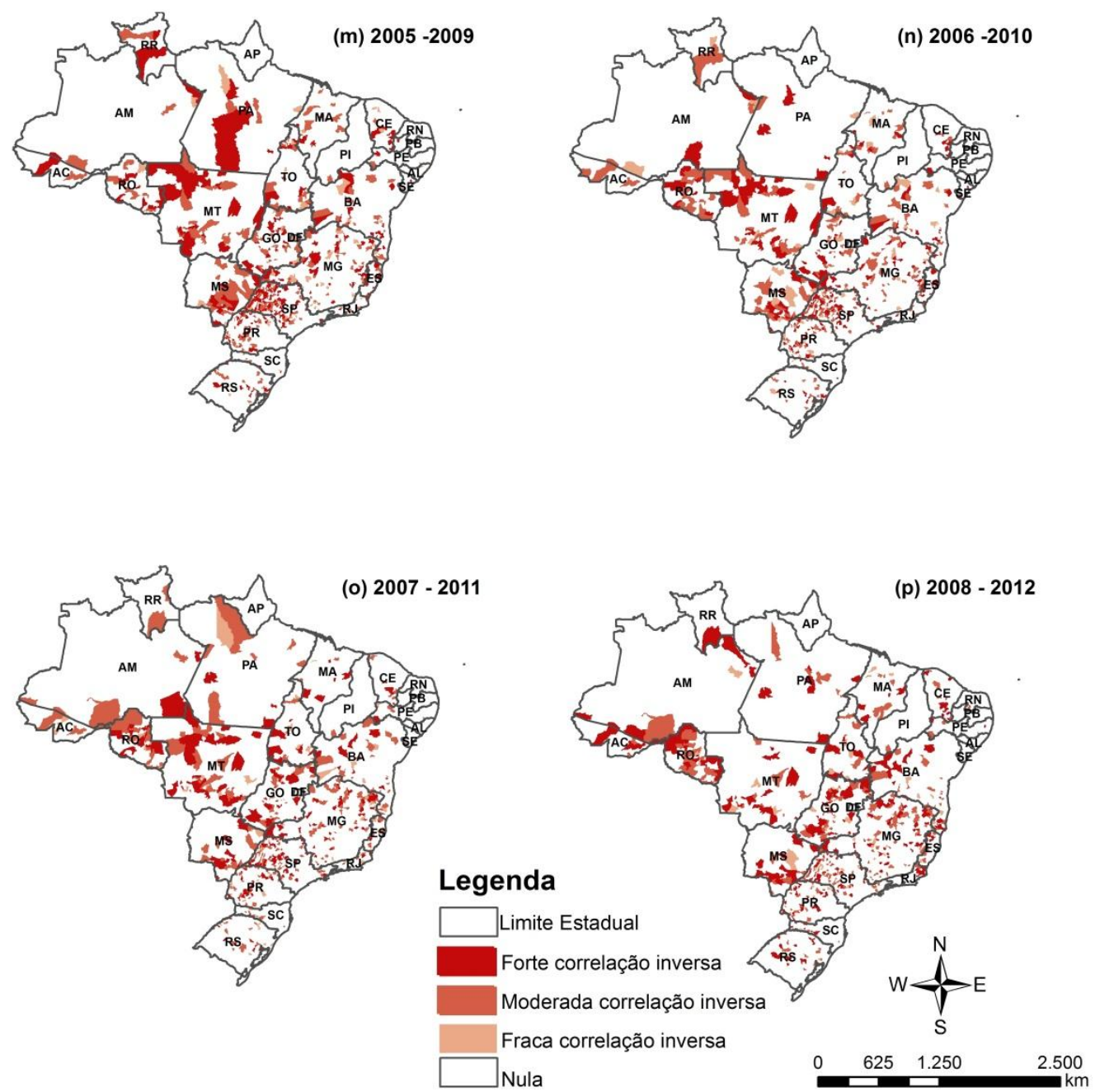

Figura 31. Correlação inversa entre a produção bovina e a produção de cana de açúcar. (m) 2005-2009; (n) 2006-2010; (o) 2007-2011; (p) 2008-2012. 

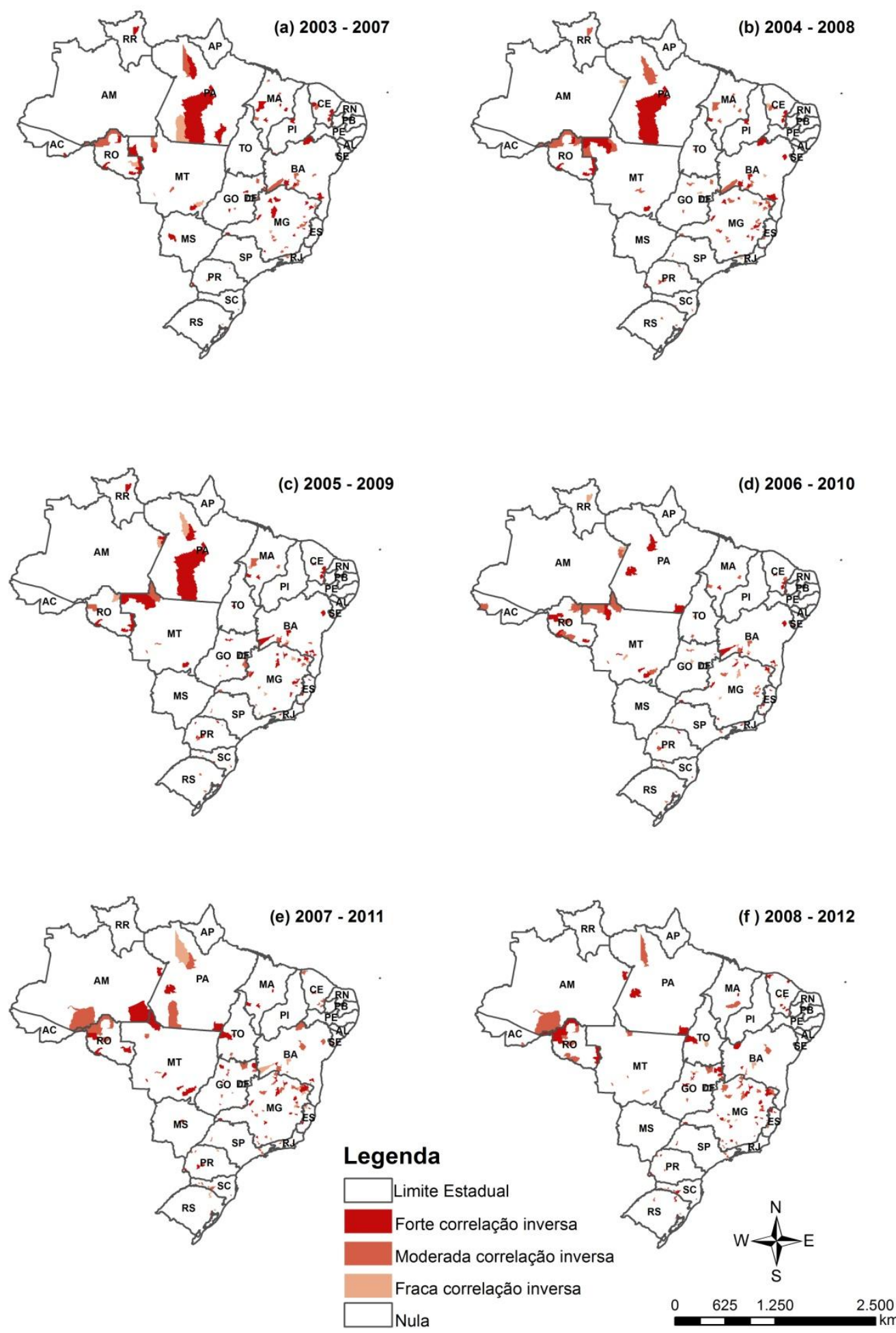

Figura 32. Correlação inversa destacando o aumento da produção bovina e a diminuição da produção de cana de açúcar. (a) 2003-2007; (b) 2004-2008; (c) 20052009; (d) 2006-2010; (e) 2007-2011; (f) 2008-2012. 

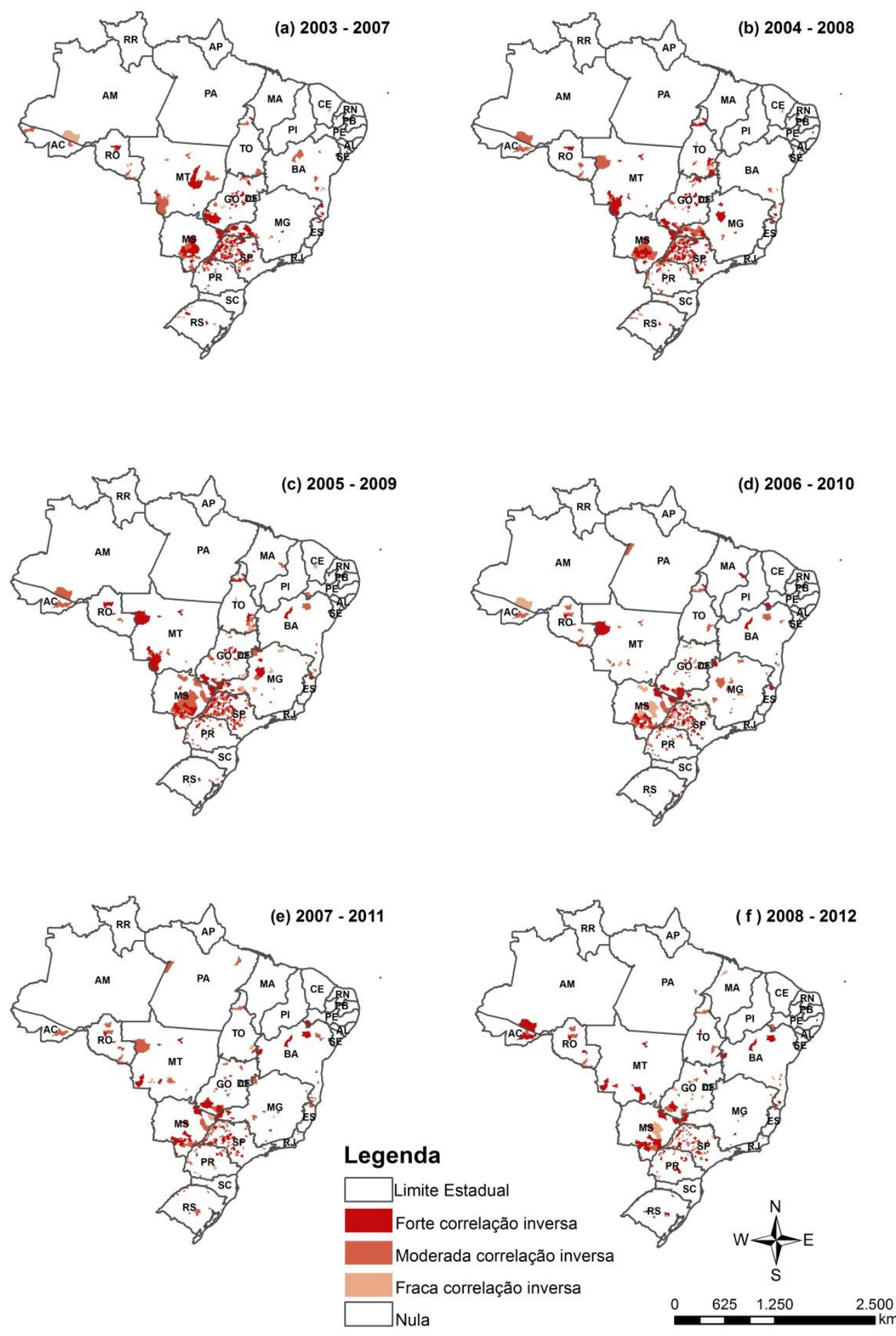

Figura 33. Correlação inversa destacando o aumento da produção de cana de açúcar e a diminuição da produção bovina. (a) 2003-2007; (b) 2004-2008; (c) 2005-2009; (d) 2006-2010; (e) 2007-2011; (f) 2008-2012. 


\subsubsection{Correlação inversa entre a produção bovina e a produção de soja durante o período de 1993- 2012}

O período 1993 -1997 evidenciou grande quantidade de municípios com média e forte correlação inversa nas regiões Centro-Oeste, Sudeste, Sul e também nos municípios dos estados do PI, MA, TO e BA (Figura 34). O período 1994-2000 também expressou esse resultado, porém com menor intensidade.

O período 1999-2003, em especial, mostrou municípios com forte correlação inversa em muitos estados brasileiros como AC, RR, RO, PA, TO, MA, PI, CE, PE, PA, BA, GO, MT, MS, MG, ES, RJ, SP, PR, e RS (Figura 35).

Ao contrário do período de 1999-2003, entre 2000-2006 houve menor quantidade de municípios com forte correlação inversa. Os municípios que se destacaram são os da região Centro-Oeste, Sul e Sudeste.

Durante 2003-2009 destacou-se a concentração de municípios do estado do MS, PR, com forte e média correlação inversa (Figura 35 e 36). No período 2007-2012 foi apontada média e forte correlação inversa nos estados do TO e na porção leste do PA. As regiões Centro-Oeste, Sudeste e Sul seguiram exibindo forte e média correlação inversa em seus municípios.

Entre 2003-2012 as regiões que apresentaram maior quantidade de municípios com forte correlação inversa entre a produção bovina e a produção de soja foram as regiões Sul, Centro-Oeste e Sudeste (Tabela 12).

Tabela 12. Número de municípios por região com forte correlação (menor que -0,7).

\begin{tabular}{|llllll|}
\hline Períodos & Norte & Nordeste & Centro-Oeste & Sudeste & Sul \\
\hline $2004-2008$ & 17 & 3 & 40 & 32 & 56 \\
\hline $2005-2009$ & 19 & 2 & 40 & 35 & 43 \\
\hline $2006-2010$ & 22 & 3 & 35 & 22 & 39 \\
\hline $2007-2011$ & 17 & 3 & 35 & 25 & 31 \\
\hline $2008-2012$ & 16 & 1 & 37 & 34 & 34 \\
\hline
\end{tabular}




\subsubsection{Correlação inversa destacando o aumento da produção bovina e redução da produção de soja (2003- 2012)}

Em todos os períodos analisados foram poucos os municípios que apresentaram o aumento da produção bovina e a redução da produção de soja ao longo do tempo (Figura 37). Uma pequena quantidade de municípios esteve destacada em MG, GO, MT, MS, MG, TO, MA e em RO.

\subsubsection{Correlação inversa destacando a diminuição da produção bovina e aumento da produção de soja (2003-2012)}

Durante 2003-2012, os municípios que apresentaram forte e média correlação inversa e indicaram o aumento da produção de soja e redução da produção bovina estavam situados nos estados do MT, MS, GO, MG, SP, PR, RS, SC e também no estado do TO, na porção leste do PA e no MA (Figura 38). Em menor quantidade, foram apontados municípios no AC, RO e BA.

Os resultados apresentaram uma quantidade maior de municípios que apontaram aumento da produção de soja e redução da produção bovina do que municípios que tiveram diminuição da produção de soja e aumento da produção bovina ao longo do período analisado (Tabela 13 e 14).

Tabela 13. Número de municípios onde a produção bovina diminuiu e a soja aumentou de acordo com o grau de correlação.

\begin{tabular}{|lll|}
\hline Períodos & $-0,4$ até $-0,7$ & $-0,7$ até -1 \\
\hline $2003-2007$ & 62 & 38 \\
\hline $2004-2008$ & 55 & 60 \\
\hline $2005-2009$ & 74 & 59 \\
\hline $2006-2010$ & 67 & 49 \\
\hline $2007-2011$ & 61 & 42 \\
\hline $2008-2012$ & 61 & 51 \\
\hline
\end{tabular}

Tabela 14. Número de municípios onde a produção bovina aumentou e a produção de soja diminuiu de acordo com o grau de correlação. 


\begin{tabular}{|lll|}
\hline Períodos & $-0,4$ até $-0,7$ & $-0,7$ até -1 \\
\hline $2003-2007$ & 27 & 25 \\
\hline $2004-2008$ & 37 & 28 \\
\hline $2005-2009$ & 40 & 25 \\
\hline $2006-2010$ & 31 & 21 \\
\hline $2007-2011$ & 30 & 21 \\
\hline $2008-2012$ & 29 & 23 \\
\hline
\end{tabular}



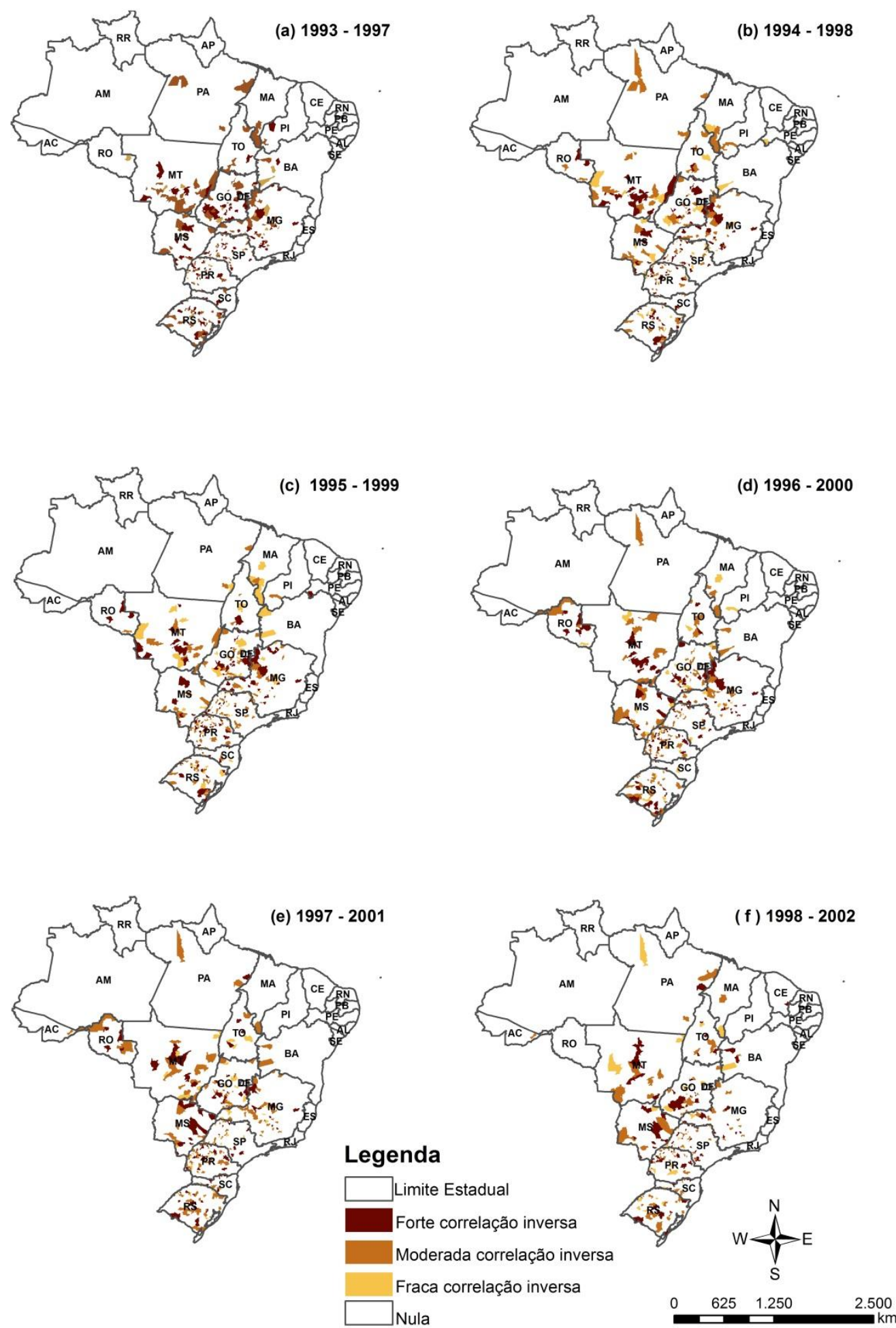

Figura 34. Correlação inversa entre a produção bovina e a produção de soja. (a) 19931997; (b) 1994-1998; (c) 1995-1999; (d) 1996-2000; (e) 1997-2001; (f) 1998-2002. 

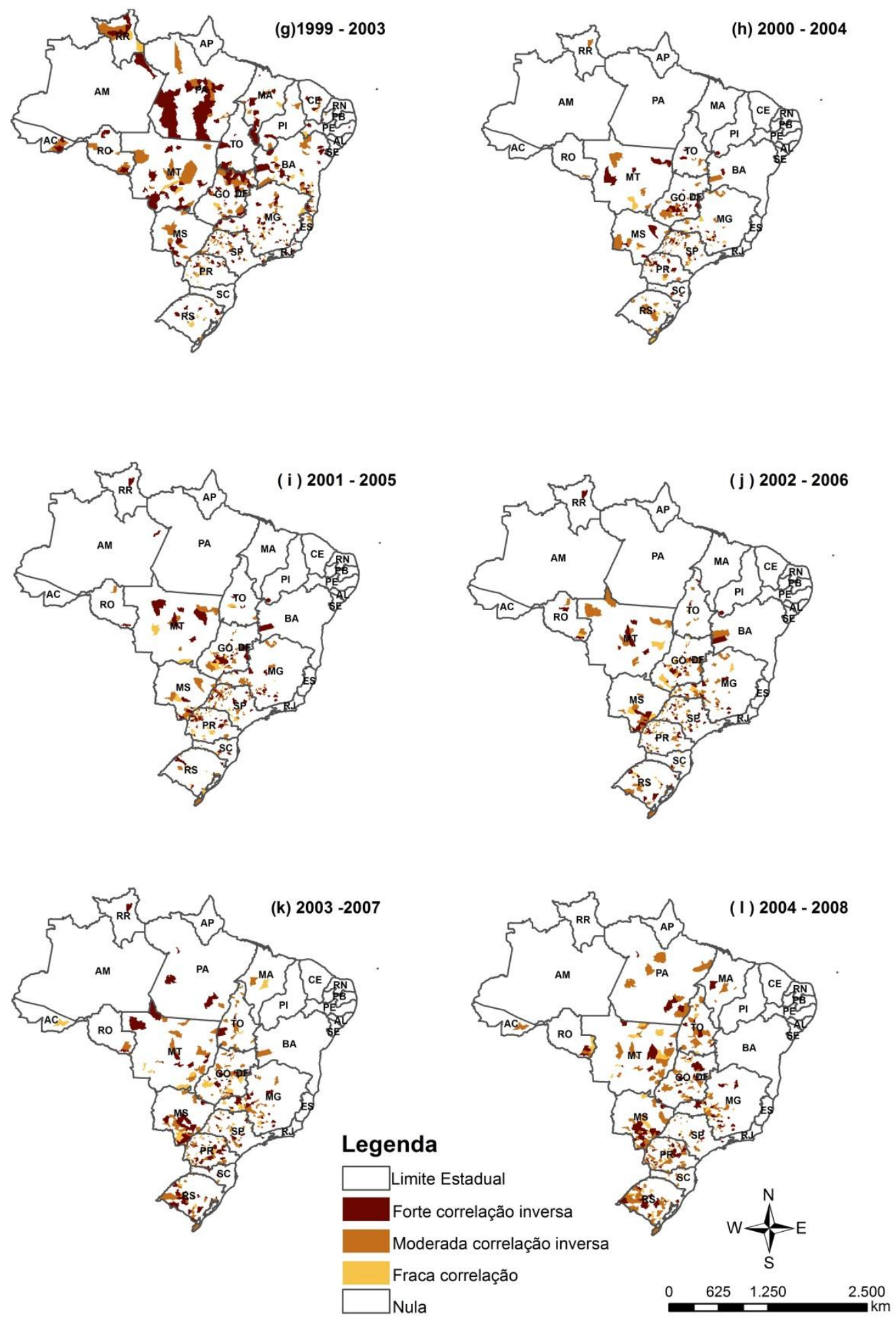

Figura 35. Correlação inversa entre a produção bovina e produção de soja. (g) 19992003; (h) 2000 -2004; (i) 2001-2005; (j) 2002-2006; (k) 2003-2007; (l) 2004-2008. 

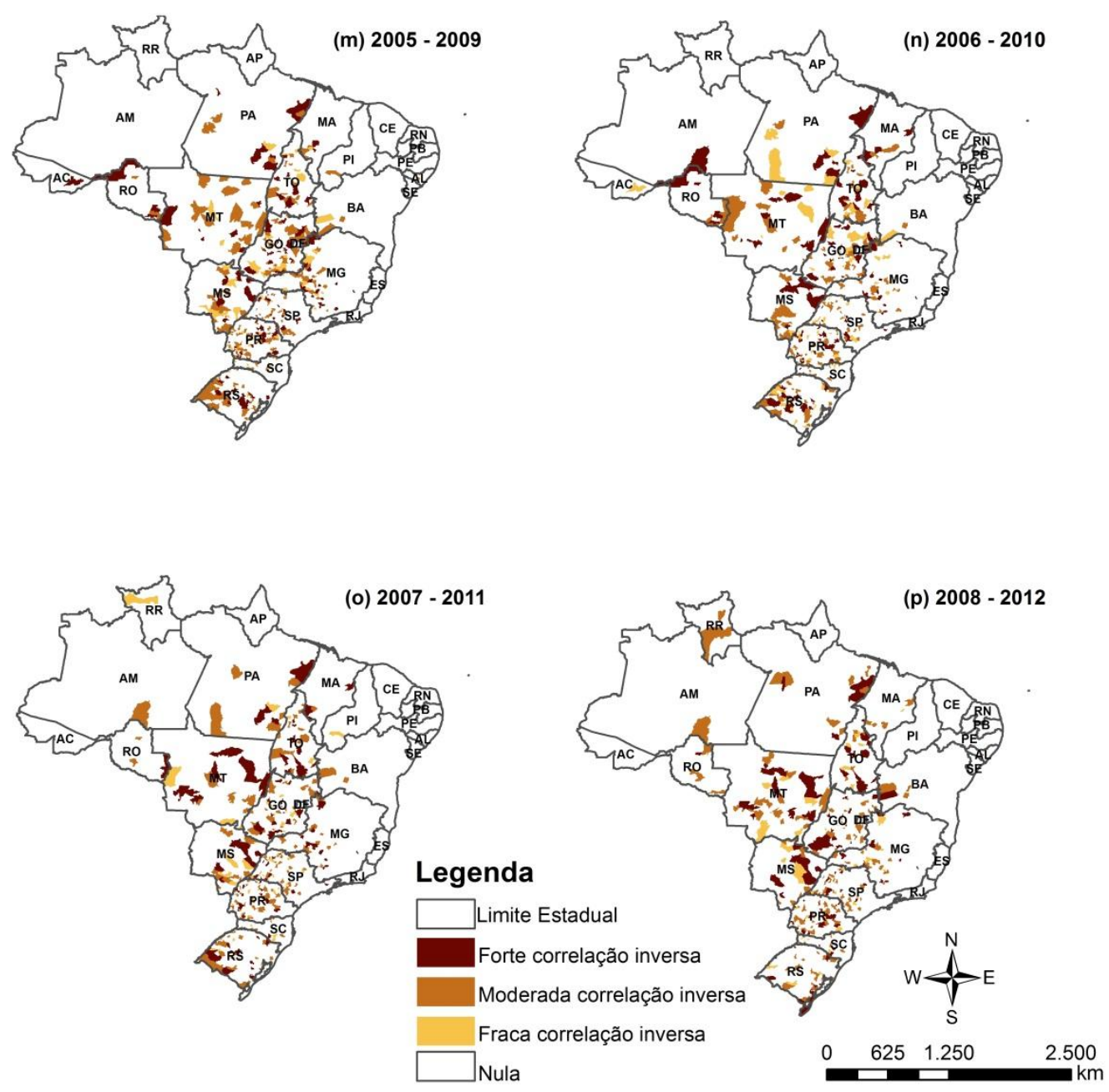

Figura 36. Correlação inversa entre a produção bovina e a produção de soja. (m) 2005 2009; (n) 2006 -2010; (o) 2007-2011; (p) 2008-2012. 

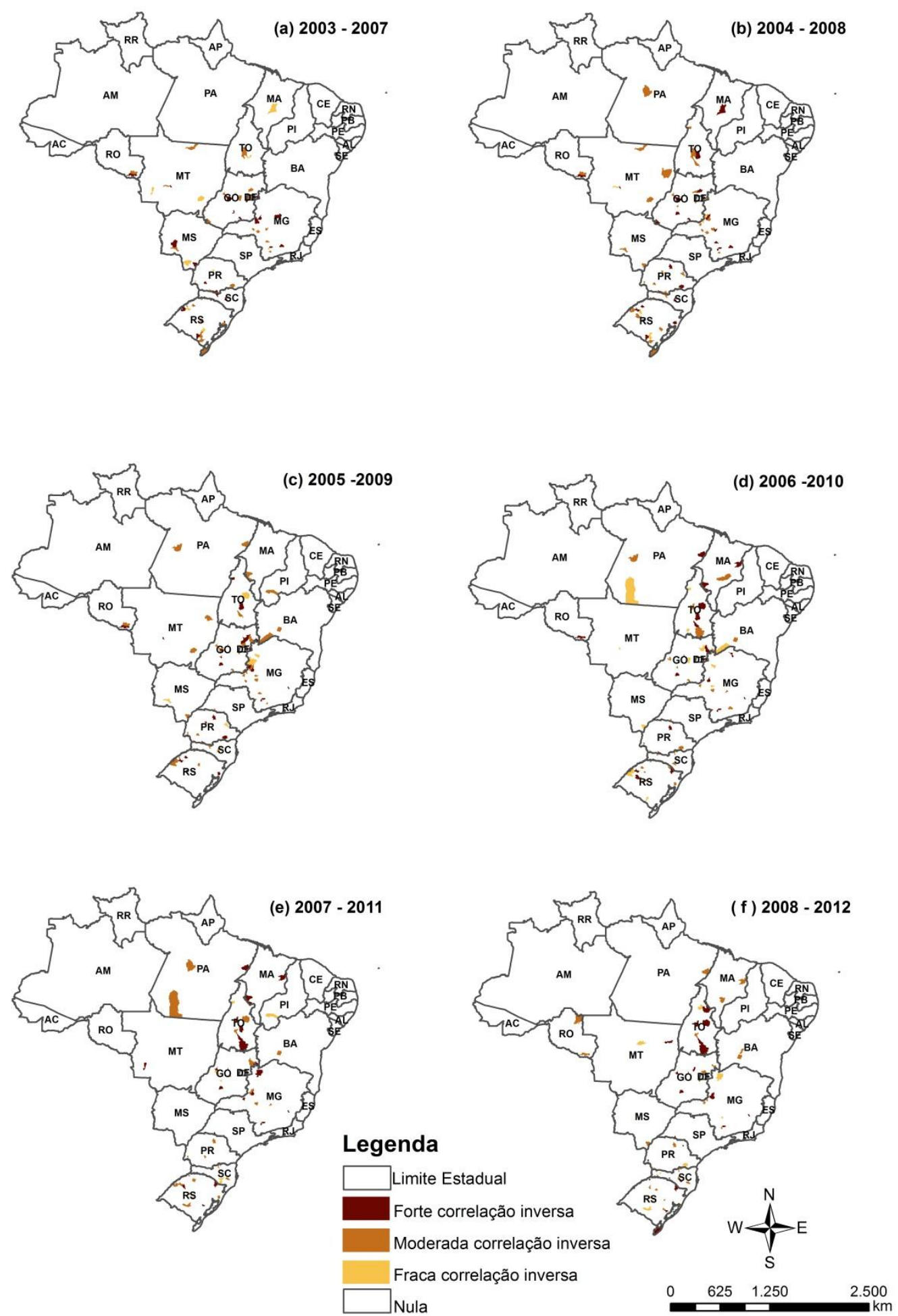

Figura 37. Correlação inversa destacando o aumento da produção bovina e a diminuição da produção de soja. (a) 2003-2007; (b) 2004-2008; (c) 2005-2009; (d) 2006 -2010; (e) 2007-2011; (f) 2008-2012. 

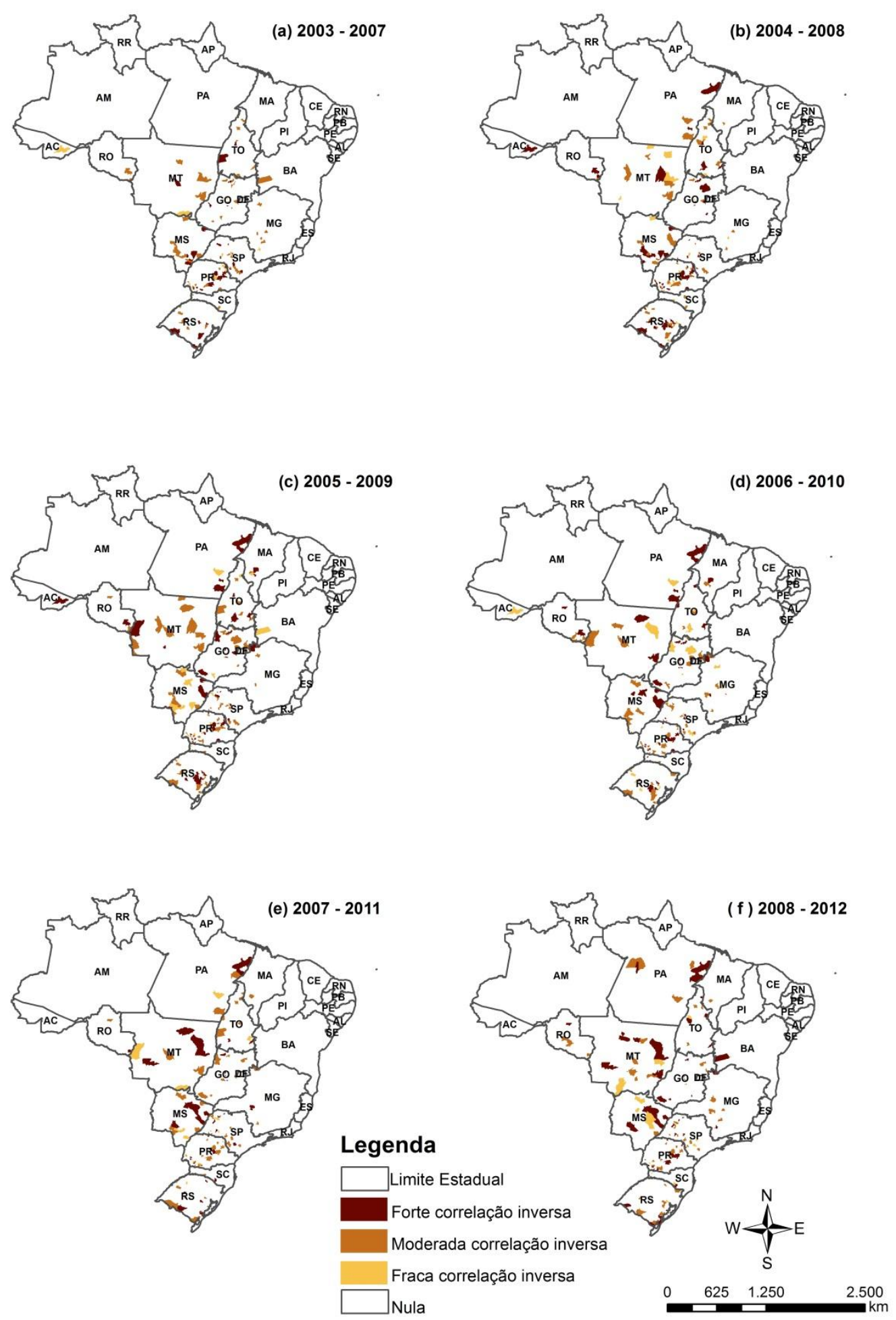

Figura 38. Correlação inversa destacando o aumento da produção de soja e a diminuição da produção bovina. (a) 2003-2007; (b) 2004-2008; (c) 2005-2009; (d) 2006 -2010; (e) 2007-2011; (f) 2008-2012. 


\section{DISCUSSÃ̃}

Os mapas das taxas de crescimento de produção de soja com dados absolutos (Figura 15) e normalizados (Figura 16) destacaram taxa de crescimento superior a 50\% nos municípios da região Sul, Centro-Oeste, na parte oeste do Nordeste (TO, BA, PI, MA) e em alguns municípios do Norte (RO, sul da AM e PA). O mesmo padrão pôde ser visto nos mapas das taxas de crescimento de milho (Figura 17 e 18). Os mapas de produção de soja em toneladas (Figura 7) destacaram os municípios com maior produção nos estados de MT, MS, MG, BA, MA, PI, RS e PR. As maiores produções de milho em toneladas (Figura 8) também estão indicadas nos mesmos estados e, também, em SP.

Os mapas de aceleração com os dados brutos de produção de milho e soja (Figura 23 e 25) apontaram aceleração nos municípios de GO, MG, MT, PI e oeste da BA. Os mapas de aceleração com dados normalizados (Figura 24 e 26) destacaram também a região Sul do país e, no caso do milho, no período 1993-2007, foram também destacados os municípios do sul de MG. Os mapas do ponto médio das produções de milho e soja (Figura 27 e 28) indicam direções similares, ambas caminham para a região Norte do país. As produções de milho e soja tiveram resultados parecidos em razão de estarem geralmente associadas dado ao tipo de manejo de sistema de rotação de terrenos que os agricultores utilizam, alternando milho e soja (BNDES, 2011).

Nos mapas das taxas de crescimento de produção bovina usando séries temporais absolutas (Figura 9) e normalizadas (Figura 10) do período 1978-1987 até o período 1993-2002, os municípios das regiões Sul e Centro-Oeste tiveram a maior participação, apresentando taxas de crescimento superiores a 50\%. No entanto, os mapas da taxa de crescimento dos períodos 1998-2007 e 2003-2012 de produção bovina passaram a dar mais ênfase aos municípios da Região Norte: AC, RO, sul da AM, PA, AP; na parte oeste do Nordeste, MA; e região Centro - Oeste, norte do MT. Tal resultado casa com os resultados dos mapas de produção bovina em toneladas (Figura 5), do período 1978-2002, os municípios com maior produção bovina estavam localizados no MS, GO e RS. A partir do período 1998- 2007 municípios no PA, RO e no norte do MT também passam a se destacar entre as maiores produções. 
Cabe enfatizar que, como a taxa de crescimento depende da quantidade do período inicial, regiões com baixa produção local tendem a ter indicadores superiores, pois qualquer aumento produtivo é captado por uma significativa variação percentual. É por este motivo que aparecem muitos municípios com taxa de crescimento superior a $50 \%$ para as produções de cana de açúcar, milho e bovina nas regiões mais ao Norte do país, o que, de fato, não representa que as atividades foram expressivas em todos os municípios indicados.

De qualquer forma, dois fatores foram importantes para o deslocamento da produção de grãos e de carnes para o Centro-Oeste e para o Meio-Norte, nas últimas décadas: agricultores com experiência na produção de grãos no Sul, região com terras escassas e caras e a disponibilidade de terras baratas nos Cerrado. (CONTINI, 2015). Esses dois fatores estiveram ligados a importantes políticas que tiveram papel central no processo de modernização: a disponibilidade de crédito subsidiado financeiro, principalmente para o financiamento de capital e a compra de insumos modernos; extensão rural; e o apoio da pesquisa agrícola (Sistema Nacional de Pesquisa Agropecuária, coordenada pela Empresa Brasileira de Pesquisa AgropecuáriaEmbrapa) (PEREIRA et al., 2012).

O Programa para o Desenvolvimento do Cerrado (POLOCENTRO) e o Programa de Cooperação Nipo-Brasileira para o Desenvolvimento do Cerrado (PROCEDER) favoreceram o processo de ocupação, principalmente por migrantes agricultores sulistas, nas regiões do cerrado e amazônica (VIEIRA JUNIOR et al., 2014). Adicionalmente, a ação pública da Política de Garantia de Preços Mínimos (PGPM) que atendeu especialmente os produtores de milho, soja, arroz e feijão, teve papel importante durante o período de instabilidade monetária brasileira na década de 80 (BACCARIN, 2008).

Segundo Capacle Correa e Ramos (2010), a ação do Estado foi essencial para o processo de expansão agrícola para a área de fronteira. A expansão não foi originada apenas por políticas setoriais agrícolas, mas, especialmente pela interiorização de grandes investimentos federais em infra-estrutura de transportes, na figura dos grandes eixos rodoviários. Projetos rodoviários inseridos no Programa de Integração Nacional PIN durante a década de 70, como a Belém-Brasília, a Cuiabá-Santarém, a Cuiabá-Porto 
Velho- Manaus, a Perimetral Norte e a Transamazônica ajudaram a estimular a imigração e a formação de atividades econômicas (PRATES e BACHA, 2011).

A criação de programas de financiamento e de investimento na segunda metade da década de 1990, principalmente com a criação do Programa Nacional de Fortalecimento da Agricultura Familiar (PRONAF) e do Programa de Modernização da Frota de Tratores Agrícolas e Implementos Associados e Colheitadeiras (MODERFROTA), foi importante para a renovação da frota de tratores e colheitadeiras na agricultura brasileira, com o aumento do volume de crédito nos últimos 15 anos (VIEIRA FILHO, 2014).

O período 1997-2008 e 2003-2012 indicou taxa de crescimento de produção de soja e milho, com dados absolutos (Figura 15 e 17) e normalizados (Figura 16 e 28), superior a $50 \%$ em municípios do MA, PI, BA e TO. Os mapas de aceleração da produção de soja e milho se destacaram aceleração nos municípios do oeste da BA, MA, TO e PI. Essas áreas foram incorporadas recentemente à atividade agrícola em decorrência das condições de clima e solo favoráveis a essa atividade, além do preço da terra e das possibilidades de expansão nos cerrados da região Norte e Nordeste (BORGHI et al., 2014).

O período 1988-1997 do mapa da taxa de crescimento de produção bovina tanto com valores brutos quanto normalizados (Figura 9 e 11, respectivamente) apresentou alta redução do crescimento nos estados da BA, SE, AL, PE, PB, RN e CE. O período 1993- 2002 dos mapas da taxa de crescimento de produção de cana de açúcar e de milho, com dados absolutos (Figura 13 e 17) e normalizados (Figura 14 e 18) indicou alta redução da taxa de crescimento na região nordestina. Ao longo da década de 90, a zona semi-árida da região foi assolada por secas de grandes proporções nos períodos de 1990 a 1993 e de 1998 a 1999. Em 1991, o fenômeno do El Niño surgiu de forma moderada na região estendendo-se até meados de 1993. Entretanto, entre 1997 e 1998, o episódio tomou proporções maiores, causando uma das maiores secas do século XX (MELO, 1999). Os efeitos econômicos e sociais dessas secas puderam ser avaliados por meio da queda no valor da produção agropecuária do Nordeste durante a época: $-11,7 \%$ em 1990; -9,2\% em 1992; -29,7\% em 1993; e -23,0\% em 1998 (SUDENE, 2000).

O período 2003-2012 da aceleração da produção bovina e a média da aceleração do crescimento da produção bovina com dados normalizados (Figura 20) destacou 
municípios da região Sudeste (MG, ES e RJ), região Sul (PR, SC e RS), região Nordeste (SE, AL e PE) e região Centro-Oeste (sul do GO). A maior parte do leite produzido no país é oriunda da região Sudeste, o que sugere a forte aceleração nessa região. Segundo a Pesquisa da Pecuária Municipal (IBGE, 2012), em 2012, o Sudeste do Brasil concentrou 35,9\% da produção de leite. Na sequiência, veio região Sul com participação de $33,2 \%$, seguido do Centro Oeste com 14,9\% e do Nordeste. O principal estado produtor de leite foi Minas Gerais, acompanhado do Rio Grande do Sul e Paraná.

De acordo com os mapas de produção em toneladas de cana de açúcar, os maiores produtores em 2003-2012 foram os municípios de SP, MS, MT, GO, MG, RJ, BA, AL, PE, PB e MA (Figura 6). O período 2003-2012 da taxa de crescimento de produção de cana de açúcar, com dados absolutos e normalizados (Figura 13 e 14), apontou para os mesmos municípios com alta taxa de crescimento de produção, principalmente os da região Centro-Sul e Centro-Oeste.

Os mapas da aceleração da produção de cana de açúcar (Figura 21 e 22) corroboram com os resultados da taxa de crescimento, no período 1993-2007 a aceleração da produção foi vista no Centro-Sul e também no MT, MA, leste do PA, RJ e municípios do RN, PB e PE. Em 2003-2012 destacou-se ainda mais a aceleração da produção de cana de açúcar na região Centro-Sul e a desaceleração em outros municípios fora da região, como na região Nordeste, nos estados do ES e RJ. A média da aceleração da produção de cana de açúcar (1993-2012) enfatizou a aceleração do crescimento da produção no Centro-Sul, mas indicou a desaceleração em municípios do Nordeste.

A presença da produção de cana de açúcar nos estados da região Centro-Sul é confirmada pelo mapa do ponto médio da produção (Figura 27 e 28) que mostrou, ao longo do período analisado, o deslocamento da atividade canavieira da região Nordeste para a região Centro-Sul do país. SP tornou-se a região de plantio de maior significado em razão do Programa PROÁLCOOL, após a segunda crise do petróleo. Na segunda metade dos anos 70 e 80 graças à boa infraestrutura, surgiu no estado uma densa rede de destilarias na maioria junto às fábricas de açúcar já existentes (KOHLHEPP, 2010). Outros estados, até então sem grande tradição na produção açucareira como PR, GO e MT, começaram a expandir suas culturas de cana (principalmente para produzir álcool), 
contribuindo para reduzir a participação no mercado interno dos produtores do Nordeste (SZMERECSÁNYI e MOREIRA, 1991).

Segundo Melo \& Pelin (1984) e Villanova (1995), a heterogeneidade regional da agroindústria canavieira não se refere somente no contexto dos problemas edafoclimáticos e topográficos que existem na região nordestina (em especial a qualidade do solo, as secas periódicas e a topografia relativamente acidentada que impede o uso mais intensivo de mecanização), mas, principalmente, porque nos estados do Centro-Sul, em especial, SP, a atividade apresenta tecnificação razoável em todas as fases da cultura, o que não acontece na maioria das unidades do Nordeste. O reforço em programas de I \& D, Investigação e Desenvolvimento (R \& D - Research and Development), são essenciais na região nordestina, onde a correta compreensão dos fatores locais mostra-se fundamental para o desenvolvimento do setor (MARTÍNEZ et al., 2013).

A introdução em 2003 do veículo flex-fuel no mercado automotivo, que possibilita o uso da mistura de gasolina com etanol em qualquer proporção, rendeu uma dinâmica positiva da produção canavieira, sendo e o estado de SP o representante mais importante desse setor. Em 2011, o estado paulista representou cerca de 54\% da produção nacional de cana de açúcar, 59\% de açúcar e 55\% de etanol (PROCANA, 2012; SHIKIDA,2014). Esse episódio colabora com a grande concentração de municípios com alta taxa de crescimento indicada, no período 2003- 2012 (Figura 13 e 14), no estado de SP e nos municípios dos estados do Centro-Sul. A aceleração em 2003-2012 (Figura 21 e 22) concorda com essa dinâmica e destacou a região com forte aceleração.

O período 2003-2012 indicou redução da taxa de crescimento de produção bovina, nos mapas com dados absolutos e normalizados (Figura 9 e 11),em municípios do MS, SP, oeste de SP, sul do GO, sul do MT e norte do PR. Nesse mesmo período, a produção bovina sofreu forte desaceleração, tanto nos mapas com dados absolutos e quanto normalizados (Figura 19 e 20), nos municípios do MS, SP, PR, sul do GO e MT.

A produção de milho no período 2003 - 2012 nos mapas da taxa de crescimento com dados absolutos e normalizados (Figura 17 e 18) sofreu alta redução e redução do crescimento, e indicou forte desaceleração da produção no mapa da aceleração do crescimento normalizado (Figura 26) nos municípios de SP, sul de MG e PR. 
Comportamento semelhante foi observado com a soja, que, no mesmo período apresentou alta redução e baixa redução da taxa de crescimento de produção, nos mapas com dados absolutos e normalizados (Figura 15 e 16), em municípios de SP, PR, MG, sul do GO e MS. A produção de soja em 2003 -2012 (Figura 23 e 24) se desacelerou nos municípios do PR, sul do GO e sul do MT.

Identifica-se correlação inversa entre produção bovina e cana de açúcar nas regiões Sudeste, Centro- Oeste e Sul, principalmente no período 2002-2010 (Figura 29,30 e 31). Durante 2003-2010 (Figura 33), a maioria dos municípios identificados com redução da produção bovina e aumento da produção de cana de açúcar estavam em SP, MS, MT, MG e GO.

Segundo Lourenzani e Caldas et al. (2014) entre 2003 e 2012, o oeste paulista representou metade da expansão de cana de açúcar do estado de SP, a incorporação das áreas cultiváveis nessa região se deu, predominantemente, pela cultura de cana de açúcar em substituição das áreas de pastagens e de áreas de cultivo de milho, feijão, algodão e soja. Deve-se esse fato principalmente pela entrada de carros flex-fuel no mercado brasileiro nesse mesmo período (RUDORFF et al., 2010). A dinâmica da produção das culturas agrícolas e da pecuária vai de encontro com as evidências de que grande parte do aumento da produção de cana no Centro-Sul foi alcançado através do aumento da produtividade de cana pela conversão de pastagens (HARVEY e PILGRIM, 2011).

Castro et al. (2010) aponta que a ampliação da cana de açúcar para os estados do Goiás e Mato Grosso do Sul foi feita pela substituição maciça de culturas anuais como a soja. De acordo com o autor, o que parece estar havendo é um grande rearranjo de usos dos solos no Centro-Sul do cerrado em razão da demanda expansiva e acelerado do setor sucroalcooleiro.

O período 2007-2012 (Figura 33) apresentou um menor número de municípios com correlação inversa entre produção bovina e de cana de açúcar, indicando a redução da produção bovina e o aumento da cana de açúcar no Centro-Sul, principalmente em SP. O comportamento pode ser explicado pela falta de chuvas regulares nas principais regiões produtoras entre o período de 2010 e 2012 e pelos efeitos da crise econômica internacional que se iniciou em 2008 sob o setor, restringindo os investimentos e a 
oferta de crédito, bem como retraindo o processo de implantação de novas usinas e expansão dos canaviais (IBGE, 2011).

Os municípios que apresentaram correlação inversa entre a produção bovina e a produção de soja estavam em sua maioria nas regiões do Centro- Oeste, Sudeste e Sul do país (Figura 34, 35 e 36). No período 2003-2012 (Figura 38), a região Sul foi a que apresentou maior quantidade de municípios com diminuição da produção bovina e aumento da produção de soja ao longo do tempo, seguido do Centro-Oeste e Sudeste. Destacaram-se os municípios na parte leste do PA, MA, RO, sul da AM e AC. O período de 2001 a 2004 foi caracterizado com alta de preços no mercado internacional resultando em grande dinamismo para a agricultura brasileira (BRANDÃO et al., 2005). Consequentemente, a soja tornou-se mais rentável, incentivando os produtores de gado a vender suas terras com lucro e abrir pastagem e em outros lugares (NEPSTAD et al., 2006).

Foi identificada uma quantidade relativamente menor de municípios com redução da produção de soja e aumento da produção bovina entre 2003 e 2012 (Figura 37), se comparado com os que tiveram aumento da produção de soja e diminuição da produção bovina no mesmo período (Figura 38). No período 2003 a 2010 estes municípios estavam localizados em sua maioria no TO, MA, PI, norte do GO, MG, RO, PA e região Sul. Entretanto, no período 2007- 2012 ressaltaram os municípios de TO, MA, PA, RO, GO e MG. Os municípios com redução da produção de cana de açúcar e aumento da produção bovina (Figura 32) tiveram destaque principalmente na porção norte do MT, PA, RO, MA, BA, CE, MG e ES.

Esses resultados conferem com os resultados dos mapas da taxa de crescimento de produção bovina (Figura 9 e 11) que apresentou, no período 1998-2007 e 2003-2012, alta taxa de crescimento de produção nos municípios que fazem parte da área da Amazônia Legal, especialmente, na porção norte do MT, oeste de RO, PA, sul da AM, AP, RR e MA. A maioria dos municípios identificados com aceleração do crescimento da produção bovina, no período 1998-2012, estava também na região da Amazônia Legal, nos municípios da porção norte do MT, RO, sul da AM, PA e MA.

De acordo com Bowman et al. (2012), alimentado pela demanda por carne no Brasil e no mercado mundial, o número de cabeças de gado cresceu de 147 milhões em 1990 para 200 milhões em 2007. Verificou-se uma expansão de 83\% na região 
amazônica. O mapa da produção bovina (Figura 5) apontou no período 1998-2012 uma maior quantidade de municípios em RO, sul da AM, AC, PA, MA e norte do MT com produção superior a 1,5 milhões de cabeças de gado.

Vale ressaltar que, nos mapas das médias da aceleração da produção bovina de 1978 a 2012 (Figura 19 e 20), a desaceleração da produção por toda parte leste do Centro- Oeste e parte leste da região Norte (ou oeste da região Nordeste) foi observada. Os mapas da média da taxa de crescimento de produção de soja (Figura 15 e 16) apresentaram nessas mesmas áreas municípios com taxa de crescimento superior a 50\% e os mapas da média da aceleração da produção de soja e milho (Figura 23, 24 e 25,26, respectivamente) apresentaram aceleração na porção oeste do Nordeste. Diante dessas ocorrências e somando-se o fato de que os mapas de correlação inversa indicaram o aumento das produções de cana de açúcar e soja e a redução do rebanho bovino nas regiões Centro-Sul, Centro-Oeste e na porção oeste do Nordeste, é possível compreender o direcionamento progressivo da produção bovina para a porção noroeste do país (Figura 27 e 28). Esse cenário reflete o forte impacto do processo de ocupação do Centro -Oeste e do oeste da região Nordeste sobre o crescimento de fronteiras comerciais na região Norte (SICSÚ e LIMA, 2000).

A partir destes resultados alcançados, torna-se importante chamar atenção ao fato de que a soja, milho e cana de açúcar foram os cultivos que aumentaram sua área com maior rapidez em 2012 e que, de 2000 a 2012, as áreas de cultura aumentaram 18,5 milhões de hectares, enquanto a área florestada da região amazônica diminuiu 19,5 milhões de hectares (FERREIRA FILHO et al., 2015). Andrade de Sá et al. (2013) encontrou efeito indireto do uso do solo decorrente da expansão da cana de açúcar no desmatamento na Amazônia Legal e também a substituição gradual da criação de gado distante das principais áreas de produção de cana de açúcar no Centro-Sul do Brasil junto à fronteira da Amazônia. A causa imediata do desmatamento na Amazônia Legal, segundo Barona et al. (2010), foi predominantemente da expansão das pastagens e não propriamente da expansão de soja. No entanto, em MT, o aumento da produção do cultivo do grão ocorreu em regiões anteriormente utilizadas para pastagem, o que pode ter deslocado a pastagem para áreas florestadas causando desmatamento. Para Gollnow e Lakes (2014), a expansão de soja no MA, TO e PI pode ter levado, adicionalmente, a processos de deslocamento ligados ao desmatamento e a conversão de ecossistemas. 
Dentro dessa perspectiva, parece plausível que as taxas positivas de retorno para pecuária na Amazônia estejam ligadas a habilidade de capturar o aumento do valor da terra que acompanham a limpeza dos terrenos e o estabelecimento da posse juntamente com a expectativa de melhorias da infraestrutura e da tendência da subida do preço do terreno devido ao aumento da demanda por commodities agrícolas (BOWMAN et al., 2012).

Dessa maneira, ao permitir que uma parte do pasto existente acomode a expansão de alimento e biocombustíveis, a intensificação dos sistemas pastoris é uma estratégia para evitar futuras perdas de vegetação nativa (MARTHA JÚNIOR et al., 2012). A recuperação de pastagens degradadas e a adoção de sistemas integrados, como a integração lavoura-pecuária ou lavoura-pecuária-floresta, mais sustentáveis do que os sistemas especializados (monocultivos) podem auxiliar no atendimento da demanda crescente por alimentos, fibras e bioenergia, sem afetar a sustentabilidade dos ecossistemas e dos agroecossistemas, proporcionando maior produção, sem a expansão das áreas de pastagem (DIAS- FILHO, 2011; VILELA et. al., 2012).

A necessidade de intensificar a produção bovina (produção anual de carne por unidade de área de pasto) pode ser satisfeita pela combinação do aumento da produtividade da pastagem e produtividade do rebanho. A produtividade das pastagens pode aumentar através de uma maior seleção de forragens, incorporação de leguminosas, pastejo rotacionado e introdução de sistemas mistos. A produtividade do rebanho pode intensificar, por exemplo, através de uma melhor seleção de raça e manejo reprodutivo (STRASSBURG et al., 2014). Todavia, os sistemas de alta produtividade requerem também maior capital e especialização para o manejo adequado (VOSTI et al,. 2001).

Os produtores só intensificam quando o retorno marginal das práticas extensivas juntamente com a abertura de novas áreas for menor do que das práticas de intensificação (KAIMOWITZ e ANGELSEN, 1998; CATTANEO, 2008). Para que as práticas intensivas ganhem escala, a transferência de tecnologia, treinamento e os serviços de concessão de credito precisam crescer ou expandir (VAN VLIET al., 2012). Deve-se levar em conta de que o capital humano leva tempo para ser aprimorado e políticas de segmentação no fortalecimento da educação e qualidade de ensino são necessárias (MARTHA JÚNIOR et al., 2012). Tais incentivos são importantes 
principalmente para as regiões Norte e Nordeste, onde a tecnologia empregada na produção regional é geralmente defasada em relação ao restante do país, com menor nível de escolaridade da mão de obra, menor capacitação empresarial e onde a maior parte dos estabelecimentos agropecuários da região não tem acesso a assistência técnica (CASTRO, 2013).

Os desafios encontrados no cenário atual da agropecuária brasileira apenas confirmam o caráter heterogêneo da agricultura no país que foi aprofundado desde o período de modernização onde a integração técnica da indústria com a agricultura se condicionou aos grandes proprietários rurais (Delgado, 2001).

Os subsídios do Programa Nacional de Fortalecimento da Agricultura Familiar (PRONAF) tem permitido ampliar as capacidades de geração de renda das populações pobres no Brasil, entretanto, a maior parte dos recursos é dirigida para o crédito de custeio, reduzindo bastante o potencial do programa em promover mudanças estruturais que poderiam alavancar de forma mais decisiva a capacidade produtiva dos pequenos produtores (BUAINAIN et al., 2014). Segundo Abramovay (2003), os subsídios talvez fossem mais bem empregados se constituídos por um sistema de transferência direta de renda para seus beneficiários associado a uma assistência técnica voltada à realização de projetos reais de desenvolvimento, revelando as capacidades adormecidas em regiões mais pobres e não à simples administração burocrática de recursos supostamente creditícios.

Políticas para reduzir os efeitos da intensificação nas mudanças dos usos de terra são necessárias, incluindo a proteção de florestas de alto valor de conservação, regulamentos ambientais sobre o desmatamento da floresta, zoneamento do uso da terra e monitoramento por satélite de novos desmatamentos (BYERLEE et al., 2012). Políticas compensatórias também podem ser instaladas para que a preservação florestal seja cada vez mais praticada, adaptadas de acordo com as diferenças entre os produtores em termos de tamanho, capital e tecnologia utilizada (FERREIRA FILHO, 2015).

O Zoneamento Agrícola de Risco Climático - Zarc, Zoneamento Ambiental ZA, Zoneamento Ecológico- Econômico - ZEE e o Zoneamento Agroecológico de Cana-de-Açúcar são instrumentos importantes de ordenação territorial e ambiental, que tem como objetivo principal incorporar a dimensão ambiental ao processo produtivo, assegurando a compatibilidade do uso da terra com a aptidão ambiental. No caso do 
Zarc, a observância às recomendações do pacote tecnológico é condição necessária para participar dos programas de seguro (Proagro, Proagro Mais e Subvenção do Seguro Rural), além do acesso a certas linhas de crédito rural oficial (BUAINAIN, 2014).

Em 2012, foi criado o Cadastro Ambiental Rural (CAR) com objetivo de integrar informações ambientais das propriedades e posses rurais, compondo base de dados para controle, monitoramento, planejamento ambiental e econômico, além do combate ao desmatamento. A partir de 2017, será obrigatório o CAR para a concessão de crédito agrícola (CAR, 2015). Esse é um passo importante, dado que os agentes financeiros, que operam as linhas de financiamento como o do Plano ABC (Agricultura de Baixo Carbono) utilizam essa informação como critério para a concessão de benefícios: para promover a redução das emissões de fases de efeito estufa oriundas das atividades agropecuárias, para reduzir o desmatamento, para aumentar a produção agropecuária em bases sustentáveis, para adequar as propriedades rurais à legislação ambiental, bem como ampliar a área de florestas cultivadas e estimular a recuperação de áreas degradadas (VIEIRA JÚNIOR et al., 2014).

Adicionalmente, em 2006 e em 2009, a moratória da soja e a moratória da carne foram implementadas respectivamente. Ambas são iniciativas que a agroindústria tomou para limitar o desflorestamento pela invasão direta de campos de soja ou de áreas de pastagem em florestas (Boucher et al., 2011; Rudorff et al.,2011). A Associação Brasileira das Indústrias de Óleos Vegetais - ABIOVE e a Associação Brasileira dos Exportadores - ANEC se comprometeram a não comercializar nem financiar a soja produzida em áreas que foram desmatadas no bioma amazônico. A Moratória respondeu ao questionamento de grupos de ambientalistas e de clientes do Brasil no exterior que passaram a promover arranjos institucionais privados destinados a gerar novas regras sustentáveis para o cultivo e comercialização da soja (ABIOVE, 2012).

Dessa maneira, a desaceleração da produção bovina e de soja no Mato Grosso apontada em 2003-2012 (Figura 19 e Figura 23) pode estar relacionada à atuação do PPCDAM e a pressão e regulação do mercado como a moratória da soja e da carne descritos anteriormente.

Os formuladores de políticas buscam tentativas para balancear o crescimento econômico com a agricultura e a conservação do meio ambiente, no entanto, devem compreender que a mudança do uso do solo é um fenômeno espacial complexo, e que as 
pressões de conversão na floresta amazônica estão relacionadas a eventos que ocorrem tanto no núcleo rural agrícola do país quanto nos mercados globais. Dessa forma, políticas triviais não funcionarão sem completa compreensão das dinâmicas subjacentes (RICHARDS et al., 2014).

Por fim, a expansão recente nas regiões Norte (RO, RR, TO e PA) e Nordeste (BA, MA e PI) indicadas nos mapas de aceleração do crescimento da produção bovina observada no período 1998- 2012 (Figura 19 e 20), juntamente com a aceleração do crescimento das produções de soja e milho no período 2003-2012 (Figura 23 e 24 e Figura 25 e 26, respectivamente), leva a questão de que as novas áreas de cultivo estão cada vez mais distantes dos principais centros consumidores (localizados nas regiões Sul e Sudeste) e dos principais portos (CASTRO, 2015). As cadeias agrícolas organizadas e de relevância internacional, com produção de escala, são as únicas capazes de superar o alto custo logístico na margem de comercialização, enquanto os pequenos agricultores e a produção agrícola não comoditizada demandam estratégias cada vez mais inovadoras para superar os gargalos logísticos e acessar a novos mercados (OLIVEIRA, 2014).

Nesse contexto tornam-se necessários projetos viáveis ao adequado escoamento da produção, promovendo a melhoria das estradas e incentivando a intermodalidade, com ampliação da oferta dos modais hidroviários e ferroviários, além de aumentar a capacidade dos portos e aperfeiçoar a cabotagem no país, para que haja um transporte eficiente de commodities agrícolas e efetivas contribuições à economia brasileira, reduzindo custos e aumentando a competitividade dos produtos agrícolas nos mercados (CAPACLE CORREA e RAMOS, 2010; PLÁ e SALIB, 2003). Segundo Bertussi e Ellery Jr (2012), o investimento na infraestrutura de transporte das regiões Norte, Nordeste e Centro-Oeste pode acelerar o crescimento econômico dessas regiões gerando aumentos na renda da população atraindo maiores investimentos e diminuindo disparidades econômicas com as regiões Sul e Sudeste do país. A geração de emprego e renda por parte do desenvolvimento da agropecuária regional também contribui para diminuir a prática de atividades ilegais na Floresta Amazônica (CASTRO, 2013). 


\section{CONSIDERAÇÕES FINAIS}

As análises obtidas na presente dissertação levaram a um maior entendimento da dinâmica espaço- temporal das produções de cana de açúcar, soja, milho e bovina, que possuem um papel de destaque no cenário agropecuário brasileiro. O estudo também serviu para prover subsídios para análises complexas que envolvem a gestão de produção e, igualmente, para gestão territorial devido às mudanças do uso do solo causadas pela substituição espacial entre as produções analisadas.

Foi possível observar que os municípios do Sul, Centro- Oeste e oeste do Nordeste apresentaram alta taxa de crescimento de produção de soja e milho durante todo o período analisado, o que reforça a importância do papel da pesquisa, crédito rural e extensão rural como os principais instrumentos que contribuíram para a tropicalização da agricultura brasileira, que em pouco tempo saiu de áreas temperadas do Sul do Brasil chegando ao sul do PI e do MA (BARROS, 2014). Tal cenário foi confirmado pelo mapa de ponto médio que indica o direcionamento de ambas as produções (soja e milho) para a porção norte do país.

A produção de cana de açúcar apresentou alta taxa de crescimento e aceleração do crescimento na parte Centro-Sul do país, adicionalmente, o mapa do ponto médio indicou o deslocamento da atividade da região Nordeste para a parte Centro-Sul, ilustrando assim a perda da participação da produção nordestina, em razão da alta eficiência e tecnificação da produção no Centro-Sul e das características climáticas, topográficas e de baixo nível tecnológico que atingem negativamente a produção no Nordeste (RICHARDS et al., 2012).

A produção bovina durante 1988-1997 e a produção de milho e cana de açúcar no período 1993-2002 apresentaram alta redução da taxa de crescimento de produção nos municípios da região Nordeste. Durante o período 1990-1998, a região nordestina passou por dois episódios do fenômeno El Niño que colaboraram para o encerramento das atividades de várias unidades produtivas agrícolas, reduzindo a produção e o número de empregos.

Além disso, foi observado no período 2003-2012 a redução da taxa de crescimento e desaceleração das produções de milho, soja e bovina nos municípios do Centro-Sul, principalmente em SP, o que vai de encontro com as evidências que grande 
parte do aumento da produção de cana de açúcar na região, causado principalmente pela entrada de carros flexfuel no mercado brasileiro em 2003, foi alcançado através da substituição de pastagens e áreas de cultivo de milho, feijão, algodão e soja.

Soma-se a essa evidência o fato de que na análise da correlação inversa entre a produção bovina e a produção de cana de açúcar, no período 2002-2010, os municípios que estavam na região Centro-Sul tiveram maior destaque. Além disso, a maioria dos municípios que apresentaram aumento da produção de cana de açúcar e diminuição da produção bovina estava nessa mesma região. O que sugere que o aumento da produção de cana de açúcar acarretou a diminuição da produção bovina no Centro-Sul.

A análise da correlação inversa entre a produção de soja e a produção bovina apontou principalmente os municípios do Centro-Oeste, Sudeste e Sul do país. Durante o período de 2003-2012, os municípios que apresentaram o aumento da produção de soja e diminuição da produção bovina estavam nessas regiões. O período 2001-2004 foi de grande dinamismo para a agricultura brasileira devido à alta de preços das commodities no mercado internacional, causados pelo aumento da demanda de importações chinesas. Assim, a soja tornou-se mais rentável o que também pode ter levado a diminuição da produção bovina nesses municípios.

Cabe destacar que, nos períodos recentes analisados nos mapas da taxa de crescimento e de aceleração do crescimento da produção bovina, foi observada alta taxa de crescimento nos municípios que fazem parte da Amazônia Legal, especialmente na porção norte do MT, oeste de RO, PA, e também no sul da AM, AP, MA. O que foi confirmado pelo mapa de ponto médio da produção que apontou que a produção bovina ao longo do tempo se deslocou para a porção noroeste do país. A recente diminuição da produção bovina no Centro-Oeste, Sul e Sudeste acarretado pelo aumento da produção de soja e cana de açúcar nessas regiões pode ter levado a produção bovina a se destacar nas porções mais ao norte do país.

Os trabalhos de Andrade de Sá et al. (2013), Barona et al. (2010), Gollnow e Lakes (2014), sugerem que o processo de expansão agrícola levou a produção bovina para áreas florestadas causando desmatamento. Dentro dessa perspectiva, são necessárias políticas para reduzir os efeitos da intensificação nas mudanças de usos de terra, incluindo práticas para intensificar a produção bovina com a utilização de sistemas integrados, como a integração lavoura-pecuária ou lavoura-pecuária- floresta, e 
regulamentos ambientais sobre o desmatamento na floresta, zoneamento do uso da terra e monitoramento por satélite de novos desmatamentos, os quais já foram comentados anteriormente.

Para que as práticas intensivas ganhem escala é importante a introdução de tecnologia, treinamento e inserção de crédito, principalmente nas regiões Norte e Nordeste que apresentam menor nível de escolaridade da mão de obra, menor capacitação empresarial e menor assistência técnica nos estabelecimentos rurais. A tradição histórica brasileira (própria das sociedades de passado escravista) que desagrega o trabalho do conhecimento persiste até hoje no meio rural. É preciso levar adiante um pacto de desenvolvimento territorial que consiste na mudança do ambiente educacional existente no meio rural (ABRAMOVAY, 2000).

O país deve ter uma política clara para aumentar a capacidade de absorção de tecnologia, que requer melhorias na extensão rural e na educação. Tais políticas precisam estar associadas entre o Governo Federal, estados e municípios, com propósito de criar capilaridades no sistema, difundindo novas técnicas e conhecimentos para chegar ao produtor (VIEIRA FILHO, 2013).

Por fim, o destaque da produção de soja e milho ao norte do Mato Grosso e oeste do Nordeste indicados nos mapas de aceleração e da produção bovina nas regiões Norte e também Nordeste apontam que são necessários investimentos na infraestrutura de transportes para acelerar o crescimento econômico das regiões Norte, Nordeste e Centro-Oeste, reduzindo custos e aumentando a competitividade das commodities agrícolas brasileiras.

Dessa forma, a partir da análise dos mapas de crescimento, de aceleração, ponto médio e da correlação inversa (entre a produção bovina e a produção de soja e entre a produção bovina e a produção de cana de açúcar) foi possível analisar de forma integrada a dinâmica das produções de cana de açúcar, soja, milho e bovina no Brasil. A análise mostrou que são complexas as causas motores do deslocamento destas produções no território brasileiro, que podem estar ligadas a razões climáticas, topográficas, de acesso ao crédito e assistência técnica, e também por questões de mercado. São necessárias políticas públicas de longo prazo que compreendam de forma integrada essas dinâmicas para impulsionar a mudança em direção a práticas 
sustentáveis de intensificação de uso do solo, levando em consideração as disparidades regionais e promovendo a ciência e a inovação na agropecuária brasileira. 


\section{REFERÊNCIA BIBLIOGRÁFICA}

ABIOVE, 2013. Moratória da soja. Disponível: http://www.abiove.org.br/site/index.php?page=moratoria-da-soja\&area=NS0zLTE= Acessado em: agosto de 2015

ABRAMOVAY, R. Finanças de proximidade e desenvolvimento territorial no semiárido brasileiro. IN: COSSIO, M.B. Estrutura agrária, mercado de trabalho e pobreza rural. cap 12. 2003.

ABRAMOVAY, R. O capital social dos territórios: repensando o desenvolvimento rural. Economia Aplicada. v.4. n.2. abril/junho de 2000.

ABRAMOVAY, R; PIKETTY,M-G. Política de crédito do programa nacional de fortalecimento da agricultura familiar (PRONAF): resultados e limites da experiência brasileira dos anos 90. Cadernos de Ciência \& Tecnologia. Brasília. v.22. n.1. p. 5366. 2005.

ANDRADE DE SÁ, S; PALMER, C; DI FALCO, S. Dynamics of indirect land-use change: empirical evidence from brazil. Journal of environmental economics and management. v. 65. p.377-393. 2013.

ARVOR, D; MEIRELLES, M; DUBREUIL,V; BÉGUÉ,A; SHIMABUKURO, Y,E. Analyzing the agricultural transition in Mato Grosso, Brazil, using satellite-derived indices. Applied Geography. v. 32. p. 702-713. 2012.

AB'SÁBER, A.N; Os domínios de natureza no Brasil: potencialidades paisagísticas. São Paulo: Atêlie Editorial, 2003.

ANP, 2014. Agência Nacional do Petróleo, Gás Natural e Biocombustíveis. Disponível em: http://www.anp.gov.br. Acessado em: Abril de 2015

BACCARIN, J.G. Sistema de produção agropecuário brasileiro: características e evolução recente /2.ed. - São Paulo: Cultura Acadêmica: Universidade Estadual Paulista, Pró-Reitoria de Graduação, 2011.

BALBINO, L.C; BARCELlOS, A,O; STONE; L.F. Marco referencial: integração lavoura-pecuária-floresta. Brasília, DF: Embrapa, 2011, p. 127.

BARROS, J.R.M. O passado no presente: a visão do economista. IN:BUAINAIN, A.M; ALVES, E; SILVEIRA, J.M; NAVARRO,Z. O mundo rural no Brasil do século 21: a formação de um novo padrão agrário e agrícola. Brasília, DF: Embrapa, 2014.

BARONA, E; RAMANKUTTY, N; HYMAN, G; COOMES, O.T. The role of pasture and soybean in deforestation of the Brazilian Amazon. Environmental Research Letters.v.5.p 1-9.2010. 
BERTUSSI, G.L; ELLERY JUNIOR, R. Infraestrutura de transporte e crescimento econômico no Brasil. Journal of Transport Literature. v.6 n.4. p. 101-132. 2012.

BIELSCHOWSKY, R. Sesenta años de la CEPAL: estructuralismo y neoestructuralismo. Revista Cepal. v.97. p. 173-194. 2009

BNDES. Commodities agrícolas: evolução recente dos preços. Informativo Técnico Seagri. n.4, agosto, 2011.

BOWMAN, M; SOARES-FILHO, B; MERRY,F; NEPSTAD, D; RODRIGUES, H; ALMEIDA, O; Persistence of cattle ranching in the Brazilian Amazon: a spatial analysis of the rationale for beef production. Land Use Policy. v. 29. p. 558-568. 2012.

BORGHI, E; BORTOLON, L; AVANZI, J.C; BORTOLON, E.S.O; UMMUS, M.E; GONTIJO NETO, M.M; COSTA, R.V. Desafios das novas fronteiras agrícolas de produção de milho e sorgo no Brasil- desafios da região MATOPIBA. IN: KARAM, D.; MAGALHÃES, P. C. Eficiência nas cadeias produtivas e abastecimento global. cap. 25, p. 263-278. 2014.

BRAY, S.C; FERREIRA, E.R; GASPAR RUAS, D.G. As políticas da agroindústria canavieira e o Proálcool no Brasil. UNESP Marília Publicações. 2000.

BRANDÃO, A.S.P; REZENDE, G.C; MARQUES, R.W.C. Crescimento agrícola no Brasil no período 1990:2004: explosão da soja e da pecuária bovina e seu impacto sobre o meio ambiente. Texto para discussão, n.1103. IPEA. 2005.

BOUCHER, D; ROQUEMORE, S; FITZHUGH. Brazil's success in reducing Deforestation. Tropical Conservation Science. v.6. n. 3. P.426-445. 2013

BULLER, L.S; BERGIER, I; ORTEGA, E; MORAES, A; BAYMA-SILVA, G; ZANETTI, M. R. Soil improvement and mitigation of greenhouse gas emissions for integrated crop- livestock systems: case study assessment in the Pantanal savanna highland, Brazil. Agricultural Systems.v.137. p.206-219. 2015.

BUAINAIN, A.M. Alguns condicionantes do novo padrão de acumulação da agricultura brasileira.IN: BUAINAIN, A.M; ALVES, E; SILVEIRA, J.M; NAVARRO,Z. O mundo rural no Brasil do século 21: a formação de um novo padrão agrário e agrícola. Brasília, DF: Embrapa, 2014.

BUAINAIN, A.M; DEDECCA, C.S. Mudanças e reiteração da heterogeneidade do mercado de trabalho agrícola. IN: GASQUES, J.G; VIEIRA FILHO, J.E.R; NAVARRO, Z. A agricultura brasileira: desempenho, desafios e perspectivas. Brasília, DF. Ipea. 298p. 2010.

BUAINAIN, A.M; SANTANA, C.A.M; SILVA, F.P; GARCIA, J.R; LOYOLA, P. O tripé da política brasileira: crédito rural, seguro e pronaf. IN: BUAINAIN, A.M; ALVES, E; SILVEIRA, J.M; NAVARRO,Z. O mundo rural no Brasil do século 21: a formação de um novo padrão agrário e agrícola. Brasília, DF: Embrapa, 2014. 
BYERLEE, A; STEVENSON, J; VILLORIA, N. Does intensification slow crop land expansion or encourage deforestation? Global Food Security.v.3. p. 92-98. 2014.

CAPACLE CORREA, V.H; RAMOS, P. A precariedade do transporte rodoviário brasileiro para o escoamento da produção de soja no centro-oeste: situação e perspectivas. Revista de Economia e Sociologia Rural. v. 48. N.2. p. 447-472. 2010

CARVALHO, J.L. Agriculture, industrialization and the macroeconomic environment in Brazil.Food Police. p. 48-57. 1991

CAR - CADASTRO AMBIENTAL RURAL. 2015. Disponível em: http://www.car.gov.br/\#/ Acessado em: Agosto de 2015

CASTRO, N. Expansão rodoviária e desenvolvimento agrícola dos cerrados. In: HELFAND,S.; REZENDE,G.C. Região e espaço no desenvolvimento agrícola brasileiro. Rio de Janeiro: Ipea, Nemesis/Pronex. p.213-243. 2003

CASTRO, C.N. A agropecuária na região norte: oportunidades e limitações ao desenvolvimento. Texto para discussão 1836. IPEA. 2013.

CASTRO, C.N. O agronegócio e os desafios do financiamento da infraestrutura de transportes no brasil. Texto para discussão 2074. IPEA. 2015.

CASTRO, S.S; ABDALA,K; SILVA A.A; BORGES, V.M.S. A expansão da cana de açúcar no cerrado e no estado de Goiás: elementos para uma análise especial do processo. Boletim Goiano de Geografia, Goiânia, GO, v.30, n.1, 2010.

CATTANEO, A. Regional comparative advantage, location of agriculture, and deforestation in Brazil. Journal of Sustainable Forestry. v.27. p.25-42. 2008.

CEPAL - Comision Economica para America Latina y el Caribe. Estudio economico de la America Latina 1950. Santiago de Chile. 1951a

CEPAL - Comision Economica para America Latina y el Caribe. Estudio econômico de America Latina 1949. Santiago de Chile. 1951b

CREMONEZ, P.A; FEROLDI, M; NADALETI, W.C; ROSSI,E; FEIDEN,A; CAMARGO,M.P; CREMONEZ, F,E; KLAJN, F.F. Biodiesel production in Brazil: Current scenario and perspectives. Renewable and Sustainable Energy Reviews. v.42. p.415-428. 2015.

CONTINI, E. Dinâmica das mudanças e transformações da agricultura brasileira. IN: OTERO, M.R; OLIVEIRA, M.M; TIBÚRCIO, B.A; RAMIREZ, A.R. Agricultura e desenvolvimento rural sustentável: desafios da cooperação técnica internacional. Brasília, DF. IICA. 443p. 2015.

DELGADO, G.C. Expansão e modernização do setor agropecuário no pós-guerra: um estudo da reflexão agrária. Estudos Avançados.v.15. n.43. 2001. 
DIAS-FILHO, M.B. Os desafios da produção animal em pastagens na fronteira agrícola brasileira. Revista Brasileira de Zootecnia. v.40. p.243-252. 2011.

DICK,M; ABREU DA SILVA,M; DEWES, H. Mitigation of environmental impacts of beef cattle production in southern Brazil - evaluation using farm-based life cycle assessment. Journal of Cleaner Production.v.87 p.58-67. 2015.

FAO, 2011.Faostat by country/region. Disponível em: http://faostat3.fao.org/browse/area/21/E Acessado em: Janeiro de 2015.

FAO- FOOD AND AGRICULTURE ORGANIZATION OF THE UNITED NATIONS. Faostat: Rankings - Food and agricultural commodities production/ $\begin{array}{llll}\text { Countries by } & \text { commodities. } & \text { Disponível }\end{array}$ em:http://faostat3.fao.org/browse/rankings/countries_by_commodity/E Acessado em: Janeiro de 2015.

FERREIRA FILHO, J.B.S; RIBERA, L; HORRIDGE, M. Deforestation control and agricultural supply in Brazil. American Journal of Agricultural Economics. v.97 n.2 p. 589-601. 2015.

FIGUEIREDO, E.V.C; CONTINI, E. China: gigante também na agricultura. Revista de Politica Agrícola. Brasília, DF, ano 22, n.2, p. 5-29, abri./maio/jun. 2013.

GASQUES, J.G; VILLA VERDE, C.M. Crescimento da agricultura brasileira e política agrícola nos anos oitenta. IPEA- Instituto de Pesquisa Econômica Aplicada. Brasília. p. 5-15. 1990.

GOLLNOW, F; LAKES, T. Policy change, land use, and agriculture: The case of soy production and cattle ranching in Brazil, 2001 e 2012. Applied Geography. v.55. p. 203-211. 2014.

HAGUENAUER, L; DIAS BAHIA, L; FURTADO DE CASTRO, P. RIBEIRO, M.B. Evolução das cadeias produtivas brasileiras na década de 90. IPEA- Instituto de Pesquisa Aplicada Econômica. Brasília. p.5-50. 2001

HARVEY, M. PILGRIM, S. The new competition for land: Food, energy, and climate change. Food Policy. v.36. p. 40-51. 2011.

HOFFMANN, R; KAGEYAMA, A.A. Modernização da agricultura e distribuição de renda no Brasil. Pesquisa e Planejamento Econômico. Rio de Janeiro. v.15 n. 1. P.171-208. 1985.

HOMMA, A.K; MENEZES, A. J.E; MORAES, A.J.G. Dinâmica econômica, tecnologia e pequena produção: o caso da Amazônia. IN:BUAINAIN, A.M; ALVES, E; SILVEIRA, J.M; NAVARRO,Z. O mundo rural no Brasil do século 21: a formação de um novo padrão agrário e agrícola. Brasília, DF: Embrapa, 2014. 
IBGE - INSTITUTO BRASILEIRO DE GEOGRAFIA E ESTATISTICA. Sistema IBGE de Recuperação Automática - SIDRA. 2012. Disponível em: http://www.sidra.ibge.gov.br/bda/agric/default.asp?t=4\&z=t\&o=11\&u1=1\&u2=1\&u3=1 $\& u 4=1 \& u 5=1 \& u 6=1$ Acessado em: Abril de 2015.

IBGE - INSTITUTO BRASILEIRO DE GEOGRAFIA E ESTATÍSTICA. Censo Agropecuário 2006. Rio de Janeiro: IBGE, 2009. p.775.

IBGE - INSTITUTO BRASILEIRO DE GEOGRAFIA E ESTATISTICA. Contas Regionais do Brasil 2010. Contas Nacionais. Rio de Janeiro: IBGE, 2012a. p. 55.

IBGE - INSTITUTO BRASILEIRO DE GEOGRAFIA E ESTATISTICA. Produto interno Bruto dos Municípios- 2010. Rio de Janeiro: IBGE, 2012b. p.105.

IBGE - INSTITUTO BRASILEIRO DE GEOGRAFIA E ESTATISTICA. Produção Agrícola Municipal- 2011. v.38. 2011

IBGE - INSTITUTO BRASILEIRO DE GEOGRAFIA E ESTATISTICA. Mapa de Biomas do Brasil . Rio de Janeiro: IBGE, 2004.

IBGE - INSTITUTO BRASILEIRO DE GEOGRAFIA E ESTATISTICA. Síntese de Indicadores 2012. Rio de Janeiro: IBGE, 2013. p. 272.

KAIMOWITZ, D; ANGELSEN, A. Economic Models of Tropical Deforestation: a review. Center for International Forestry Research. 139p. 1998

KOHLHEPP, G. Análise da situação da produção de etanol e biodiesel no Brasil. Estudos Avançados. V.24. n. 68. 2010.

KOHLHEPP,G; BLUMENSCHEIN,M. Brasileiros sulistas como atores da transformação rural no centro- oeste brasileiro: o caso de Mato Grosso. Revista Território.

LOURENZANI, W.L; CALDAS, M.M. Mudanças no uso da terra decorrentes da expansão da cultura de cana de açúcar na região oeste do estado de São Paulo. Ciência Rural. v.44. n. 11. P. 1980-1987. novembro. 2014

MANN, M,L; KAUFMANN, R, K; BAUER, D,M; GOPAL, S; NOMACK,M; WOMACK, J,Y; SULLIVAN,K; SOARES-FILHO,B,S. Pasture conversion and competitive cattle rents in the Amazon. Ecological Economics.v.97.p.182-190. 2014.

MARTHA JÚNIOR, G, B; ALVES, E; CONTINI, E. Land-saving approaches and beef production growth in Brazil. Agricultural Systems.v.110. p. 173-177. 2012.

MARTINELLI, L.A; ROSAMOND, N; VITOUSEK, P.M; MOUTINHO, P. Agriculture in Brazil impacts, costs, and opportunities for a sustainable future. Geoforum .v.2. p. 431-438. 2010. 
MARTINELLI, L.A; GARRETT, R; FERRAZ, S; ROSAMOND, N. Sugar and ethanol production as a rural development strategy in Brazil: Evidence from the state of São Paulo. Agricultural Systems. v.104. p. 419-428. 2011.

MARTINEZ, S.H; EJICK, J.V; CUNHA, M.P; GUILHOTO, J.J.M; WALTER, A. FAAIJ,A. Analysis of socio-economic impacts of sustainable sugarcane-ethanol production by means of inter-regional input-output analysis: demonstrated for northeast Brazil. Renewable and Sustainable Energy Reviews. n.28. p.290-316. 2013.

MELO, F. H. O crescimento agrícola brasileiro dos anos 80 e as perspectivas para os anos 90. Revista de economia política. São Paulo. v. 10. n. 3. p. 23-30. 1990.

MELO, J.C. O fenômeno el niño e as secas do nordeste do Brasil. Raízes. ano.18. n.20. p.13-21. 1999.

MELO, F.H; PELIN, E. As soluções energéticas e a economia brasileira. Hucitec. 184p. 1984

MERTEN, G,.H; MINELLA, J.P.G; MORO,M; MAIER,C. Expansion of brazilian agricultural territory: changes in land use. Global change: challenges for soil management. P.13-21. 2010.

MMA, 2013. PPCDAM - Plano de ação para a Amazônia. Disponível em: http://www.mma.gov.br/florestas/controle-e-preven\%C3\%A7\%C3\%A3o-dodesmatamento/plano-de-a\%C3\%A7\%C3\%A3o-para-amaz\%C3\%B4nia-ppcdam Acessado em: Agosto de 2015.

MUELLER,C,C. Dinâmica, condicionantes e impactos socioambientais da evolução da fronteira agrícola no Brasil. Revista de Administração Pública. v. 26. p.64-87. 1992.

MUELLER, C.C. Dinâmica, condicionantes e impactos socioambientais da evolução da fronteira agrícola no Brasil. Revista de Administração Pública. v.26 n.3 p.64-87. 1992.

MUELLER, C.C; MUELLER, B. The evolution of agriculture and land reform in Brazil, 1950 -2006. Paper prepared for the Conference in honor of Werner Baer, University of Illinois. P.1-35. 2006.

MUELLER, C.C; MARTINE, G. Modernização da agropecuária, emprego agrícola e êxodo rural no Brasil - A década de 1980. Revista de Economia Política. v.17. n.3. p.85-104. 1997.

MUELLER, C.C. Fronteira, frentes e a evolução recente da ocupação da força de trabalho rural no Centro- Oeste. Pesquisa e Planejamento Econômico. Rio de Janeiro. v.13. n.2. p.619-660. 1983. 
MUELLER, B; ALSTON, L; LIBECAP,G. D; SCHNEIDER, R. Land, property rights and privatization in Brazil. The Quaterly Review of Economics and Finance.v.34.p.261-280. 1994.

MONTENEGRO, S; RAGAB, R. Impact of possible climate and land use changes in the semi-arid regions: a case study from north eastern Brazil. Journal of Hydrology. p. 55-68. 2012.

NEPSTAD, D.C; STICKLER, C.M; ALMEIRA, O.T. Globalization of the amazon soy and beef industries: opportunities for conservation. Conservation Biology. v.20. n. 6. p.1595-1603. 2006.

OLIVEIRA, A.L.R. A logística do agronegócio: para além do '’apagão logístico'. IN: BUAINAIN, A.M; ALVES, E; SILVEIRA, J.M; NAVARRO,Z. O mundo rural no Brasil do século 21: a formação de um novo padrão agrário e agrícola. Brasília, DF: Embrapa, 2014.

OVERBECK, G.E; MULLER,S.C; FIDELIS,A; PFADENHAUER,J; PILLAR,V.D; BLANCO,C.C; BOLDRINI, I.I; BOTH,R; FORNECK, E.D. Brazil's neglected biome: the south brazilian campos. Perspectives in Plant Ecology, Evolution and Systematics. v.9. p.101-116. 2007.

PLÁ, J.V.J.A; SALIB, S. Infra-estrutura de transporte e potencialidade agrícola do brasil. Indicadores Econômicos FEE. v.31. n.3. p.119-134. 2003

PREBISCH, R. Problemas teóricos y practicos del crecimiento econômico. Santiago de Chile. Comision Economica para America Latina y el Caribe- CEPAL. 90 p. 1973

PRATES, R.C; BACHA,C.J.C. Os processos de desenvolvimento e desmatamento da Amazônia. Economia e Sociedade. Campinas. v.20. n. 3. P.601-636. 2011.

PEREIRA, P.A.A; MARTHA JUNIOR, G.B; SANTANA, C.A.M; ALVES, E. The Development of brazilian agriculture, future technological challenges and opportunities. IN: MARTHA JUNIOR, G.B; FEIRREIRA FILHO, J.B.S. Brazilian agriculture: development and changes. Brasília, DF. Embrapa. 160p. 2012.

PNUD - Programa das Nações Unidas para o Desenvolvimento. Atlas do Desenvolvimento Humano. Disponível em: http://www.atlasbrasil.org.br/2013/ Acessado em: Abril de 2015.

PROCANA. Anuário de cana 2011 - Brazilian sugar and etanol guide. Ribeirão Preto. 456p. 2012.

RADA, N. Acessing Brazil's Cerrado agricultural miracle. Food Policy.v.38.p.146-155. 2013. 
RICHARDS, P.D; WLAKER, R.T; ARIMA, E.Y. Spatially complex land change: the indirect effect of brazil's agricultural sector on land use in amazonia. Global Environmental Change. v 29. p.1-9. 2014

RUDORFF, B.F.T; AGUIAR, D.A; SILVA, W.F; SUGAWARA, L.M; ADAMI, M; MOREIRA, M.A. Studies on the rapid expansion of sugarcane for ethanol production in São Paulo State (Brazil) using Landsat Data. Remote Sensing. v.2. n.4. p.1057-1076. 2010.

RUDORFF, B.F.T; ADAMI, M; AGUIAR,D.A; MOREIRA, M.A; MELLO, M.P; FABIANI, L; AMARAL, D.F; PIRES, B.M. The soy moratorium in the amazon biome monitored by remote sensing images. Remote Sensing. v.3. p. 185-202. 2011

SCHEFFLER, R; NEILL,C; KRUSCHE, A.V; ELSENBEER, H. Soil hydraulic response to land-use change associated with the recent soybean expansion at the Amazon agricultural frontier. Agriculture, Ecosystems and Environment.v.144. p.281-289. 2011.

SCISÚ, A.B; LIMA, J.P.R. Fronteiras agrícolas no Brasil: a lógica de sua ocupação recente. Nova Economia. v.10. n.1 p.109-138. 2000.

SILVA, A.G; COSTA, F.B. Os estabelecimentos rurais de menor porte econômico do Semiárido nordestino frente às novas tendências da agropecuária brasileira. IN:BUAINAIN, A.M; ALVES, E; SILVEIRA, J.M; NAVARRO,Z. O mundo rural no Brasil do século 21: a formação de um novo padrão agrário e agrícola. Brasília, DF: Embrapa, 2014.

SHIKIDA, P.F.A. Evolução e fases da agroindústria canavieira no Brasil. Revista de Política Agrícola. ano. 23. n.4. out./nov./dez. p. 43-57. 2014.

SHIKIDA, P.F.A; BACHA,C.J.C. Evolução da agroindústria canavieira brasileira de 1975 a 1995. Revista Brasileira de Economia. Rio de Janeiro. v.53. n.1 p.69-89. 1999.

SUDENE. Agregados Econômicos Regionais: Nordeste do Brasil. 1965-1998. Recife, 1999. Boletim Conjuntural - Nordeste do Brasil. n. 7. 2000.

SUZIGAN,W. Industrialização e política econômica: uma interpretação em perspectiva histórica. Pesquisa e Planejamento Econômico. v.2. p.433-474. 1975.

STRASSBURG, B.B.N; LATAWIEC, A.E; BARIONI, L.G; NOBRE, C.A; SILVA, V.P; VALENTIM, J. F, VIANNA, M; ASSAD, E.D. When enough should be enough: improving the use of current agricultural lands could meet production demands and spare natural habitats in Brazil. Global Environmental Change. v. 28. p.84-97. 2014

SZMECSÁNYI, T; MOREIRA, E.P. O desenvolvimento da agroindústria canavieira do Brasil desde a segunda guerra mundial. Estudos Avançados. v.11. n.5. p.59-79. 1991. 
USDA. USDA Foreign Agricultural Service. 2012. Disponível em: http//:apps.fas.usda.gov/psdonline Acessado em: Janeiro de 2015.

VAN VLIET, N; MERTZ, O; HEINIMANN, A; LONGANKE, T; PASCUAL, U; SCHMOOK, B; ADAMS, C; SCHIMIDT-VOGT, D; MESSERLI, P; LEISZ, S; CASTELLA, J.C; JORGENSEN, L; BIRCH- THOMSEN, T; HETT, C; BECHBRUUN, T; ICKOWITZ, A; CHI VU, K; YASUYUKI,K; FOX, J; PADOCH, C; DRESSLER, W; ZIEGLER, A,D. Trends, drivers and impacts of changes in swidden cultivation in tropical forest-agriculture frontiers: a global assessment. Global Environmental Change. v.22. n.2. p. 418-429. 2012.

VERBUG, R; ROFRIGUES FILHO, S; LINDOSO, D; DEBORTOLI, N; LITRE,G; BURSZTYN, M. The impact of commodity price and conservation Policy scenarios on Deforestation and agricultural land use in a frontier area within the amazon. Land Use Policy. v.37. p.14-26. 2014

VIEIRA FILHO, J.E.R. Transformação histórica e padrões tecnológicos da agricultura brasileira. IN:BUAINAIN, A.M; ALVES, E; SILVEIRA, J.M; NAVARRO,Z. O mundo rural no Brasil do século 21: a formação de um novo padrão agrário e agrícola. Brasília, DF: Embrapa, 2014.

VIEIRA FILHO, J.E.R. Heterogeneidad estructural de la agricultura familiar em el Brasil. Revista Cepal. N.111. Deciembre. 2013.

VIEIRA JUNIOR, P.A; FIGUEIREDO, E.V.C; REIS, J.C. Alcance e limites da agricultura para o desenvolvimento regional: o caso do Mato Grosso. IN: BUAINAIN, A.M; ALVES, E; SILVEIRA, J.M; NAVARRO,Z. O mundo rural no Brasil do século 21: a formação de um novo padrão agrário e agrícola. Brasília, DF: Embrapa, 2014.

VILLANOVA, J.A. Panorama estrutural do segmento sucroalcooleiro. Agroanalysis. v.15. n.3. p.8-12. 1995.

VILELA, L; MARTHA JUNIOR, G.B; MARCHAO, R.L. Integração lavourapecuária-floresta: alternativa para intensificação do uso da terra. Revista UFG. n.13. ano. 13. 2012.

VOSTI, S.A; CARPENTIER, C.L; WITCOVER, J; VALENTIM, J.F. Intensified smallscale livestock Brazilian Amazon. In: ANGELSEN, A., KAIMOWITZ, D. Agricultural Technologies and Tropical Deforestation. pp. 113-133. 2001 